
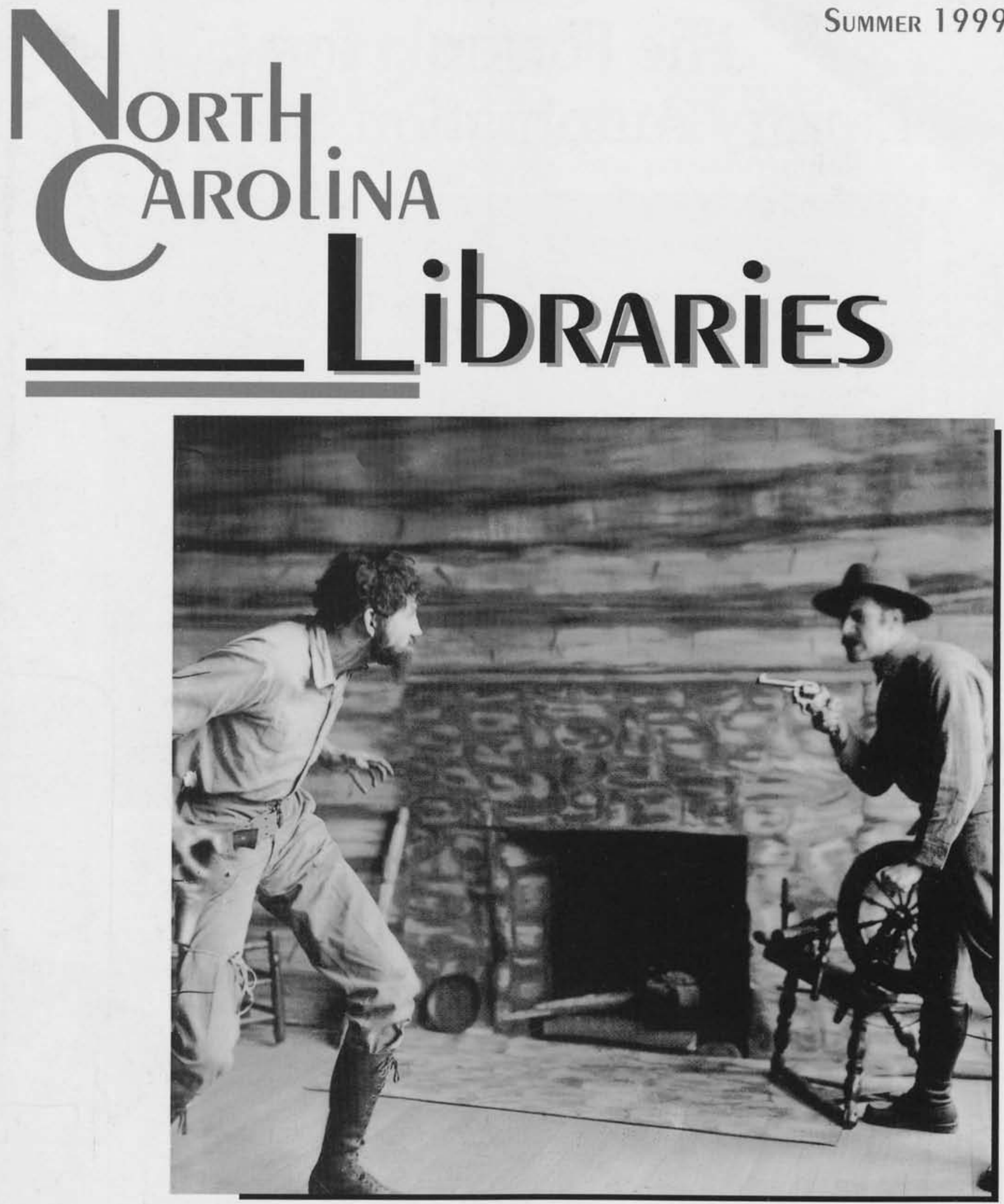

One of North Carolina's best known creative writers, Thomas Wolfe (left),

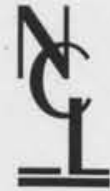
plays the title role of outlaw Buck Gavin in his play, The Return of Buck Gavin, produced by the Carolina Playmakers in March 1919 when Wolfe was a junior at the University of North Carolina. Frederick J. Cohn (right) is the Sheriff.

North Carolina Writers 


\section{The Formula for Library Automation Success}

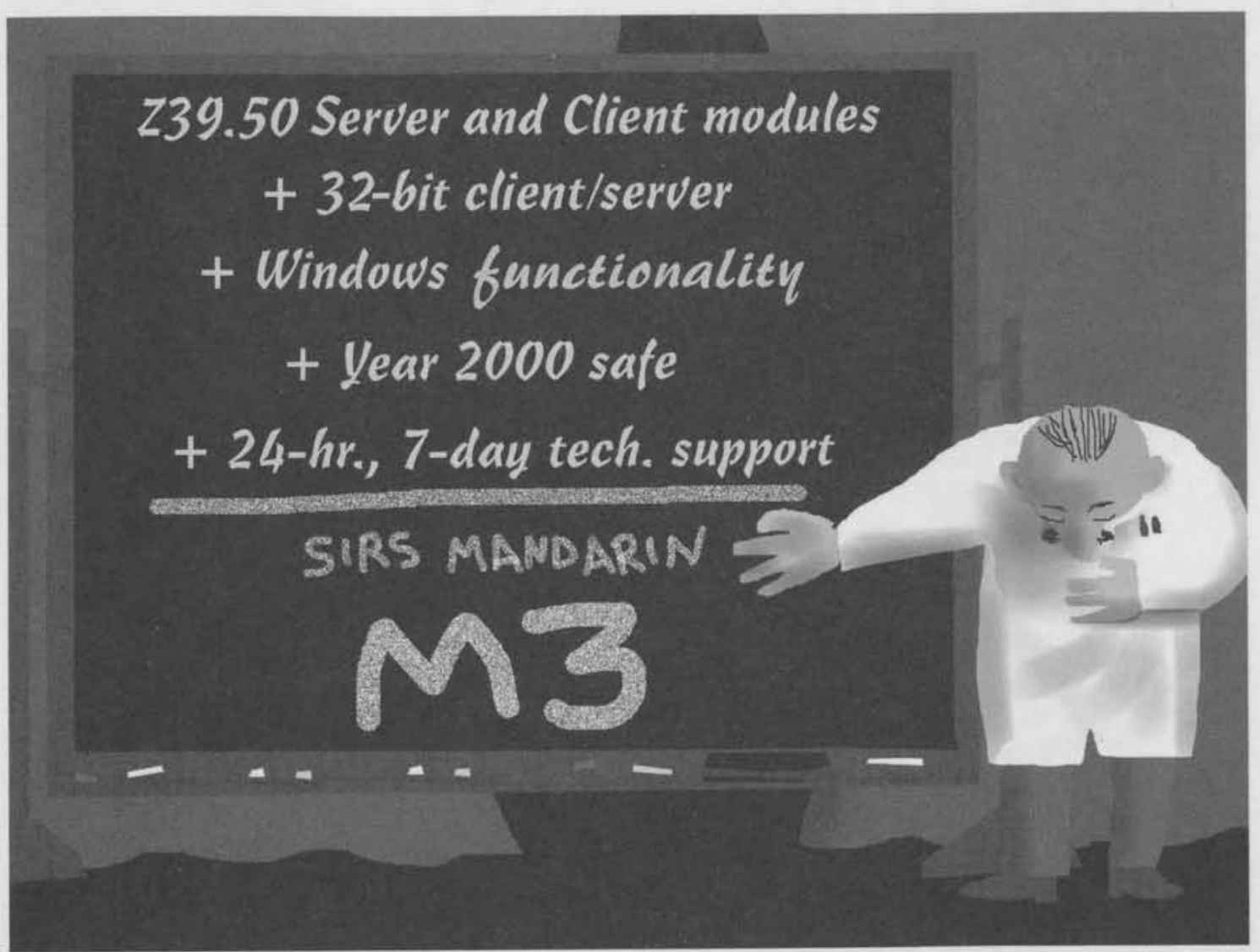

We wiped the slate clean and built a Windows ${ }^{\circledR}$ NT library automation system that adds up. M3 features the latest technology - Z39.50 (version 3); 32-bit client/server; a true MARC record engine; year 2000 compliancy; plus flexibility, scaleability and unsurpassed technical support - all at an affordable price. SIRS Mandarin $\mathrm{M}^{\mathrm{TM}}$ equals the formula for library automation success.

To learn more about SIRS Mandarin M3, speak with a library automation specialist today at 1-800-232-SIRS or e-mail mandarin@sirs.com.

\section{GIRS MANDARIN}




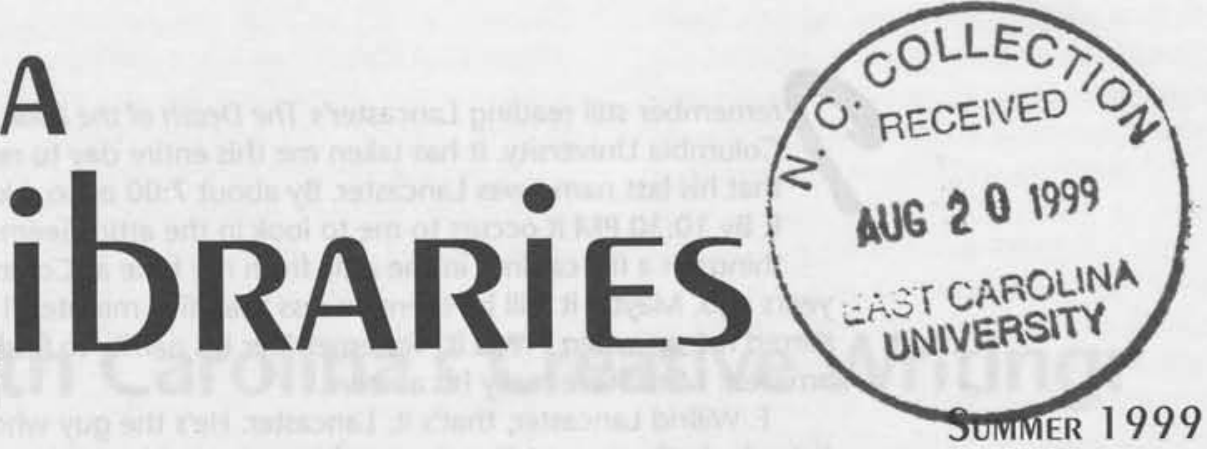

North Carolina Writers

Alice Cotten, Guest Editor

49 Collecting North Carolina's Creative Writing: One Librarian's Guide, Eileen McGrath

53 A Noble Tradition: Creative Writing at UNCG, William K. Finley

57 Writers and Libraries: A Symbiotic Partnership, Jinnie Y. Davis

62 Backyard Treasure: North Carolina Authors of Books for Children and Young Adults, Ruth Moose

64 North Carolina's Award-Winning Creative Writers

66 Little Magazines in North Carolina

70 A Field Guide to Writers in North Carolina and the South, Dorothy D. Hodder

\section{FEATURES}

48 From the President

63 About the Authors

72 Lagniappe: And What About Thomas Wolfe?, Alice Cotten

74 Wired to the World: North Carolina Authors, Ralph Lee Scott

76 North Carolina Books

83 In View Of...

84 Between Us: Whither State Documents?, Maurice C. York

85 NCLA Minutes

Advertisers: Broadfoot's, 68 Brodart, 75 Checkpoint, 82 Current Editions, 73 Davidson Titles, 87 Ebsco, 79 Mumford Books, 69 Quality Books, 81 SIRS, front cove UNC Press, back cover
Cover: This photo, recently acquired, has not previously been published. Photo courtesy of the North Carolina Collection, University of North Carolina Library at Chapel Hill.

Norih Carolina Libraries is the official publication of the North Carolina Library Association. Art direction and design by Pat Weathersbee of TeamMedia, Greenville, NC. 


\section{From the President}

Beverley Gass, President

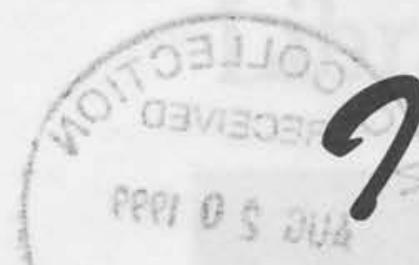

remember still reading Lancaster's The Death of the Book in 1985-86 while I was a doctoral student at

Columbia University. It has taken me this entire day to recall his name. About 6:00 PM, it came to me

that his last name was Lancaster. By about 7:00 or so, I knew that his first name began with the letter F. By 10:30 PM it occurs to me to look in the attic. Seems like I recall having filed away notes and things in a file cabinet in the attic from my time at Columbia in pursuit of the doctorate nearly 13

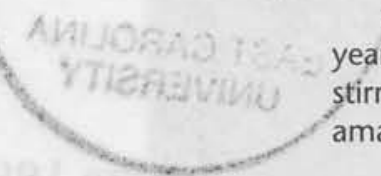
years ago. Maybe it will be there. In less than five minutes, I find it. I am stunned. It must have really stirred me up when I read it. To remember his name, to find the article, to even have kept it. I am pretty amazed. Must have really hit a nerve.

F. Wilfrid Lancaster, that's it. Lancaster. He's the guy who talked about the paperless society and questioned whether or not libraries would be needed in an electronic world. He thought that the profession (of librarianship) had its head in the sand if it continued to ignore this inevitable reality. His ideas haunted me. Could it be that I was spending all this energy working on a doctorate in library science only to have the whole darn profession disappear? Could he possibly be right? He was futuristic, even shocking.

It's accurate for me to say that Lancaster's ideas and what they might mean for libraries are ones that I have carried with me since first hearing them. It's almost been my mantra: prove him wrong, prove him wrong. I was reminded of Lancaster's predictions again last summer during ALA and the ACRL President's Program when North Carolina's own John Ulmschneider spoke of the future of the book. Another flash recall about what Lancaster said occurred again two months ago when Kem Ellis described his investigations into e-books and what this might mean for the services his public library might deliver. I was again reminded of the Lancaster prediction.

And then, it hit right here at home: the vortex of that intellectual storm has touched down right here at GTCC. Only two days ago, Technical Services Librarian Don Forbes told me that he had set counters on our library workstations to see what electronic resources were used most. Would it be NC LIVE, SIRS, LaW Desk, the library's catalog, the Internet, or some other electronic resource? I'm afraid that Don's prediction that the least used item at the workstation will be our library's catalog may be correct. Apparently, Lancaster's predictions that have haunted me for 13 years are more accurate than I feared. Now I still do not believe that libraries will disappear during my career, and they may continue for a long time to come. But, I still worry.

I worry, too, about Intellectual Freedom and First Amendment rights and Internet filters and North Carolina Senate Bill 907. We've developed Internet Use Policies for our library. We don't worry too much about challenges to our resources or our access to the Internet here in our library. We're small; we're in the cloistered environment of academe. Yeah, right. Is it not enough to worry that Lancaster might still be right? Apparently not.

For today, right here at Guilford Technical Community College, it hits. The memo arrives addressed to Community College Presidents with this ominous disclaimer attached: Please note that while this report is not listed in the Annual Reporting Plan, we must respond to this Legislative request. Must respond? Respond about what? Respond to a survey designed to collect data about the impact and costs of adhering to Senate Bill 907 should it pass. Holy smoke. It asks about our policies concerning authorized or unauthorized access to the Internet by persons under the age of 18 . It asks for how we supervise, monitor, make disclaimers for persons under 18. It asks how much it will cost us to use filtering software. Let us all hope that by the time this column appears in the next issue of North Carolina Libraries, the whole mess about Senate Bill 907 will have been swept away with some of the other debris of dead North Carolina Senate bills.

But that's not all I'm worried about. I'm really worried that Gene, Dr. Intellectual Freedom, Lanier is retiring. Late this afternoon, Gene completed the wording of a cover memo to accompany the proposed statement as it is distributed to Executive Board members. What will become of us? Who among us is prepared to take his place? Let us all hope, again, that by the time this column appears in print, NCLA will have adopted a statement on Internet access and filters.

I'm really worried, too, about what it must be like to be Jerry Thrasher, Director of the Cumberland County Public Library, and to have to wage his nearly never-ending defense of the principles of Intellectual Freedom and the role of library in the community.

Holy, holy smoke. All these worries in just one short week. I worried all day about these things. And then I worried that a colleague of mine told me today that I worry too much. Well, bah humbug, someone must worry about these things. Please, let these worries, though, be just another few of those several million things out there that I worry about all the time. And, please, give us all the strength to continue to wage the battles for libraries and Intellectual Freedom. May we find the way through these things. May the strong and brave among us be stronger and braver still. 


\title{
Collecting North Carolina's Creative Writing: One Librarian's Guide
}

\author{
by Eileen McGrath
}

W

hen I moved to North Carolina in 1984, I was familiar with twentieth-century North Carolina history and, while I had read some twentieth-century Southern literature,

I had only the slightest acquaintance with North Carolina authors. That changed when I accepted a position as a cataloger in the North Carolina Collection at the University of North Carolina at Chapel Hill. These novels, children's books, science fiction, romances, poetry, short story collections, and multi-genre, multi-author collections rolled into the cataloging work room week after week. I began to notice announcements in the local newspapers and periodicals about author readings, and I started to read reviews of North Carolina books in local and national publications. Before long, much of my professional and leisure time was absorbed by North Carolina literature. My interest must have been obivious because in 1994, I was given formal responsibility for collection development for the state's premier collection of North Caroliniana, the North Carolina Collection in Wilson Library. Because there is an enthusiasm for North Carolina creative writing among the staff of the collection, I get lots of help. Coworkers leave me articles from newspapers, pages from publishers' catalogs, printouts from Web sites, and notes about new or forthcoming books. I need (and have) a special in-box on my desk just for acquisitions ideas.

\section{The Contemporary Literary Landscape}

Tony Abbott, Alice Adams, Lavonne Adams, Sheila Kay Adams, Betty Adcock, Alex Albright, Annette Allen, Schandra Alston, A. R. Ammons, Maya Angelou, James Applewhite, Daphne Athas, Laura Argiri, Ellyn Bache, Margaret Booth Baddour, Robert Bain, Sharlene Baker, Mignon Ballard, Nigel Barnes, Wilton Barnhardt, Gerald Barrax, Robert Bateman, Joseph Bathani, Ronald Bayes, Jeffery Beam, Maudy Benz, Doris Betts, Helen Bevington, Will Blythe, Elizabeth Bolton, Earl S. Braggs, Lilian Jackson Braun, Sue Ellen Bridgers, Bill Brittain, Grey Brown, Linda Beatrice Brown, Dixie Browning, Elizabeth Brownrigg, Sally Buckner, Betsy Byars, Kathryn Stripling Byer. The North Carolina literary scene is a mighty crowded place. The list of creative writers in or from the Tar Heel State doesn't peter out as one goes through the alphabet: John York, Marly Youmans, Barbara Younger, Ila Yount, John Young, Lee Zacharias, Hugh Zachary, Robert Zimmerman, Isabel Zuber. It seems to me that North Carolina has more creative writers than any other state, except New York. This is, of course, difficult to prove.

In a recent article in the Spectator, Sally Buckner (herself a poet and anthologist) wrote that she could think of sixty fiction writers, twenty-eight poets, six dramatists, and eighteen authors of books for children and young adults in the Triangle area. ${ }^{1}$ That's over one hundred published authors in just one part of the state. Nor does this number include the many writers whose works have yet to see print, or whose works have appeared only in periodicals. For the state as a whole, one approximation might be based on the membership $(1,800)$ of the North Carolina Writers' Network. Each issue of its newsletter, The Writers' Network News, lists the names and residences of new members. If those listed in the November/December 1998 and January/February 1999 issues reflect the membership as a whole, then $90 \%$ (approximately 1,600 ) of their members are North Carolina residents. Even though some members may be librarians, nonfiction writers, editors, and publishing industry workers, I think that number is impressive. How does this compare to other states? In population North Carolina now ranks eleventh among the states; Georgia is the tenth most populous state, Virginia is the twelfth. The geographical index in Who's Who in Writers, Editors \& Poets: United States \& Canada, 1995-1996 edition lists 120 writers with Georgia residences, 177 with North Carolina, and 207 with Virginia. ${ }^{2}$ This would imply that our numbers are not extraordinary for our size, but I think that the case can be made that the Washington, D.C. sub- 
urbs skew the numbers for Virginia.

Another way to measure the magnitude of the literary scene is to look at publications. Each year the North Carolina Historical Review prints a bibliography of published, book-length North Caroliniana, arranged by general categories. ${ }^{3}$ According to the bibliographies appearing from 1988-1997, Tar Heel authors published 374 books of poetry during those ten years. Eight hundred forty-nine works of fiction with a North Carolina setting or by a North Carolina author were published in that same period. Moreover the average annual number of North Carolina fiction works has been increasing, from 67 (1988-1992) to 102 (1993-1997). Here is numerical confirmation of what many of us have thought: more North Carolina fiction writers are getting published, and writers elsewhere are finding North Carolina to be an interesting setting.

Within this crowded literary scene, all ages are represented. Writers who began their careers in the 1950s and 1960 s are still publishing. They have been joined by at least two newer generations of writers, many of whom learned their craft in courses taught by members of the older generation. The productive senior generation includes such writers as Doris Betts, Fred Chappell, and Reynolds Price. Betts published two well-received novels in the 1990s. In the same decade, Chappell, now the state's poet laureate, published nine books and chapbooks, and Price published an astounding sixteen volumes of poetry, fiction, drama, and religious meditations.

These individuals may be among the state's best known writers, but they are not exceptional in their ability to remain productive through a long career. Each year four literary competitions are sponsored by the North Carolina Literary and Historical Association in cooperation with several other cultural groups. ${ }^{4}$ The nominees for those awards are listed in the September issue of Carolina Comments..$^{5}$ The list of nominees for the Sir Walter Raleigh Award, given for the best work of fiction, and the Roanoke-Chowan Award, given for poetry, includes familiar names: Fred Chappell, Charles Edward Eaton, Elizabeth Daniels Squire (Sir Walter Raleigh Award, 1990); James Applewhite, Ronald Bayes, Fred Chappell, Lenard D. Moore (Roanoke-Chowan Award, 1993); Maya Angelou, Charles Edward Eaton, Marie Gilbert, Peter Makuck, Robert Watson (Roanoke-Chowan Award, 1995); Kathryn Stripling Byer, Michael
Chitwood, Tim McLaurin, Shelby Stephenson (Roanoke-Chowan Award, 1998). These well-established and midcareer authors are joined by new writers. Competing for the 1990 Sir Walter Raleigh Award against the luminaries mentioned above was Allan Gurganus's first novel, Oldest Living Confederate Widow Tells All. The newcomer won.

Reading the list of literary award nominees in back issues of Carolina Comments is one of the best ways to gain an appreciation for the wealth of writing talent in this state. Through these lists one can see the emergence and development of new talents such as Clyde Edgerton and Kaye Gibbons. Clyde Edgerton's first novel, Raney, was nominated for the Sir Walter Raleigh Award in 1985. Later books by Edgerton were nominated in 1987, 1989, 1991, 1993, and 1998; he received the 1998 award for his novel Where Trouble Sleeps. Kaye Gibbons's first book, Ellen Foster, was nominated in 1987; subsequent books were nominated in 1989, 1991, and 1998. This year Gibbons received the state's highest civilian honor, the North Carolina Award, for her contributions to literature.

Another phenomenon that one can see by reading the "North Carolina Bibliography" in the North Carolina Historical Review or the list of nominees in Carolina Comments is that many North Carolina writers are not limited to one genre. The state's poet laureate, Fred Chappell, has published nine books of fiction. Jim Grimsley came to wide public view with his novels Dream Boy, My Drowning, and Winter Birds; but play writing has been his primary focus for much of his career. It is hard to say whether Reynolds Price is better known as a poet or a novelist, or whether Maya Angelou is better known for her poetry or her autobiographical works. Several other poets have produced affecting memoirs, including Alan Shapiro whose The Last Happy Occasion and Vigil were published a few years ago, and Michael Chitwood whose autobiographical commentaries often can be heard on WUNC-FM.

\section{Collection Development Decisions}

When such a rich and diverse literary field meets the reality of the library budget, librarians have to make choices. Each library must define for itself the term "North Carolina literature." Is it solely the literary creation of North Carolinians, or can it include works set in North Carolina, but written by residents of other places? In the North Carolina Collection, we collect both types of materials. We have done this so that our collection will reflect the literary genius of the state as well as what others have thought or imagined about this place.

So, who is a Tar Heel? Is birth the determining factor? Is having grown up in the state or having lived in the state for a certain number of years sufficient? Is any item published while its author resides in the state a work of North Carolina literature?

This state has given birth to many writers who now live elsewhere: e.g., A.R. Ammons, Shirley Cochrane, Tony Earley, Michael Malone, Armistead Maupin, Jill McCorkle, Howard Owen, Tom Robbins, and Tom Wicker. Others, such as Alice Adams, Anne Tyler, Randall Kenan, and David Sedaris, were born elsewhere but raised in North Carolina. In some cases, the decision is easy - while Jill McCorkle has lived for some years in Massachusetts, her work clearly draws on her North Carolina experiences. Anne Tyler was born in Minnesota but grew up in Raleigh. She has lived in Baltimore for three decades and much of her work has been set in

\section{Each library must define for itself the term "North Carolina literature."}

the mid-Atlantic states. Yet her enormous popularity insures that virtually every public and college library in the state will buy her next novel. More difficult are the decisions about someone like Alice Adams or David Sedaris. Both were reared in North Carolina after being born elsewhere. Few, if any, of their works have North Carolina content, and neither has achieved as wide an audience as Anne Tyler.

Librarians also have to decide about people born elsewhere who moved into the state. Maya Angelou and Elizabeth Spencer are two writers who had wellestablished careers before settling in at Wake Forest University, and the University of North Carolina at Chapel Hill, respectively. Both continued to write and publish after they moved to the state. Collecting their new books seems to me appropriate, given the quality of their works (each has received the 
North Carolina Award for literature); but should a library attempt to acquire the works they published before moving to North Carolina?

Then there is the question of genre. Can the library collect in all genres, or should it limit itself to just one or two, such as poetry and mainstream fiction? The interests of patrons and the library budget are probably the chief considerations. For example, since most poetry appears in periodicals, meeting local interest will mean acquiring periodicals that regularly publish poetry. Is the library prepared to maintain subscriptions to a large number of literary magazines or to buy single issues containing pieces by one or more North Carolina authors?

Regardless of the genre, will the library collect all or just some editions (hardback, paperback, large print, translations, foreign imprints, etc.)? What about ephemeral materials such as chapbooks and poems published in programs and keepsakes? Nonprint formats such as audiobooks and adaptations for television or the movies also might be considered for addition to the collection. Is the library so committed to its North Carolina literature collection that it will buy manuscript materials or other pre-publication forms such as proof copies or advanced reading copies? ${ }^{6}$ Finally, what will the library save? Public and school libraries, and many college libraries, regularly weed their collections. Will the library's collection be one of current North Carolina literature, or will North Carolina literary materials be retained without regard to their age or circulation history so that the collection reveals the full literary heritage of the state? Each library must make its own decisions.

\section{Identifying Authors and Their Publications}

Identifying new North Caroliniana is one of the major parts of my job, and it is work that I relish. To track North Carolina writers and their work, I employ the standard print and online sources useful to any librarian building a collection of contemporary American literature. I regularly read Publishers Weekly. It includes news of specific forthcoming books, reprints, and adaptations. The reviews in each issue and the announcements in the seasonal preview issues are required reading, but other parts of the magazine can be helpful and interesting. Advertisements often include works that are not reviewed and usually include price and ISBN numbers. Through a business story in one issue, I learned that Warner Books had purchased the right to republish one of my favorite books of 1997, Susan Kelly's How Close We Come. ${ }^{7}$ By regularly scanning the business briefs, I followed the phenomenal sales of Charles Frazier's Cold Mountain and the growing popularity of Jan Karon's Mitford series. The news in Publishers Weekly also gives me a sense of which North Carolina writers are being energetically promoted by their publishers.

In addition to Publishers Weekly, I also regularly read Library Journal and the New York Times Book Review. Library Journal is useful because it reviews such a large number of books, and because its reviewers usually mention the setting of works of fiction. Through the reviews in the New York Times Book Review I occasionally uncover a writer's hitherto unknown connection to North Carolina; the Times's reviews also provide a national, professional perspective on the work of North Carolina authors. I also try to scan the book reviews in the magazines and journals to which I subscribe and those I acquire when I am traveling. Through book review magazines from other parts of the country such as the Hungry Mind Review from Minnesota, I sometimes discover a Tar Heel living and writing in some other part of the country. I also read as many publisher catalogs as I can. Of course, I look at the catalogs and publication lists of in-state presses, but I also look at the catalogs of such large commercial publishers as Random House and Simon \& Schuster, university presses, genre-identified publishers, and a number of small presses that often publish the works of North Carolina writers. Some of the publishers that have been surprisingly deep in North Caroliniana include the following: (for poetry) Copper Canyon Press, Gnomon Press, Louisiana State University Press, Nightshade Press, Papier-Mache Press, and (for science-fiction) Tom Doherty Associates.

Friends and colleagues often leave me suggestions for purchases, though seldom with a full bibliographic citation. Books in Print, now available both in print and online through OCLC's FirstSearch service, is invaluable for finding the complete ordering information. Publishers' Web sites are also good sources of information. Other online sources that I use regularly are the OCLC database and CARL Corporation's NoveList, both available through NC LIVE. I use these to check for other works by an author who has just come to my attention. OCLC also helps me sort out a title that has appeared in multiple forms or editions.

As good as these sources are, if I relied upon them exclusively, I would miss a large amount of what is being published by North Carolina authors. Attention to in-state sources of information is essential if you hope to develop an extensive collection of North Carolina creative writing. The local newspaper is a good place to start. A number of newspapers in the state, particularly the Charlotte Observer, the Herald-Sun (Durham), the Fayetteville ObserverTimes, the News \& Observer (Raleigh), and The Pilot (Southern Pines), have long supported the state's literary scene with good book pages that include book reviews, feature articles, author interviews, and calendar listings of upcoming readings. A town does not have to be large for the local paper to cover the local literary scene. Small town papers may not run many book reviews, but they frequently interview local authors and print a calendar of local literary events.

Statewide or regional cultural publications are also a source of information of books and writers. Some publications, like Brightleaf and the North Carolina Review of Books, focus on literature. In these you will get long reviews, essays, interviews, and advertisements that can alert you to new publications and new writers. For periodicals such as Creative Loafing, the Independent Weekly, and the Spectator, literature is but one of the subjects they cover, yet these publications include literary events in their community calendars and often contain book reviews, interviews, advertisements for books and bookstores, and essays on literary topics. The space given to literary matters in these publications is, to me, an indicator of the vitality of the state's literary community.

The book review pages in local papers often contain advertisements from local bookstores. North Carolina is blessed with a good number of local, independently owned bookstores, extending not quite from Manteo to Murphy, but from at least Manteo (with Manteo Booksellers) to Asheville (with Malaprop's Bookstore/Cafe and other book sellers). Despite the recent loss of Wellington's Books and The Intimate, the Triangle is still home to some of the finest bookstores in the country: the Regulator Bookshop and the Know Book Store and Cultural Center, both in Durham, McIntyre's Fine Books \& Bookends at Fearrington, and Quail Ridge 
Books, the Reader's Corner, and Books at Stonehenge in Raleigh. These local bookstores are in touch with the state's writers. Local stores tend to be most successful at tracking down local books that are hard to get through normal acquisitions channels. Although large, chain bookstores host readings by name authors on national book tours, it is at the local, independent bookstore that users are treated to a large number of readings by local authors. The newsletters, e-mail bulletin boards, and Web sites that many of the stores have are gold mines of information about books and writers. Getting on the mailing list at local bookstores is a good idea; an even better idea is to get to know the owner.

Many independent bookstores have sections or displays on local writers. Browsing these areas is one way to learn about the many publishers operating in the state. By my informal count, about 15 commercial entities in the state publish creative literature. ${ }^{8}$ Included in this number are established firms publishing both nonfiction and creative writing such as Algonquin Books, John F. Blair, and Down Home Press; presses associated with colleges in the state such as St. Andrews College Press, North Carolina Wesleyan College Press, and Mount Olive College Press; and a healthy number of small, independent presses including Banks Channel Books, Briarpatch Press, Carolina Wren Press, Horse and Buggy Press, Hummingbird Press, The Jargon Society, Lorien House, Persephone Press, Sandstone Publishing, and Scots Plaid Press. Few of these presses produce catalogs, but it is worth writing to each instate publishing firm and asking to be placed on its mailing list.

A good bit of literature, especially poetry, is found in periodicals rather than books. Subscriptions to statewide and local literary journals expose patrons to a wide range of authors, many of whom will never publish a booklength work. Librarians who scan these journals as part of their collection development routine will learn about new writers and see writers develop material that may later appear in book form. Deciding what in-state literary journals to subscribe to is not easy. The North Carolina Literary Review is a good selection for a statewide, multi-genre source, but it should be supplemented with journals from your town or region, if such exist. Librarians should not overlook the literary journals published at many of the colleges around the state - it's likely that the famous Tar Heel authors of the twenty-first century are publishing in their college literary magazines today.

In addition to subscribing to a range of literary magazines, librarians may want to write some of the literary associations in the state and ask to receive their newsletters and to be placed on their mailing lists. The newsletter of the North Carolina Writers' Network is a great source for information on writers, as are publications of other, more specialized, groups such as the Carolina African American Writers Collective, the Carolina Romance Writers, North Carolina Haiku Society, the North Carolina Poetry Society, and the Writers Group of the Triad. Carefully watching the community calendar in the local newspaper or entertainment tabloid enables librarians to learn about local groups, when they meet, and the name and phone number of a contact person.

Another way to build knowledge and make contacts is by attending individual author readings and book signings, and by participating in the many literary festivals around the state. Recurring events include the North Carolina Writers Conference, the North Carolina Writers' Network Fall Conference, the North Carolina Poetry Society conventions, the Asheville Poetry Festival, the Spring Literary Festival in Charlotte, the Festival for the Eno, and an annual book festival in Cary. These are complemented by one-time or irregularly scheduled events such as readings at restaurants, art galleries, and community centers such as the Hayti Heritage Center in Durham. ${ }^{9}$ Finally, librarians should not overlook the people they know as they build their knowledge of North Carolina authors and their library's collection of creative writing. I find that my friends and colleagues have interests that are not the same as mine, that they read different things than I do, and that they turn up information on books and authors that I would not find on my own.

It is pleasant to devote personal and professional time to following North Carolina literature. Unfortunately, I have other claims on my time, and so does every other librarian in the state. Each year, as a way to judge how well I am doing in collecting the work of the state's writers, I check my order and received files against the list of nominees for the Sir Walter Raleigh Award for fiction, the Roanoke-Chowan Award for poetry, and the Association of American University Women Award for juvenile literature. Despite my best efforts, every year at least twenty percent of the nominated books are unknown to me. This gives me pause. I tell myself that this is a measure of the vitality and diversity of North Carolina's literary scene rather than a measure of my inadequacy, and then I immediately order those overlooked titles. So many books, so little time ....

\section{References}

1 Sally Buckner, "Fertile Soil," Spectator, 1030 (November 4, 1998): 11-12.

2 Curt Johnson, ed. Who's Who in Writers, Editors \& Poets: United States \& Canada. 1995-1996 ed. Highland Park, IL: December Press, 1996.

3 The first of these bibliographies, covering the years 1931-1933, and composed by Mary Lindsay Thornton, appeared in the April 1934 issue of the North Carolina Historical Review (NCHR). Later bibliographies, compiled by the curators of the North Carolina Collection, appeared annually thereafter. Robert G. Anthony, Jr. compiled the most recent bibliography which is forthcoming in April 1999 NCHR issue.

4 These are the AAUW Award for juvenile literature; the Mayflower Award for nonfiction; the Roanoke-Chowan Award for poetry, and the Sir Walter Raleigh Award for fiction. A complete listing of the winners of each award appears elsewhere in this issue.

5 Carolina Comments. Raleigh: North Carolina Division of Archives and History. Bi-monthly.

6 These are surprisingly easy to acquire from used bookstores in metropolitan areas of the state or from out-of-print dealers who specialize in literature.

7 This novel was the winner of the first Carolina Novel Award, established in 1996 to recognize excellence in fiction writing by Carolina authors. The novel was first published by Banks Channel Books of Wilmington, the contest's sponsor. Its word-of-mouth sales and reviews were so good that Warner Books contracted to re-issue the work in hard cover. The winning book for 1998-1999 is Judith Stacy's Styles by Maggie Sweet, from Banks Channel Books.

8 The 1997 edition of North Carolina Literary Resource Guide (Carrboro, N.C.; The North Carolina Writers' Network) lists twenty-one small presses. A definitive number is hard to come by since many small publishing firms are short-lived, and it is not always easy to tell when a "publishing firm" is really just one person publishing his own works and those of his friends.

9 "Spotlight on Culture," News \& Observer, January 20, 1999. 


\title{
A Noble Tradition: Creative Writing at UNCG
}

\author{
by William K. Finley
}

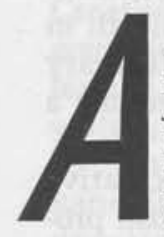

llen Tate, Peter Taylor, Randall Jarrell, John Crowe Ransom, Robert Lowell, Richard Wilbur, Katherine Anne Porter, Carolyn Gordon, Robert Penn Warren, Elizabeth Bowen, Richard Eberhardt, W. D. Snodgrass, Reynolds Price, Fred Chappell, Donald Hall, Kay Boyle, R. V. Cassill, Andrew Lytle, Robert Frost, Eudora Welty, William Styron - the names read like a Who's Who of twentieth-century American literature. This distinguished group has one thing in common: since the late 1930 s they have participated at various times and to varying degrees in the esteemed Creative Writing Program at the University of North Carolina at Greensboro. With this glittering array of talent as support, the university's Creative Writing Program has long been rated one of the best in the country.

Although the Creative Writing Program was not organized fully until 1965 , the teaching of creative writing at the university goes back much further. Under various designations, classes in rhetoric and composition have been taught at the North Carolina State Normal and Industrial School (as the university was first called) since its opening in 1892. The English curriculum in the very first Annual Catalogue includes an untitled "Course IV" which enforced "practice in writing." "Writing," however, did not necessarily mean creative writing, a course of instruction generally foreign to American universities of that time. The English Department's stated purpose for its writing classes was to assure "the acquisition of the ability to use the lan- guage with simplicity and force by means of composition in its simpler forms, e.g., letters, reproduction exercises and essays." Institutional interest in encouraging creative writing would not come until later.

By 1918 , however, two-semester courses were offered in both short-story writing and versification ("a course designed for that limited number who wish help in the simpler forms of verse making"). In 1920, "The Writing and Editing of News" replaced "Versification" in the English curriculum, while "The Short Story" was reduced to a single semester. In 1923 "Play Writing" joined "The Writing of News," but courses in writing short stories and poems were curtailed (although "Poetics" included "practice in writing simple pieces of verse"). Obviously, for most students, creative writing as an academic discipline was not compelling. For the 1924-1925 academic year, "English Composition" included "practice in the short story," while the courses in news writing and playwriting continued. In this year was added "The Writing of Verse," "limited to fifteen students who have a real desire to express themselves in verse." The reinstitution of such courses reflected a national trend among American colleges to develop classes in creative writing.

In 1927 a course simply called "Creative Writing" first appeared, with a focus on "practice in the short story, the essay, and other literary forms." This was the first course at what was now called North Carolina Woman's College to encompass training in more than one lit- erary genre. This hybrid course joined the existing course in "Play Writing" and "The Writing of Verse" to form the creative writing component of the English curriculum. All courses in creative writing were electives; none were required to major in English.

In January 1938 the first of many illustrious writers joined the English faculty at the Woman's College of the University of North Carolina. Allen Tate came from Vanderbilt as full professor to teach the art of poetry writing. He had already written six well-received books of poetry, a volume of literary essays, and two biographies and was completing his first novel. Coming to Woman's College at what he called a "fabulous salary," Tate brought with him his wife, the novelist Caroline Gordon, herself the author of four books. He did not inherit the general "Creative Writing" courses, but he taught both "The Writing of Verse" and "The Writing of Literary Criticism," while Gordon taught a new course, "The Writing of Fiction." With the arrival of these two distinguished authors, it may be said that creative writing became established as a fully-recognized component of English studies at the Woman's College, although there was as yet no opportunity for a concentration in writing.

For 1939-1940 Tate added a course in "Special Projects in the Writing of Criticism and Verse," a class designed "for students desiring to master a critical style or to study intensively the techniques of verse." Gordon taught a complementary "Special Projects in the Writing of Fiction." "The Writing of 
News" continued to be taught, as did the general "Creative Writing" classes. After the 1939-1940 academic year, Tate and Gordon left Woman's College for Princeton, where Tate had been named Poet in Residence; and the advanced specialized writing classes in poetry and fiction temporarily ended.

In 1940-1941 "Play Writing" resumed, and in 1943 the Creative Writing courses were renamed "Writing Workshops," covering the writing of fiction, drama, and poetry. The first to teach these classes under the new designation was Hiram Haydn, fresh from a Ph.D. program at Columbia and some years away from achieving his reputation as a foremost editor and author. He remained at Woman's College only two years, leaving to become editor of American Scholar. Today, these broad classes still are carried in the English curriculum under the same title and course number.

In 1944 there first appeared at the Woman's College what was to be an important supplement to the creative writing program. The Arts Forum, initiated by English professors Marc Friedlaender and Winfield Rogers, invited to campus distinguished representatives from many fields of arts and humanities, including well-known authors to read and lecture and to discuss and analyze student writing. Over the years such esteemed writers as Robert Lowell, Robert Penn Warren, Katherine Anne Porter, John Crowe Ransom, Robert Frost, Saul Bellow, Elizabeth Bowen, and Seamus Heaney visited Woman's College to give both readings and advice to student writers. These visitations, though generally brief, not only enhanced the instruction given to students in creative writing, but brought recognition and prestige to the college. Today, visits from renowned writers continue to enrich the educational experience in creative writing at UNCG.

In the Fall of 1946 a second major talent joined the English Department at Woman's College to teach creative writing. Although he did not bring with him the distinguished publication record of Allen Tate, Peter Taylor had already published fiction in national magazines and showed great promise as an author. Drawn to the world of teaching after spending four years in the military in World War II and a brief stint as a reader with the publishing firm of

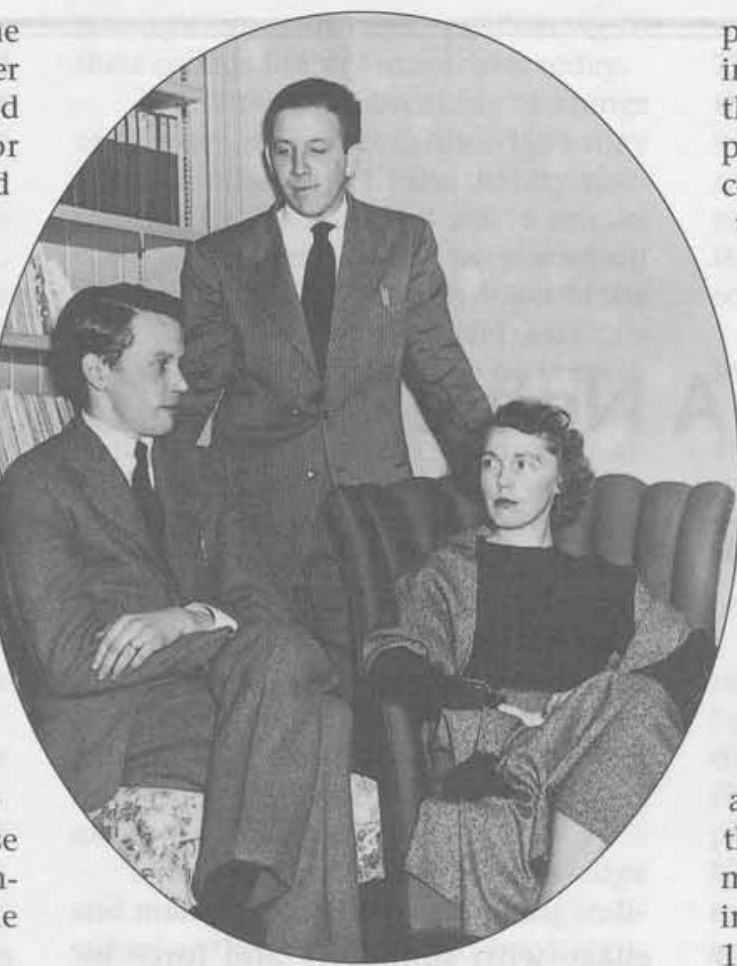

Richard Wilbur, Peter Taylor, Jean Stafford at 1949 Arts Forum, UNCG.

Henry Holt, Taylor had studied poetry under Tate at Southwestern University and under John Crowe Ransom at both Vanderbilt and Kenyon College, where he roomed with the poet Robert Lowell. But Taylor's strength was fiction, not poetry. At Woman's College he revived the specialized fiction-writing courses that years before had been taught by Caroline Gordon. In time, Taylor would win a Pulitzer Prize and many other distinguished awards for his fiction and would become one of the most respected names in American literature.

The following year Taylor was joined by Randall Jarrell, a classmate and close friend from Vanderbilt. Likewise a World War II veteran, Jarrell had been a literary editor at The Nation and had published two volumes of poetry. Jarrell would go on to win the National Book Award for poetry and fiction and achieve great acclaim as one of America's finest

poets. Taylor and Jarrell shared the Writing Workshop courses, Taylor teaching the fiction component and Jarrell the poetry. Unlike many authors who accepted teaching positions merely to pay the bills while they concentrated on their writing, Taylor and Jarrell shared

a genuine love of teaching and discussing the art of good writing. Their interest in students and their enthusiasm for teaching ushered in a golden age of creative writing instruction at Woman's College.

When Taylor took a leave of absence in 1948-1949, his place in the Writing Workshop was taken by Lettie Rogers, a graduate of Woman's College and a former member of the Sociology Department who had published her first novel to much acclaim in 1946. Rogers would write three more novels and be a teacher and mentor to several future writers, including Doris Betts. Her untimely death in 1957 at age 39 deprived the literary world of what might have become a major talent.

In 1949 the merit of the creative writing component of the English program was recognized by its prominent inclusion in the newly formed Creative Arts Program at the Woman's College (strongly endorsed and aided by Woman's College Chancellor, Walter Clinton Jackson) and a new graduate degree, the Master of Fine Arts, with majors in painting and graphic arts, dance, music composition, or writing. New courses in advanced fiction, poetry, and playwriting ("reserved for those writers who have been encouraged to continue creative work") and graduate seminars in writing were established; and a required thesis for the MFA degree in Writing called for original work in the genres of novel, short stories, poetry, or drama.

Joining the English Department in 1950 was Robie Macauley, a young writer of short stories who showed much promise. The English Department now boasted four distinguished writers in its creative writing program: Taylor, Jarrell, Rogers, and Macauley. Jarrell taught the

[Peter Taylor's and Randall Jarrell's] interest in students and their enthusiasm for teaching ushered in a golden age of creative writing instruction at Woman's College. poetry sections, Taylor and Rogers handled fiction, and the versatile Macauley taught both poetry and fiction. By this time the writing program within the English program had been greatly expanded. In addition to courses in poetry, fiction, playwriting, and journalism, 
the department since 1947 offered a course in "Writing for Radio" and extended this course in 1950 to "Writing for Radio and Television," undoubtedly one of the earliest courses in the country to respond to the new popularity of television.

By 1954 Randall Jarrell was all alone in the Writing Workshop. Peter Taylor and Robie Macauley had both left for other positions, and Lettie Rogers taught only classes in Advanced Composition. For the next ten years Jarrell essentially was the creative writing program at Woman's College, helped out only by the occasional visiting professor. One of the most admired and beloved instructors on campus, he remained the dominant figure in the creative writing program for 18 years. His death in October 1965 left a tremendous void in the Creative Writing Program. Eulogized by colleagues, distinguished writers, and especially by his students, Randall Jarrell left an unmatched legacy of brilliant talent, teaching ability, and genuine concern for students, a legacy reflected in UNCG's Randall Jarrell Fellowship in Writing.

Fortunately, the English faculty had competent replacements. Peter Taylor rejoined the program from 1963 to 1967 for his third and final stint. In 1964 Fred Chappell joined the English faculty from

Duke; and Robert Watson, who had been a member of the department since 1953, teaching mainly literature classes, moved into the creative writing component. Currently North Carolina's Poet Laureate, Chappell would eventually publish more than 20 volumes of poetry and fiction and win many prestigious awards, among them the coveted Bollingen Prize for Poetry and the T. S. Eliot Award. Watson's poetry also would receive many awards, including a Pulitzer Prize nomination in 1966 for his second volume of poems. The postJarrell era in creative writing at Woman's College began with reassurance that the quality that Jarrell reflected would continue. Occasionally, visiting professors of the stature of Allen Tate, Gibbons Ruark, and Alan Shapiro would enhance the program with their presence. Today the Creative Writing Program is in the capable hands of Chappell, Lee Zacharias, H. T. Kirby-Smith, Michael Parker, Stuart Dischell, and Jim Clark, who serves as director.

These prominent writers and teachers represent one-half of the success story of UNCG's Creative Writing Program; talented and dedicated students constitute the other half. Since the university's beginning in 1892, there has been strong interest in writing among students. In the very first year, two student literary societies were formed: the Adelphian and the Cornelian. A third

tained only a few short poems or stories to reflect the creative urge.

Beginning with the October 1910 issue, however, a new impulse characterized the magazine. Now more than twice the length of previous issues, this issue contained five stories and five poems from students, as well as essays and short commentaries on a variety of subjects. This new focus set the tone for subsequent issues. Thus a prestigious new creative voice was born on campus. By the time The State Normal Magazine changed its name to Corradi (an amalgam of "Cornelian," "Adelphian," and "Dikean") in 1919 , the content was almost entirely poetry or fiction. Beginning in 1946, a special Arts Forum issue of Corradi welcomed student writing from other universities. Works chosen for this special issue were discussed and analyzed by the Writers Committee during the annual Arts Forum conference. The quality of this publication is indicated by the number of contributors who later achieved literary prominence. Among those who contributed over the years were Flannery O'Connor, James Dickey, Guy Davenport, Donald Hall, Wendell Berry, Borden Deal, Anthony Hecht, Heather Ross Miller, and Sylvia Wilkinson.

Students enrolled in both the undergraduate and graduate creative writing programs have published their works in leading magazines and have won numerous lit-

society - the Dikean - appeared in 1918 and a fourth - Aletheian - in 1922. Active and prestigious, these literary groups encouraged creative expression and provided an outlet for student literary endeavors. The first literary magazine at the university dates from March 1897. Called initially The State Normal Magazine, the quarterly publication was edited by members of the Adelphian and Cornelian societies and consisted almost entirely of student work. The early issues focused more on campus news and scholarly critiques than on fiction or poetry, and generally con-

Few programs in the nation
can boast a history that
includes so many awards
won by faculty and students.


at UNCG are Margaret L. Coit, Eleanor Ross Taylor, Robert Morgan, William Pitt Root, Heather Ross Miller, Kelly Cherry, Tim Sandlin, Sylvia Wilkinson, and Doris Betts.

In 1965 the MFA Creative Writing Program at UNCG was formalized and accelerated. A new emphasis distinguished this program from other MFA offerings at the university, and the staff sought the most accomplished student writers from across the nation. At this time only two official creative writing programs existed in the country - at Stanford and the University of Iowa. Students were now accepted as a "class" into the two-year graduate program and became a tightlyknit group who discussed writing and analyzed one another's work in formal classes or informal gatherings on or off campus.

The next year saw the founding of an important new campus publication. While Corradi remained the chief outlet for undergraduate writing, the newly focused MFA Creative Writing Program needed a different publication for graduate work. The Greensboro Review was founded by faculty member Robert Watson and several graduate students as a vehicle for graduate writing. Watson, Peter Taylor, and Fred Chappell sat on the first editorial board. Originally intended solely for UNCG students in the Creative Writing Program, the magazine soon expanded to include, first, graduate students from other universities, and then writers in general - students, faculty, or freelancers. Among the prominent contributors since the magazine's beginning have been Joyce Carol Oates, Robert Bly, May Swenson, Walter Lowenfels, William Peden, Guy Owen, Dabney Stuart, James Applewhite, and Sallie Bingham. The best indication of The Greensboro Review's quality came when the Winter 1987-1988 issue had four stories selected for inclusion in distinguished short story anthologies. Still going strong, The Greensboro Review recognizes and encourages good writing, especially by newcomers, by presenting annual awards for best submissions of previously unpublished fiction and poetry. Over the years, publications in the magazine have won numerous prestigious awards.

Since the first creative writing courses were offered at the State Normal and Industrial School over 80 years ago, the writing component at UNCG has grown to great renown. Few programs in the nation can boast a history that includes so many awards won by faculty and students. The quality of the program was proclaimed in 1994 when George Garrett, Hoyns Professor of Creative Writing at the University of Virginia, in an article for the Dictionary of Literary Biography Yearbook 1994 titled "Who Runs American Literature?" ranked

tion is unique. Writers whose manuscripts are represented in Jackson Library include Margaret Coit, Jean Farley, Edythe Latham, Robie Macauley, Heather Ross Miller, Michael Parker, Lettie Rogers, Jessie Rosenberg Schell, Joan Cox Spears, Eleanor Ross Taylor, Peter Taylor, Robert Watson, Sylvia Wilkinson, and Emily Herring Wilson. Related collections include The Greensboro Review, the Black Mountain Poets, and the papers of Olive Dargan and Lois Lenski.

While the Peter Taylor Collection contains much useful research material on a major literary figure, the most significant research collection in the Creative Writing Collection is undoubtedly the Randall Jarrell Collection. Not only does this important collection contain manuscript and typescript copies of many of Jarrell's poems and essays, but it also includes class and lecture notes, photographs, memoranda, news clippings, annotated books, and other material which help document both Jarrell's career and the development of the Creative Writing Program at UNCG. The collection is one of the most heavily used in Special Collections and has proved in-

UNCG's MFA Creative Writing Program fourth in the nation, ahead of such wellknown programs as those at the University of Iowa and Johns Hopkins.

The development of the Creative Writing Program at UNCG is documented by the breadth of research materials in the Special Collections \& University Archives Department of Jackson Library. In 1997 a new focus and emphasis were created in gathering a number of separate collections of creative writing under a general heading to form the Creative Writing Collection.

Among the relevant books are publications of staff and students in the Creative Writing Program. Shelved in the university archives are complete runs of both Corradi and The Greensboro Review. Copies of all university catalogues and bulletins from 1892 help document the evolution of creative writing courses. Special files devoted to Creative Writing, the Arts Forum, The Greensboro Review, and many individual faculty and students add valuable information on the history of the program.

It is in the area of manuscripts, however, that the Creative Writing Collec- valuable to scholars preparing books and articles on Jarrell's life and works.

Woman's College Chancellor Walter Clinton Jackson's hope in the 1940 s that the MFA program in Creative Writing would become one of the best in the country has been realized. Tate, Taylor, Jarrell, Watson, and other luminaries in the program are gone, but a distinguished staff and high-caliber students remain to lead UNCG's Creative Writing Program into the next century.

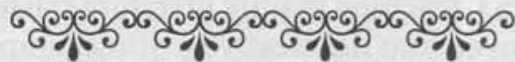 Thank You to NCLA Contributing Members:}

David S. Ferriero, Duke University

Dr. Benjamin F. Speller, Jr., North Carolina Central University SOLINET

Tom Broadfoot,

Broadfoot's Publishing Company 


\title{
Writers and Libraries: A Symbiotic Partnership
}

\author{
by Jinnie $Y$. Davis
}

$T$ he American library has long held a special place in the hearts and minds of writers who remember its enduring effect on their lives. As the writer Anne Rockwell eloquently expressed it, she learned as a child that the library is "a powerful place. I soon discovered it was miraculously alive with the thoughts of people I would only know through their books... Through reading I learned to journey out of myself and back again, but on the return voyage I brought riches and power in the form of thoughts to last a lifetime. It was impossible to be lonely there. ${ }^{11}$ Even beyond offering the wealth of its collections, however, the library as an organization is able to form special ties with writers, which can work to their mutual benefit. Many public libraries, especially those in large cities, have wonderful and wellestablished writer programs. Academic libraries, on the other hand, have not fully exploited this opportunity. This paper chronicles two examples of writer-library collaborations at the North Carolina State University (NCSU) Libraries.

The Friends of the Library (FOL) of North Carolina State University has an array of programs featuring authors. For example, the Spring Dinner is the FOL's primary public relations event and has been in existence since 1969. Each year, writers of national repute are invited to speak or to read from their works. Past speakers included Doris Betts, William Leuchtenburg, and John Ehle. The Fall Luncheon, inaugurated in 1981, high- lights authors among NCSU's own faculty. It offers the audience a glimpse into the fertile intellectual life of the campus community, with talks on such diverse topics as the Latin American gaucho, the excavation of the 2,000year-old Roman port of Aila, or the Indonesian tiwah burial ritual. In addition, the FOL sponsors several special lectures and readings by authors over the course of the academic year. During the NCSU Libraries' centennial in 1988/ 89 , the library administration created two new programs that sought to focus specifically on writers in this state: the Author of the Year and the North Carolina Writers Series.

Now in its eleventh year and renamed the Author-in-Residence, the Author of the Year is probably the oldest program in this country that ensconces a writer in a formal relationship with an academic library. The most innovative aspect of this arrangement was the formation of a rich symbiosis between a writer and the library. Its origins were serendipitous: Susan K. Nutter, the new director of the NCSU Libraries in 1987, had long been aware of the state's literary fame. As native North Carolinian Manly Wade Wellman had written years ago:

Every state has its pretensions [to a literary reputation] ... But North Carolina has made its claims valid. Elsewhere in the country, one meets with a sense that North Carolina is a natural breeder of creative writers ... I, myself, have known aspiring young students of creative writing, who have seriously and honestly felt that, if only they could come to North Carolina, their careers would blossom and become fact. Oddly enough, that has happened, with more than one such [individual]. The designation of "North Carolina Writer" has become a coveted one, and a flattering one, within recent years. ${ }^{2}$

Nutter considered the library a perfect organization for nurturing writers, especially young authors who had some affiliation with the university, and hoped to rejuvenate the FOL with a new 


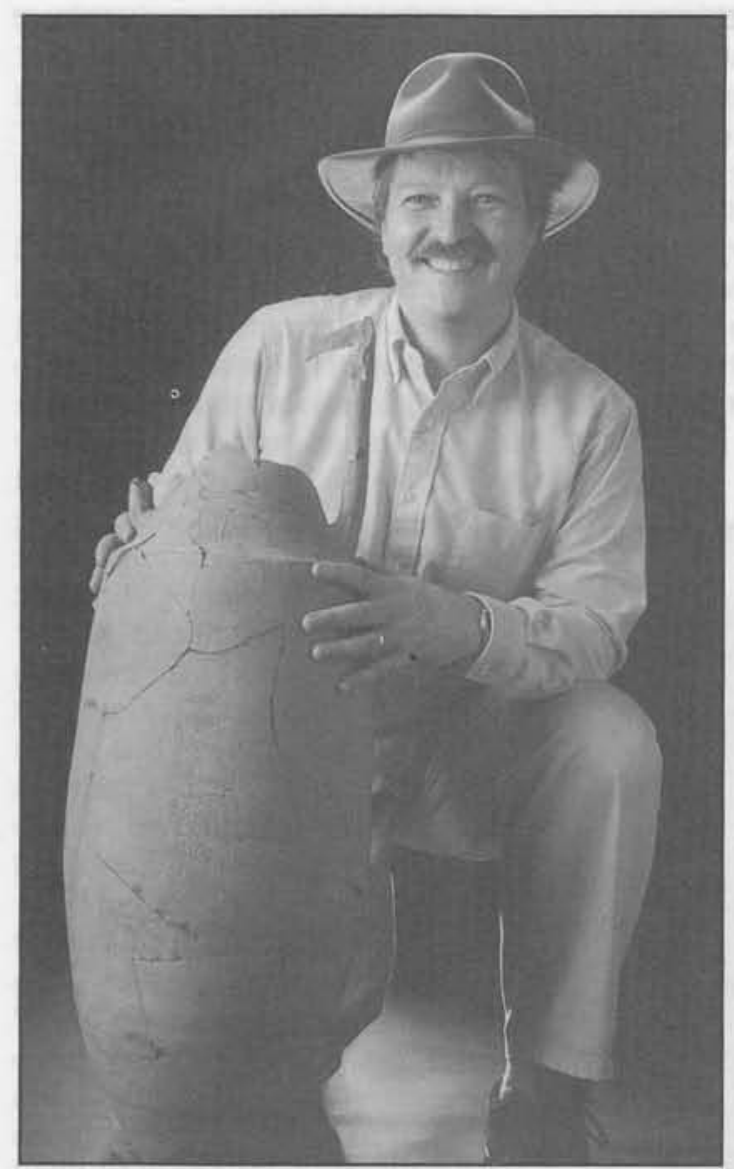

filiation, in finding a quiet place away from home to concentrate on her writing. Nutter knew that she had found the ideal match for a unique public relations and development program under the sponsorship of the Friends of the Library, the Author of the Year.

From the start, the Author of the Year program was designed to establish the reputation of the NCSU Libraries as an environment highly supportive of writers. Recognizing that writing is essentially an activity conducted in solitude and that young authors often must struggle to make a living solely through their writing, the library wanted to foster the careers of promising young, local writers. As a research library in a land-grant institution renowned primarily for its science and engineering programs, but building a reputation in the humanities and social sciences as well, the NCSU Libraries hoped to strengthen its role as a literary center in the state. This ambition was actually a natural

Professor S. Thomas Parker describes his excavations at the Roman city of Aila at the 1995 Fall Luncheon.

program based on the writer-library bond. She asked the library staff for ideas about potential candidates and was pleased to hear from Ron Simpson, head of the library's Technical Information Center. Simpson mentioned that Kaye Gibbons, a former student assistant of his, had just published her first novel at the age of 25 . Ellen Foster was garnering critical acclaim, both nationally and internationally. Nutter was intrigued and attempted unsuccessfully to reach Gibbons. She was surprised one day to find that Kaye Gibbons had come to her. Having heard that the library director was looking for her, the author decided to find out what Nutter wanted, and the two spent the rest of the afternoon in conversation. Gibbons talked about her student days, when she had spent so much time haunting the D. H. Hill bookstacks that she called herself "the phantom of the library." She also mentioned her current difficulties, in the absence of an institutional af-

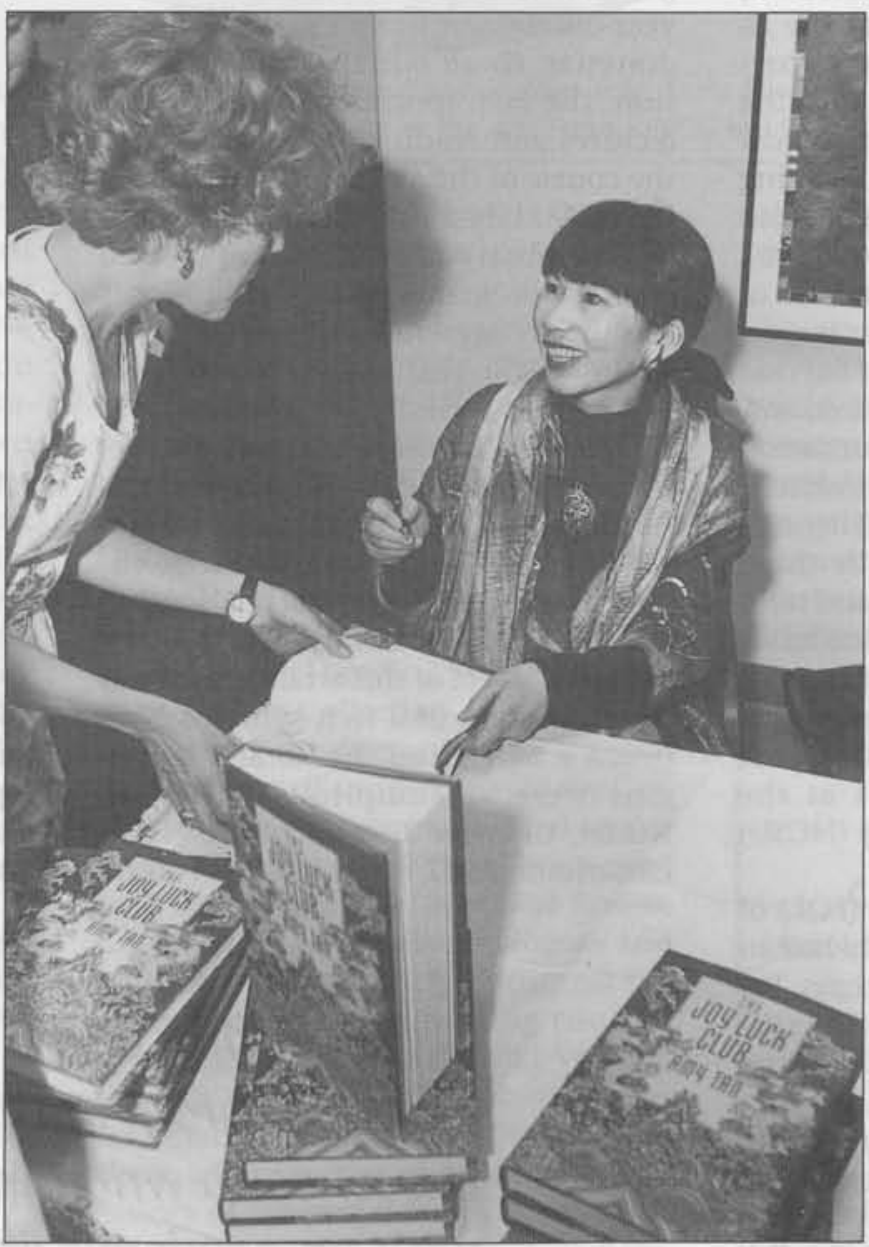

Amy Tan autographs books at the 1990 Spring Dinner. one for a university with a well-respected creative writing program and an active humanities extension program. The Author of the Year was seen as a concept that could enhance the NCSU Libraries' public relations and fundraising programs, thereby highlighting its extension and public services role within the university. Moreover, by acquiring copies of the author's books, the libraries could expand its collection of autographed first editions. The library also hoped that the Author of the Year program would provide the FOL with a regular source of speakers for its events. Finally, the opportunity for library employees to work closely with authors would help the staff better understand the creative writing process, out of which emerges the collections that are at the core of any library.

The author would receive tangible benefits in turn. A one-year faculty appointment as visiting lecturer (without salary but with faculty privileges) would give the appointee both an institutional base and a place to work. The NCSU Libraries designated an individual, locked study room in the main library for the exclusive use of the Author of the Year.

The library also offered unlimited access to its collections' resources, free database searching, use of the staff lounge, and library borrowing privileges at NCSU, Duke, and UNC-Chapel Hill. Both library and FOL functions provided the author with many publicspeaking opportunities, as well as publicity and sales opportunities throughout the year. In addition, the Friends of the Library bestowed honorary life membership on the Author of the Year.

Nutter secured the backing of the FOL Board of Directors and university administration to inaugurate the program, and Kaye Gibbons was installed in 1988 as the Friends of the Library's first Author of the Year. Early on, the NCSU Libraries set several measures whereby the success of the program might be gauged. They included primary and secondary measures:

- completion of arrangements for physical facilities, 
equipment, and services for the Author of the Year

- attendance by the Author of the Year at Friends events

- increased attendance at North Carolina Writers Series lectures and other FOL events

- increased publicity about the NCSU Libraries and its Author of the Year Program

- increased involvement of the NCSU local and regional communities with the Author of the Year Program

- improved library programming sponsored by the FOL

- closer personal ties between the Author of the Year and the NCSU Libraries' staff

- increased Friends membership

- increased contributions to the Friends

The program got off to a splendid start and, by all measures, was deemed a success. The NCSU Libraries and the Friends did their part in creating a supportive community for Gibbons, with both the environment and resources that would help to promote concentrated work. The room selected as the Author of the Year's study held special significance because its previous occupant had been the late NCSU professor Richard G. Walser, a long-time champion of North Carolina literature. As a student, Gibbons had enjoyed seeking out Walser's company to talk with him about Thomas Wolfe. The FOL also purchased a computer workstation and printer for Gibbons's use.

In return, Gibbons agreed to participate without honoraria in several library events. In the first year alone, she spoke at the FOL's North Carolina Writers Series and delivered another lecture open only to members of the NCSU Libraries staff. At lectures by other speakers, Gibbons introduced her fellow writers. She participated in a library-sponsored Faculty Book Fair and held autographing sessions for her fans at various library events such as the Spring Dinner and a reception for graduating seniors. In sum, she contributed her talents as a speaker, her popularity as an author, and her literary contacts to enhance the library's public relations efforts, and the Libraries gained a wellknown, effective advocate for its broader goals. Beyond the formal aspects of the Author of the Year program, both partners were enriched by closer personal ties. In her 1991 novel A Cure for Dreams, Gibbons acknowledged the support of Susan Nutter and the Friends of the Library.

News of the Author of the Year program received national attention when Library Journal featured a cover photograph of Kaye Gibbons in the bookstacks of the D. H. Hill Library. The journal hailed the NCSU Libraries' Author of the Year program as "perhaps the most exciting example of author involvement with libraries." 3 The "Author of the Year" title was soon replaced by "Author-in-Residence" as both the NCSU Libraries and Kaye Gibbons grew comfortable in their mutually support- ive roles.

Ten years later, Kaye Gibbons is still the FOL's Author-in-Residence. Now the author of six novels and numerous essays, she is in demand as a speaker who is entertaining, moving, and profound. In December 1997, Gibbons catapulted to national celebrity status when television talk show host Oprah Winfrey announced her selection of two of Gibbons's works, Ellen Foster and A Virtuous Woman, for her influential book club. At the same time, a television production of Ellen Foster appeared on the Hallmark Hall of Fame. Gibbons's fame,

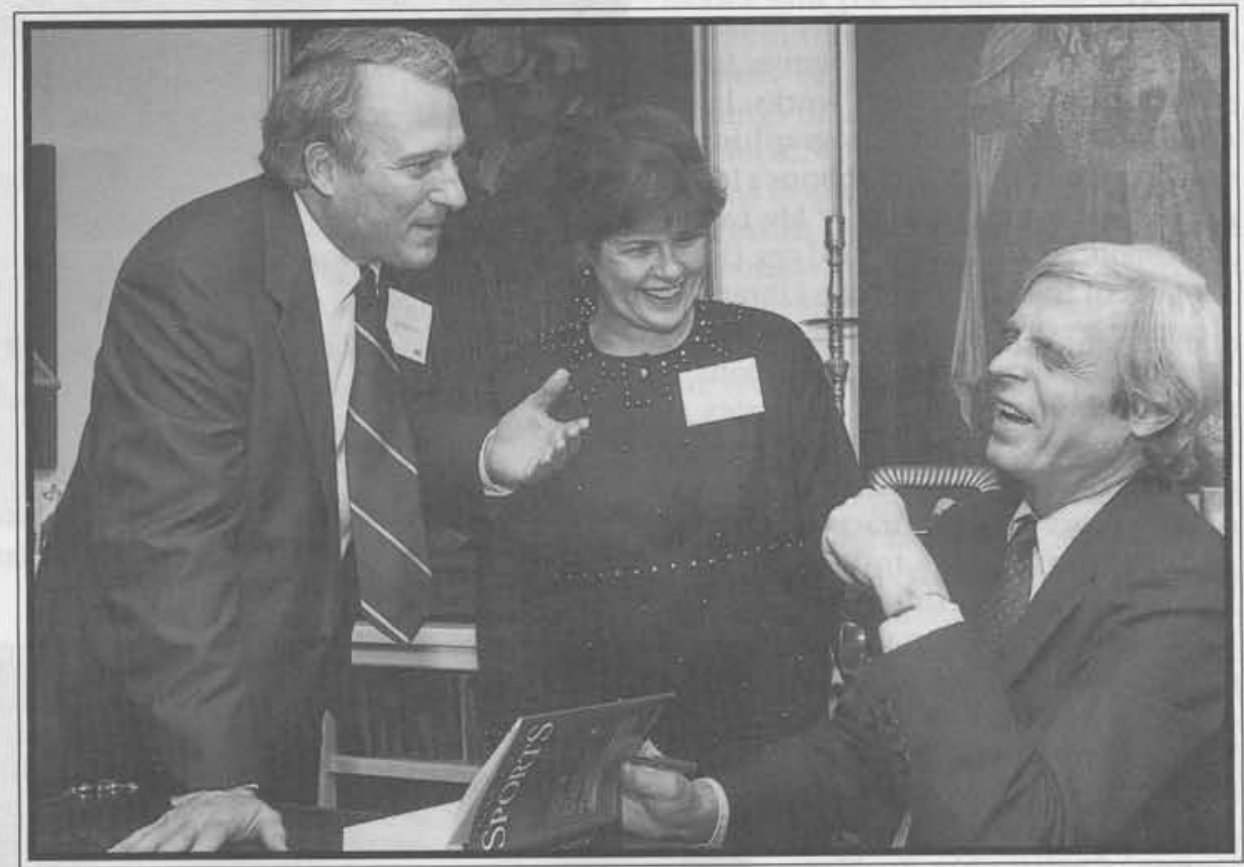

George Plimpton (right), 1993 Spring Dinner speaker, enjoys a laugh with NCSU coach Les Robinson and his wife.

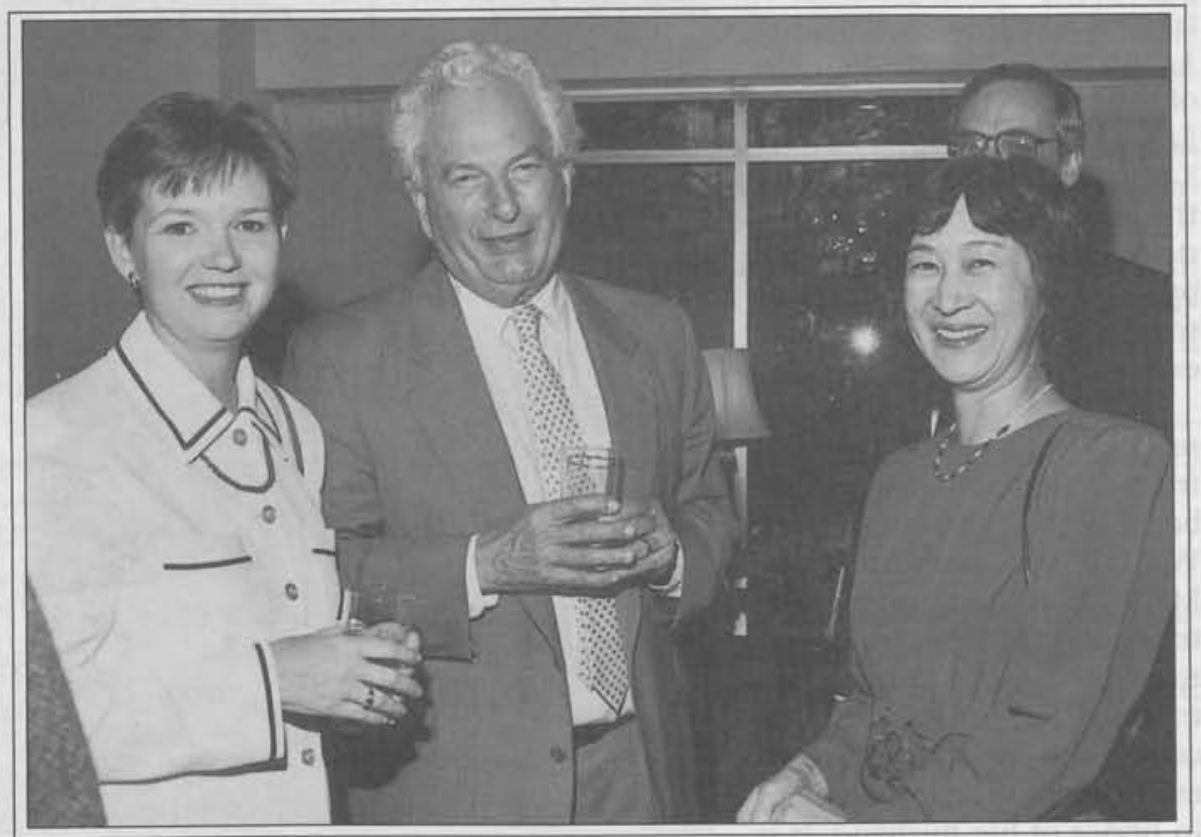

Author-in-Residence Kaye Gibbons (left) and Jinnie Y. Davis (right) with the 1995 Spring Dinner speaker, Joseph Heller. 
however, rests upon solid literary credentials. The literary merit of her works has been recognized in a steady stream of honors. They range from individual prizes, such as the Sue Kaufman Prize for First Fiction from the American Academy and Institute of Arts and Letters, to awards for her corpus of works, such as the Chevalier de l'ordre des arts et des lettres (Knight of the Order of Arts and Letters) from the government of France, an honorary doctorate from North Carolina State University, and the prestigious North Carolina Award in Literature.

Kaye Gibbons's ties to the NCSU Libraries remain vigorous. The library continues to offer regular venues for the Author-in-Residence's works, including readings and autographing sessions. The preface to Gibbons's latest book, On the Occasion of My Last Afternoon, again acknowledges the support of the Friends of the Library. Now an ex-officio member of the Friends' Board of Directors, Gibbons still actively supports the Libraries. For example, she used the literary contacts developed over several years of book tours to help attract writers of national prominence to Raleigh. In her first year as resident author, Gibbons personally recruited best-selling novelist Amy Tan to speak at the FOL Spring Dinner, and has since helped bring in authors such as George Plimpton, Dominick Dunne, Christopher Buckley, Joseph Heller, and John Grisham. Grisham, who attracted a sellout audience of 1,000 , made special mention of the fact that he had come to Raleigh "quite simply, because Kaye Gibbons asked me." Like the other authors, he also participated in a fundraiser hosted by Gibbons in her own home to help raise money for library endowments.

The Libraries also has reaped unexpected benefits from its association with Gibbons. With her husband Frank Ward, Jr., she established The Mary Alice Ward Endowment to support the Libraries' collections, and she is a regular contributor to the Friends. Recently, she announced the establishment of an endowment in honor of her husband. It is also noteworthy that Gibbons has chosen to donate her pa- pers to the NCSU Libraries' Special Collections Department. These records document the author's editing and writing process and will prove an invaluable resource for future literary researchers.

Among the secondary measures of success were indicators of the overall growth of the Friends of the Library as an organization that exists to support the Libraries. The achievement of these goals also reflected the success of the Author-in-Residence, N.C. Writers Se-

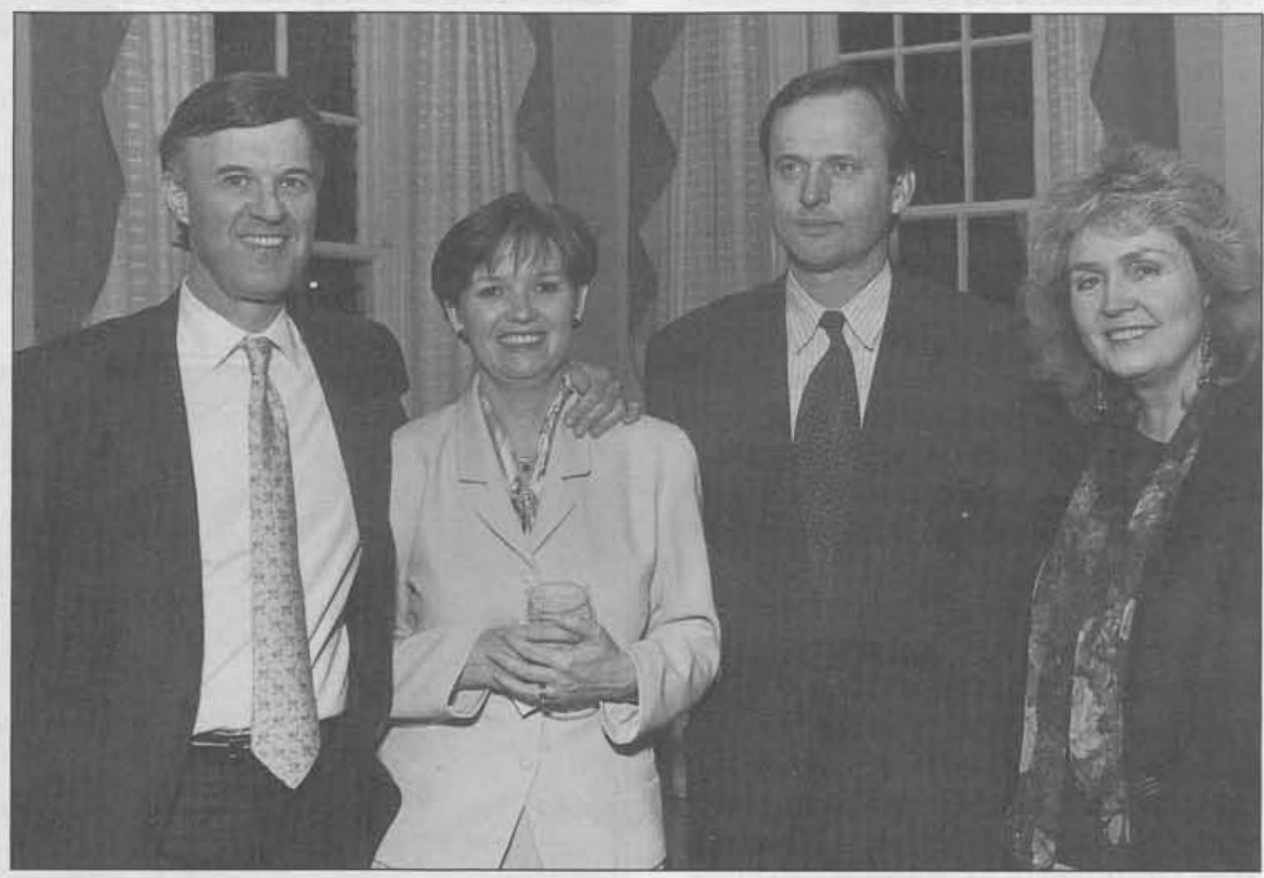

(Left to right) Frank Ward, Jr., and Kaye Gibbons at the 1996 after-dinner fundraiser with John Grisham and Lee Smith.

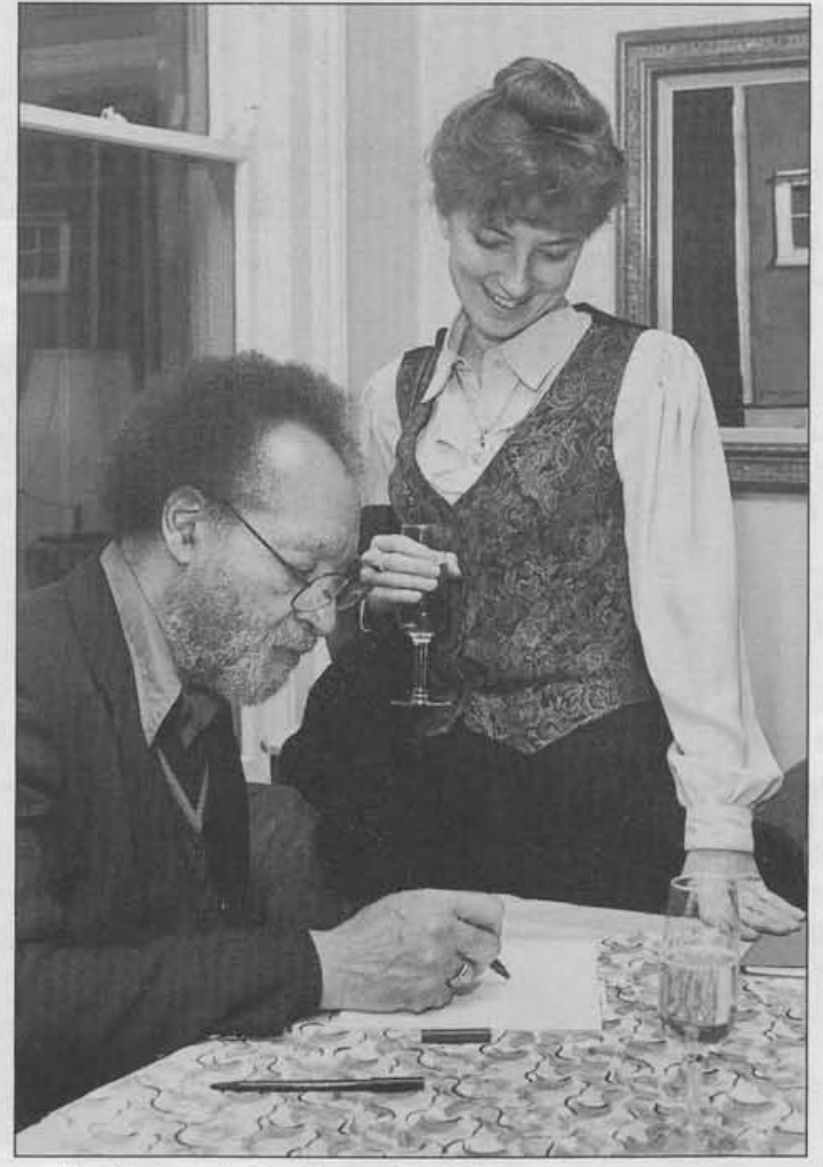

NCSU Poet-in-Residence Gerald Barrax autographs a book after speaking in the 1994 N.C. Writers Series. ries, and other FOL programs. Membership in the Friends of the Library has grown from around 250 a decade ago to 1,400 members today. Annual gifts during this period increased nearly fourfold. The library endowment has grown an average of more than $30 \%$ annually in the last ten years, and the number of individual endowments leapt from one to over 40 , established not only by FOL members and supporters, but also by N.C. State's own faculty, students, and staff. Their actions have clearly been affected by the library's growing public relations program.

Concurrent with the Author-inResidence program, the NCSU Libraries created the North Carolina Writers Series. The idea again grew out of library director Susan Nutter's conviction that, in a state blessed with an abundance of literary talent, the library is a natural partner in promoting that talent. Even self-designated "literary carpetbaggers" like professor and writer Robin Hemley could exclaim, "For God's sake, what other state has the number of writers striking hardcover deals or a publisher like Algonquin? Or the number and quality of literary maga- 
zines? Or an organization like the North Carolina Writers' Network?"4

In spring 1989, the Friends of the Library initiated an annual four-lecture series spotlighting authors with an affiliation to North Carolina, who were invited to read from their works or to give talks. The first year featured Author of the Year Kaye Gibbons, NCSU English professor Lee Smith, N.C. poet laureate Sam Ragan, and humorist Roy Wilder, Jr. For each event, the library made arrangements with a local bookseller to have copies of the author's works available for purchase. Audience members enjoyed the opportunity to meet the writers and have their books personally autographed at a wine-anddessert reception.

The heady literary ferment of that inaugural year culminated in June 1990, when the NCSU Libraries cosponsored with Gibbons's publisher-the imminently North Carolinian Algonquin Books of Chapel Hill-a reception at the American Library Association's Annual Conference in Chicago. The by-invitation-only event was attended by 200 librarians, writers, publishers, and media representatives. The rollicking evening of readings by four of Algonquin's star authors was cited in the library literature as a "[p]eak experience: Listening to North Carolina writers Kaye Gibbons, Jill McCorkle, Clyde Edgerton, and Larry Brown read from their own work in the lovely setting of Biggs Restaurant." 5 Later in the year, Library Journal's cover story on the North Carolina writers' renaissance described North Carolina as "a state that regards its writers not as celebrities but as part of the landscape." 6

Since then, the N.C. Writers Series has featured nearly 35 novelists, poets, and nonfiction writers. One factor in its success was the timing of its inception. In the late 1980 s, author readings were not as common in the Triangle area as they are today. With increasing interest in the arts and the advent of major bookstore chains, events featuring writers have become routine occurrences. The series now strives to maintain its freshness with a deliberate attempt to incorporate individuals of diverse backgrounds, who write fiction and nonfiction, poetry and prose. The library continues to collect autographed first editions of all its speakers' works and one slot in the series is always reserved for the Author-in-Residence.

While writers and libraries may be a good fit, programs such as the ones described come about only with a great deal of hard work. At the NCSU Libraries, they have succeeded because of the commitment of the library administration and the resources allocated to the enterprise. A full-time librarian serves as director and is aided by a full-time program assistant and part-time student help. Strong support also comes from the Board of Directors, comprised of more than 25 individuals who volunteer their time and energies to help meet the organization's mission of support for the NCSU Libraries. In particular, the Program Committee helps to identify and attract speakers for the N.C. Writers Series. Its members are now considering ways of refocusing the series to attract a wider audience while continuing to publicize the work of writers of all kinds.

In the case of the Author-in-Residence program, a decided factor in its longevity is the popularity of the incumbent. The NCSU Libraries was fortunate to find a person whose writing has elicited praise from the likes of Eudora Welty, whose unforgettable phrase "the life in it, the honesty of thought and eye and feeling and word!" appears on the book jacket of Ellen Foster. Kaye Gibbons is a remarkable individual who, like her own characters, has overcome extreme hardship to achieve a hard-won personal happiness and professional success. The enormously popular Ellen Foster, for example, reflects elements of Gibbons's own childhood as an orphan and has been selling 3,000 paperback copies a month. Its inclusion in the syllabi of literature classes across the country reflects its appeal and accessibility to a wide range of readers. In Sights Unseen and Frost and Flower; My Life with Manic Depression (So Far), Gibbons reveals her personal battle with a crippling illness. Her works appeal to an audience who respond to her in an intensely personal way. As Robin Hemley noted in 1994, "when Kaye Gibbons left North Carolina for California..., the state seemed to go into shock. I thought a day of mourning might be declared. But then a miracle occured [sic] - she came back home again!"

The NCSU Libraries' experience with its Author-in-Residence is encouraging for other academic libraries that wish to follow suit. There is no shortage of writers, particularly beginning authors who can benefit from the support of an established organization like a library. Libraries should investigate creative ways in which to cultivate special relationships with writers. At the University of Tennessee at Knoxville, the
Hodges Library's newly established Writer in Residence program exemplifies another notable writer-library relationship that emphasizes aspects specific to that locale. According to the first Writer in Residence, Brian Griffin, during its one-year pilot the position offers him fully equipped office space in the Hodges Library, the support of the library organization, and a small stipend. In return, Griffin is committed to writing a book during his tenure and to serving as a literary liaison with the local community. He keeps the library informed about promising writers in Tennessee and the Appalachian area, and makes authors aware of the library as a resource (e.g., as a place to host their readings or as repository for their publications). ${ }^{8}$

As evidence of the NCSU Libraries' success in fusing the thought of Kaye Gibbons with her library role, when an announcement about her selection for Oprah Winfrey's book club appeared on the Web page of Library Journal, the author was prominently described as the NCSU Libraries' Author-in-Residence and a "library devotee." Finally, it is heartwarming for library staff to hear the eloquent testimony of their own Author-in-Residence: "The NCSU Libraries is my haven, the staff a blessing. I have rested my spirit there on the bounty of words." 9

\section{References}

1 Barbara Elleman, comp., Books Change Lives (Chicago: American Library Association, 1994), [37].

2 Manly Wade Wellman, "On Being a North Carolina Writer," North Carolina Literary Review I (Summer 1992): 149150.

3 Barbara Hoffert, "Writers' Renaissance in North Carolina," Library Journal 114 (November 1, 1989): 47.

4 Robin Hemley, "Yankee Writers in North Carolina: Literary Carpetbaggers?" North Carolina Literary Review II (Spring 1994): 129.

5 Graceanne A. DeCandido, "Alarums \& Diversions," Library Journal 115 (August 1990): 24.

6 Hoffert, 46.

7 Hemley, 129.

8 Brian Griffin, telephone conversation with author, February 25, 1999.

9 Kaye Gibbons, [advertisement], NC State 71 (Winter 1999): 56. 


\title{
Backyard Treasure: \\ North Carolina Authors of \\ Books for Children and Young Adults
}

\author{
by Ruth Moose
}

\section{।}

fell in love with James Street in graduate school. Also with Suzanne Newton and Eleanora Tate. You see, my favorite class at the University of North Carolina at Greensboro was children's literature, and I discovered that many of the writers in this magical world lived in North Carolina. Today I teach the writing of children's literature to a new generation of students at the University of North Carolina at Chapel Hill, and North Carolina writers figure prominently in class readings and discussions. They constitute a virtually unrecognized state treasure.

Come with me on a whirlwind tour of North Carolina's literary bounty. We will begin in the Research Triangle area because many of the writers living there have been kind enough to visit my classes. William Hooks, who has published more than fifty books for children and young readers, including Snowbear Whittington (1994), lives a few blocks from the UNCCH campus. In nearby Carrboro is Clay Carmichael, author of Bear at the Beach (1996) and Used-Up Bear (1998). Susie Wilde, who reviews children's books and has written Extraordinary Chester (1988), also lives in the area, as do Mark and Cathy Dubowski, who have between them published an amazing eighty-five books. Max Steele, former head of the Creative Writing Program at UNCCH, wrote the beloved The Cat and the Coffee Drinkers (1969). Also in Chapel Hill is Janice May Udry, author of many picture books including one Caldecott winner, A Tree is Nice (1956). Louise Haas, author of Rosey in the Present Tense (1999), a story for middle readers, recently moved to Fearrington Village, south of Chapel Hill. Sarah Dessen, also on the UNCCH faculty, is author of two novels for young adults, That Summer (1996) and Someone Like You (1998). Nancy Tilly, whose novel Golden Girl won the AAUW award in 1986, lives nearby, as does Frances Davis, author of Frank Lloyd Wright: Maverick Architect (1996).

Maureen Wartski, author of $A$ Long Way from Home (1980) and five other books for young adults, and Suzanne Newton, winner of five North Carolina AAUW awards for Best Juvenile Book, including M.V. Sexton Speaking (1981), live in Raleigh. Also in Raleigh is Belinda Hurmence, author of Tancy (1984) and other books for young adults.

In Durham live Jackie Ogburn, who wrote Jukebox Man (1998), and Catherine Petroski, author of The Summer That Lasted Forever (1984). Mesa Somer, also in Durham, syndicates a newspaper exclusively for children, Kidsville News, and is the author of Night of the Five Aunties (1996).

Greensboro is home to a number of authors, including Carole Boston Weatherford, author of Juneteenth Jamboree (1995), Me and the Family Tree (1996), and Sink or Swim: Black Life Sav- ers of the Outer Banks (1999); Stephanie Greene, who wrote Owen Foote: Second Grade Strongman (1996); and Donna Jacobs, whose baby picture books are gems. Also in Greensboro are Orson Scott Card, whose science fiction novels include Ender's Game (1985), which was named a Best Book for Young Adults, and Mary Jarrell, whose Knee Baby (1973) I read aloud to my classes. Her late husband, Randall Jarrell, published Juniper Tales, which won the AAUW Award in 1964. Mary Pope Osborne, who grew up in Greensboro but now lives in New York City, writes the popular Magic Tree House Mystery Series, as well as other books for children, including Moonhorse (1991).

In Charlotte are Kenn and Joanne Compton, whose Ashpet, An Appalachian Tale (1994), is a class favorite, and Helen Copeland, who has written several books for boys, including This Snake is Good (1968). Betsy Byars, born in Charlotte but now living in Clemson, SC, won the Newbery Award for her Summer of the Swans (1970).

In eastern North Carolina is Glen Rounds, over ninety years old, who lives in Southern Pines and is the author and illustrator of many books of tall tales, including The Snake Tree (1966) and Wild Appaloosa (1983). Eleanora Tate, now living on the coast, wrote the young adult novel, The Secret of Gumbo Grove (1987), which has become a classic. Lois Duncan, a newcomer to the Outer Banks, has published thirty-five 
books. One, I Know What You Did Last Summer (1990), was recently made into a movie.

To the west is Gloria Houston, born in Spruce Pine but now living in Florida, who still maintains North Carolina connections. Her Caldecott Honor Book, The Year of the Perfect Christmas Tree (1994), and My Great-Aunt Arizona (1992) are wonderful choices for reading aloud. Author and illustrator Gail Hailey, who now lives in Boone, received a Caldecott Medal for her 1970 African tale A Story, A Story. Doris Buchanan Smith of Hayesville has written seventeen books including The Taste of Blackberries (1973) and Return to Bitter Creek (1986). Bill Brittain, who writes young adult books, lives in Asheville. Sparta is home to Sue Ellen Bridgers, whose nationally recognized writing includes the young adult books Permanent Connections (1987), which is being reprinted by Wilmington's Banks Channel Press, and All We Know of Heaven (1996).

In Writers' Heaven, which is where I'm sure they are, are Guy Owen, who wrote Journey for Joedel (1970), a young adult novel set in the state's tobacco region, and James Boyd, whose novel Drums (1928) was illustrated by N.C. Wyeth. In addition to her novels for adults, Bernice Kelly Harris wrote a children's book, The Santa on the Mantel (1964). Ina Forbus lived in Durham and wrote for children. Her books include The Magic Pin (1956). Elizabeth Smith, born in Charlotte, published ten books for children and young adults, including biographies of first ladies, women aviators (Coming Out Right: The Story of Jacqueline Cochran, 1991), and picture books. Inglis Fletcher of Edenton was known for her historical novels, but few know that her first novel, The White Leopard (1931) was a selection of the Junior Literary Guild, serialized in Boy's Life, and made into a movie. Nell Wise Wechter wrote five books for young adults set on the coast of North Carolina; one of them, Taffy of Torpedo Junction (1957), was recently reprinted by the University of North Carolina Press. Julia Montgomery Street began her writing career after she became a grandmother and went on to write four novels, each based on some aspect of North Carolina history. James Street's boy and dog books, The Biscuit Eater (1939) and Goodbye, My Lady (1954) were best sellers later made into popular movies. Manly Wade Wellman wrote an astonishing eighty books during his career, almost half of them young adult histories based on events in the history of North Carolina. He received an AAUW award for Rifles at Ramsour's Mill (1961). In the High Country lived Ellis Credle, who wrote the Appalachian story Down, Down the Mountain (1934); Richard Chase of Beech Mountain, whose book The Jack Tales (1943) is always popular; and Boone's Vera and Bill Cleaver, authors of the classic Where the Lillies Bloom (1969), which was adapted to film by Walt Disney.

Stephen Roxburgh, editor of Cricket Magazine and president and publisher of Front Street Books, lives in Asheville. Front Street recently published The Facts Speak for Themselves by young adult award-winning author Brock Cole. In Wilmington, Banks Channel Books is publishing its first young adult novel, Takedown, a book by E. T. Benjamin about high school wrestling. Dream Girl, a magazine for girls ages eleven to fifteen edited by Frances Dowell, is published in Carrboro, as is Shoofly, an audio magazine for children.

The Society of Children's Book
Writers and Illustrators has several active chapters in North Carolina that hold workshops around the state. In May 1999 the SCBWI sponsored a month-long show of work by children's book illustrators of the Carolinas at the Chapel Hill Museum, with corresponding programs and speakers.

Authors of books for children and young adults are universally overlooked and under-reviewed, but things are slowly changing. In 1998 William Hooks became the first children's author to receive a Distinguished Alumni Award from UNCCH. Beginning in the year 2000, the North Carolina Writers Network will hold an annual competition for writers of stories for middle readers named for Elizabeth Smith and sponsored by her husband, Edward $\mathrm{H}$. Smith of Charlotte. North Carolina's writers of children and young adult literature may not be as widely recognized as the state's authors of adult works, but they are known and loved by the children and young adults who are their readers. That's what counts. What is held in the heart, always holds true.

\section{AвOUt THE AUthors}

\section{Alice R. Cotten \\ Education: B.A., UNCG; M.A., UNCCH \\ Position: Reference Historian, North Carolina Collection, UNCCH}

\section{Jinnie Y. Davis}

Education: A.B., A.M.L.S., University of Michigan; M. Hispanic Studies, Auburn University; Ph.D., Indiana University

Position: Assistant Director for Planning and Research, NC State University

\section{Dorothy Hodder}

Education: A.B., M.S.L.S., UNCCH

Position: Public Services Librarian, New Hanover County Public Library

\section{William K. Finley}

Education: B.A., The College of William and Mary; M.A., University of Kentucky; M.L.S., University of South Carolina; Ph.D., Duke University

Position: Special Collections Librarian, Jackson Library, UNCG

\section{Eileen McGrath}

Education: B.A., Saint Lawrence University; M.A., Vanderbilt University; M.L.S., George Peabody College

Position: Collection Management Librarian, North Carolina Collection, UNCCH

\section{Ruth Moose}

Education: B.A., Pfeiffer College (now University); M.L.S., UNCG

Position: Author; Lecturer, Creative Writing Program, UNCCH

Maurice C. Y ork

Education: M.A., M.S.L.S., UNCCH

Position: North Carolina Librarian, Joyner Libreary, East Carolina University 


\title{
North Carolina's \\ Award-Winning Creative Writers
}

\begin{abstract}
North Carolina's most well-known literary awards are given each year at the annual meeting of the North Carolina Literary and Historical Association. A list of the winners in each creative writing category provides a glimpse of the names of some of the state's best writers, along with titles of their outstanding books. The Web site of the North Carolina Collection at the library at the University of North Carolina at Chapel Hill $<\mathrm{http} / / / \mathrm{www}$.lib.unc.edu/ncc/> maintains an up-to-date list of these winners, as well as a list of the winners of the Mayflower Cup, awarded each year for the best work of nonfiction. The list below is taken from that Web site.
\end{abstract}

Roanoke-Chowan Award Winners Since 1953 sponsor: Roanoke-Chowan Group of Writers and Allied Artists category: Poetry

1953 Frank Borden Hanes. Abel Anders

1954 Thad Stem, Jr. The Jackknife Horse

1955 No award

1956 Helen Bevington. A Change of Sky

1957 Dorothy Edwards Summerrow. Ten Angels Swearing

1958 Paul Bartlett. Moods and Memories

1959 Olive Tilford Dargan. The Spotted Hawk

1960 Carl Sandburg. (Total of his work)

1961 Carl Sandburg. Wind Song

1962 Helen Bevington. When Found, Make a Verse Of

1963 Herman Salingar. A Sigh Is the Sword

1964 E. S. Gregg. Reap Silence

1965 Randall Jarrell. The Lost World

1966 Thad Stem, Jr. Spur Line

1967 Walter Blackstock. Leaves Before the Wind

1968 Paul Baker Newman. The Cheetah and the Fountain

1969 Guy Owen. The White Stallion, and Other Poems

1970 Charles Edward Eaton. On the Edge of the Knife

1971 Paul Baker Newman. The Ladder of Love

1972 Fred Chappell. The World Between the Eyes

1973 Ronald H. Bayes. The Casketmaker

1974 Campbell Reeves. Coming Out Even

1975 Marian Cannon. Another Light

1976 Fred Chappell. River: A Poem

1977 Norman W. MacLeod. The Distance
1978 Mary Louise Medley. Seasons and Days

1979 Fred Chappell. Bloodfire: A Poem

1980 Fred Chappell. Wind Mountain: a Poem

1981 James Applewhite. Following Gravity

1982 Thomas Heffernan. The Liam Poems

1983 Reynolds Price. Vital Provisions

1984 Betty Adcock. Nettles

1985 Fred Chappell. Castle Tzingal

1986 James Applewhite. Ode to the Chinaberry Tree and Other Poems

1987 Charles Edward Eaton. New and Selected Poems, 1942-1987

1988 Lochlin Walker. Musings While Adrift

1989 Fred Chappell. First and Last Words

1990 Sam Ragan. Collected Poems of Sam Ragan

1991 Charles Edward Eaton. A Guest on Mild Evenings

1992 Julie Suk. The Angel of Obsession

1993 James Applewhite. A History of the River

1994 Judy Goldman. Wanting to Know the End

1995 Robert Watson. The Pendulum

1996 Fred Chappell. Spring Garden: New and Selected Poems

1997 James L. Seay. Open Field, Understory: New and Selected Poems

1998 Kathryn Stripling Byer. Black Shawl 
1953 Ruth and Latrobe Carroll. Peanut

1954 Mebane Holoman Burgwyn. Penny Rose

1955 Ruth and Latrobe Carroll. Digby, the Only Dog

1956 Julia Montgomery Street. Fiddler's Fancy

1957 Nell Wise Wechter. Taffy of Torpedo Junction

1958 Ina B. Forbus. The Secret Circle

1959 Thelma Harrington Bell. Captain Ghost

1960 Jonathan Daniels. Stonewall Jackson

1961 Glen Rounds. Beaver Business

1962 Manley Wade Wellman. Rifles at Ramsour's Mill

1963 Julia Montgomery Street. Dulcie's Whale

1964 Randall Jarrell. The Bat-Poet

1965 Alexander Key. The Forgotten Door

1966 Richard Walser and Julia Montgomery Street. North Carolina Parade, Stories of History and People

1967 Glen Rounds. The Snake Tree

1968 Neal F. Austin. A Biography of Thomas Wolfe

1969 Mary Lina Bledsoe Gillet. Bugles at the Border

1970 Mebane Holoman Burgwyn. The Crackajack Pony

1971 Suzanne Newton. Purro and the Prattleberries

1972 No award

1973 Barbara M. Parramore. The People of North Carolina

1974 Suzanne Newton. C/o Arnold's Corners

1975 Alexander Key. The Magic Meadow
1976 Glen Rounds. Mr. Yowder and the Lion Roar Capsules 1977 Ruth White Miller. The City Rose

1978 Suzanne Newton. What Are You Up To, William Thomas?

1979 Suzanne Newton. Reubella and the Old Focus Home

1980 Caroline B. Cooney. Safe As the Grave

1981 No award

1982 Suzanne Newton. M. V. Sexton Speaking

1983 Glen Rounds. Wild Appaloosa

1984 Belinda Hurmence. Tancy

1985 Catherine Petroski. The Summer That Lasted Forever

1986 Nancy Tilly. Golden Girl

1987 Sue Ellen Bridgers. Permanent Connections

1988 Lila Hopkins. Eating Crow

1989 Belinda Hurmence. The Nightwalker

1990 Lila Hopkins. Talking Turkey

1991 Suzanne Newton. Where Are You When I Need You?

1992 Bill Brittain. Wings

1993 Christina Askounis. The Dream of the Stone

1994 Joanne Compton. Ashpet: An Appalachian Tale

1995 Joanne and Kenn Compton. Sody Sallyratus

1996 William Hooks. Freedom's Fruit

1997 Gloria Houston. Littlejim's Gift: An Appalachian Christmas Story

1998 Jacqueline Ogburn. Jukebox Man

Sir Walter Raleigh Award Winners Since 1952

sponsor: The Historical Book Club of Greensboro category: Fiction

1952 Paul Green (for Outstanding Literary Achievement)

1953 Inglis Fletcher (for Outstanding Literary Achievement) Frances Gray Patton. The Finer Things of Life

1954 Ovid Williams Pierce. The Plantation

1955 Frances Gray Patton. Good Morning, Miss Dove

1956 Frances Gray Patton. A Piece of Luck

1957 Doris Betts. Tall Houses in Winter

1958 Betty Smith. Maggie-Now

1959 Ernest Frankel. Band of Brothers

1960 Ovid Williams Pierce. On a Lonesome Porch

1961 Frank Borden Hanes. The Fleet Rabble

1962 Reynolds Price. A Long and Happy Life

1963 Richard McKenna. The Sand Pebbles

1964 John Ehle. The Land Breakers

1965 Doris Betts. The Scarlet Thread

1966 Heather Ross Miller. Tenants of the House

1967 John Ehle. The Road

1968 Sylvia Wilkinson. A Killing Frost

1969 Bynum Shaw. The Nazi Hunter

1970 Guy Owen. Journey for Joedel

1971 John Ehle. Time of Drums

1972 Daphne Athas. Entering Ephesus

1973 Fred Chappell. The Gaudy Place

1974 Doris Betts. Beasts of the Southern Wild and Other Stories

1975 John Ehle. The Changing of the Guard
1976 Reynolds Price. The Surface of Earth

1977 Sylvia Wilkinson. Shadow of the Mountain

1978 Mary Sheppard. All Angels Cry

1979 Daphne Athas. Cora

1980 Guy Owen. The Flim-Flam Man and Other Stories

1981 Reynolds Price. The Source of Light

1982 Lee Zacharias. Lessons

1983 Lee Smith. Oral History

1984 Reynolds Price. Private Contentment

1985 John Ehle. Last One Home

1986 Reynolds Price. Kate Vaiden

1987 Marianne Gingher. Bobby Rex's Greatest Hit

1988 Lawrence Rudner. The Magic We Do Here

1989 Lee Smith. Fair and Tender Ladies

1990 Allan Gurganus. Oldest Living Confederate Widow Tells All

1991 Kaye Gibbons. A Cure for Dreams

Peter Turchi. Magician

1992 Angela Davis-Gardner. Forms of Shelter

1993 John Russell. Favorite Sons

1994 Michael Parker. The Geographical Cure: Novellas and Stories

1995 Tim McLaurin. Cured by Fire

1996 G. Dan Gearino. What the Deaf-Mute Heard

1997 Charles Frazier. Cold Mountain

1998 Clyde Edgerton. Where Trouble Sleeps 


\section{Little Magazines in North Carolina}

One sign that creative writing is flourishing in a state is the presence of "little magazines." These publications, many times out of the mainstream or associated with academic institutions, often publish new writers, minorities, or alternative types of writing, bringing these new voices to the attention of the literary establishment. The following list of little magazines in North Carolina, adapted from the fifth edition (1999) of North Carolina's Literary Resources Guide and published by the North Carolina Writers' Network, and is used through the courtesy of Linda Hobson, Director of the Network. Additional information about little magazines can be found in issues of the North Carolina Literary Review. The North Carolina Collection in the University of North Carolina at Chapel Hill Library actively collects little magazines.

Copies of North Carolina's Literary Resources Guide are available from the North Carolina Writers' Network, P.O. Box 954, Carrboro, NC 27510. Cost is $\$ 8.00$ for network members, $\$ 10$ for non-members.

North Carolina Literary Magazines and Presses is a literary association of North Carolina's nonprofit little magazines and small presses. Members of this group are indicated with an asterisk.

When requesting information from a magazine or press, remember to include a self-addressed stamped envelope (SASE).

\section{*Asheville Poetry Review}

Keith Flynn, managing ed., PO Box 7086, Asheville, NC 28802

The Asheville Poetry Review is a biannual, international journal established in 1994 that focuses on poetry, translations, and reviews. It prints 600 copies per issue. Subscriptions: $\$ 22.50 /$ year; $\$ 43.50 / 2$ years; $\$ 13 /$ single issue.

Brightleaf: A Southern Review of Books

David S. Perkins, ed. and publ., 303 Blake St., Ste. 203, Raleigh, NC 27601

e-mail: <dperkins@mindspring.com>; Web site: <www.brightleaf-review.com>

Established in 1997, Brightleaf is a regional book review published quarterly. Includes reviews by and about Southern writers and special profiles, as well as regular columns and departments that comment on the literary arts in the South. Subscription: \$25/year.

*Carolina Quarterly

Robert West, ed., CB\# 3520, Greenlaw, UNC-Chapel Hill

Chapel Hill, NC 27599-3520

The Carolina Quarterly is a triannual publication established in 1948. It features fiction and poetry by new and established writers, also graphic art, reviews and nonfiction, and prints 1,100 copies. Subscription: \$12/year.

*Coastal Plains Poetry

Nina Wicker, Committee Chair, 4318 Minter School Rd., Sanford, NC 27330

Coastal Plains Poetry, Eleanor R. May, ed., established in 1992, is published annually each fall, and features both emerging and established writers. Circulation is 350 copies. Issues sell for $\$ 6$.

Creative Loafing

John Grooms, ed., PO Box 241988, Charlotte, NC 28224-1988

e-mail: <john.grooms@creativeloafing.com>; Web site: <www.creativeloafing.com/charlotte/newstand/current> Creative Loafing, a weekly newspaper, was established in 1987 and prints 50,000 copies. Subscription: \$26/year. 
${ }^{*}$ Crucible

Terrence L. Grimes, ed., Kathy James, asst. ed., Barton College, Wilson, NC 27893

e-mail: <tgrimes@e-mail.barton.edu>

The Crucible, an annual publication established in 1964, features fiction and poetry with an emphasis on North

Carolina writers. Prints 500 copies. Subscription: \$6/year.

${ }^{*}$ DoubleTake Magazine

1317 W. Pettigrew St., Durham, NC 27705

e-mail: <dtmag@aol.com>; Web site: <www.doubletakemagazine.org>

DoubleTake Magazine is a quarterly publication established in 1995; it prints 65,000 issues. DoubleTake publishes

fiction, nonfiction, essays, poetry, and photography representing the breadth and depth of the extraordinary

events of everyday life. Subscription: \$24/year. DoubleTake will move its offices to Cambridge, Massachusetts, in

Summer 1999.

Dream/Girl

Frances Dowell, ed., PO Box 639, Carrboro, NC 27510

e-mail: <fdowell@mindspring.com>

Dream/Girl magazine seeks to encourage creative genius in girls age 11-15. Includes articles on arts and crafts, interviews with artists, book and music reviews. Circulation is 2,000. Subscription: $\$ 12 /$ four issues.

Ex Umbra

Andrew Williams, adv., Dept. of English, N.C. Central University, Durham, NC 27707

Ex Umbra annually publishes the creative efforts of NCCU students, staff, and alumni and prints 2500 copies.

FIBERARTS Magazine

Nancy Orban, ed., 50 College St., Asheville, NC 28801

FIBERARTS magazine was established in 1976 and provides information and inspiration for textile artists; it is published five times a year.

Front Striker Bulletin

Bill Retskin, owner, PO Box 18481, Asheville, NC 28814

e-mail: <bill@matchcovers.com>; Web site: <www.matchcovers.com>

Published quarterly, the Front Striker Bulletin promotes and prints articles on match cover collecting. Established in 1986 , the magazine has a circulation of 550 . Subscription: $\$ 25 /$ year.

GreenPrints: "The Weeder's Digest"

Pat Stone, ed., PO Box 1355, Fairview, NC 28730

GreenPrints, published quarterly, endeavors to share the human side of gardening through personal garden stories and essays. Circulation is 10,000 . Subscription: $\$ 17.97 /$ year.

\section{*Greensboro Review}

Jim Clark, ed., English Department, 134 Mclver, UNC-Greensboro, PO Box 26170, Greensboro, NC 27402-6170 e-mail: <clarkj@fagan.uncg.edu>

The Greensboro Review, a biannual publication established in 1966, features poetry and fiction by writers nationwide. Prints 1,000 copies. Subscriptions: \$10/year; \$25/3 years.

*International Poetry Review

Mark Smith-Soto, ed., Dept. of Romance Languages, UNC-Greensboro, Greensboro, NC 27402-6170

International Poetry Review, a biannual publication established in 1975, features poems in translation and originally composed in English. It prints 300 copies. Subscriptions: $\$ 10 /$ year, $\$ 18 / 2$ years, $\$ 25 / 3$ years, $\$ 100 /$ life, $\$ 5 /$ sample.

Journal of African Travel-Writing

Amber Vogel, ed., P.O. Box 346, Chapel Hill, NC 27514

The Journal of African Travel-Writing is a semi-annual publication established in 1996. It presents and explores accounts of African travel in all literary genres and prints 600 plus copies. Subscription: \$10/year.

\section{Kshanti Literary/Arts Review}

Hilde Weiseit, co-ed., PO Box 1644, Carrboro, NC 27510

e-mail: <editors@literary.org>; Web site: <www.literary.org>

Established in 1997 Kshanti Literary/Arts Review publishes poetry, fiction, photography, essays, interviews, and reviews by new and established writers and artists. Published continuously on the Web, Kshanti is distributed in print biannually. Subscription: \$22.50/year.

\section{Lonzie's Fried Chicken Literary Magazine}

E.H. Goree, ed. and publ., PO Box 189, Lynn, NC 28750

Established in 1998, Lonzie's Fried Chicken Literary Magazine publishes accessible Southern fiction and poetry, strives to offer the best in regional fiction and poetry and to give new writers a voice. Published twice yearly. Subscriptions: $\$ 12.95 /$ year; $\$ 23.95 / 2$ years.

The Lyricist

David Tillman, ed. staff, PO Box 220, Buies Creek, NC 27506

Established in 1968, published annually with a circulation of 1000 copies, Lyricist publishes poetry by North

Carolina poets. Subscription: \$3/year. 
*Mount Olive Review

Pepper Worthington, ed., Mount Olive College, 634 Henderson St., Mount Olive, NC 28365

Mount Olive Review, an annual publication established in 1987, features theme-related scholarly articles, poems, short stories, book reviews, interviews, and essays. Subscription: \$25/year.

*North Carolina Literary Review

Thomas E. Douglass, ed., English Dept., East Carolina University, Greenville, NC 27858-4353

North Carolina Literary Review, an annual magazine established in 1992, features articles and essays by and about

NC writers, literature, culture, and history. Circulation 1200 . Subscription $\$ 17 /$ year; $\$ 31 / 2$ years.

North Carolina Review of Books

Mark W. Hornberg, ed., PO Box 10443, Raleigh, NC 27605

e-mail: <funk2@ix.netcom.com>

Founded in 1998, NCRB is free and is distributed throughout the state at bookstores, libraries, coffee shops, and restaurants. Its goal is to provide an alternative to the academic approach to book reviews and to offer an eclectic mix of frequently overlooked literary genres.

*Obsidian II: Black Literature in Review

Afaa M. Weaver, ed., Dept. of English, NCSU, Box 8105, Raleigh, NC 27695-8105

Obsidian II, a biannual publication established in 1975, features fiction and poetry by Black writers worldwide and includes criticism of the work of Black writers by commentators of all races. It prints 500 copies. Subscriptions: $\$ 17.40 /$ year; $\$ 29.80 / 2$ years.

Our State

Mary Ellis, ed., PO Box 4552, Greensboro, NC 27404

Our State, a monthly magazine about North Carolina, was established in 1933 and has a circulation of 35,000. It celebrates North Carolina travel, history, and folklore.

Parting Gifts

Robert Bixby, ed. and publ., 3413 Wilshire Dr., Greensboro, NC 27408

e-mail: <rbixby@aol.com>; Web site: <www.users.aol.com/marchst>

Parting Gifts, a semi-annual poetry and fiction literary magazine, was established in 1988. Also publishes Fatal

Embrace an electronic magazine (Web site: <users.aol.com/rbixby/fatal_embrace/fe11.html>.

\section{Broadfoot's has TWO Locations Serving Different Needs}

\section{Broadfoot's of Wendell}

6624 Robertson Pond Road Wendell, NC 27591 Phone: (800) 444-6963 Fax: (919) 365-6008

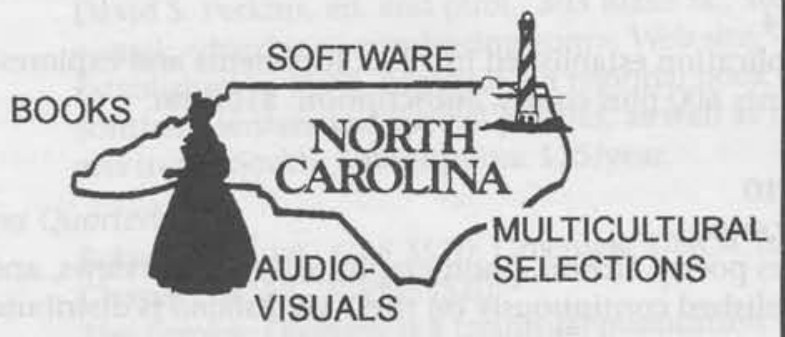

Spring \& Fall Catalogs Are you on our mailing list?

Tar Heel Treasures for

natives \& newcomers young \& old

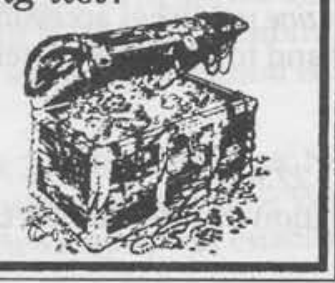

Broadfoot Publishing Company

1907 Buena Vista Circle Wilmington, NC 28405

Phone: (800) 537-5243 Fax: (910) 686-4379

Recent Publications:

The Colonial \& State Records of NC (30 vols.) North Carolina Regiments (5 vols.) Roster of Confederate Troops (16 vols.) Supplement to the Official Records (100 vols.)

Full Color Catalog (free upon request) 
*Pembroke Magazine

Shelby Stephenson, ed., Box 60, UNC-Pembroke, Pembroke, NC 28372

Pembroke Magazine is an annual publication established in 1969, that features fiction, poetry, and essays by

writers nationwide, with a focus on NC writers and literary activity. Prints 600 copies. Subscription: \$5/year.

*Sandhills Review

Stephen Smith, ed., Sandhills Community College, 220 Airport Road, Pinehurst, NC 28374

Sandhills Review, a biannual publication, was established in 1970 as St. Andrews Review. It features poetry, fiction, and plays by emerging and established writers worldwide. Prints 500 copies. Subscriptions: $\$ 14 /$ year; $\$ 25 / 2$ years.

Southern Cultures

Laura Cotterman, managing ed., Center for the Study of the American South, 03B Manning Hall, UNC-CH,

Chapel Hill, NC 27599-3355

e-mail: <csas@e-mail.unc.edu>; Web site: <www.unc.edu/depts/csas/socult/socult.htm>

A quarterly publication, Southern Cultures publishes scholarly essays on the history, politics, folklore, literature, art, and social structures of the South and reviews for an educated (but not necessarily academic) audience.

Established in 1995; circulation is 1,300. Subscriptions: \$28/individual; \$44/institutions.

*Southern Exposure

Pat Arnow, ed., Jo Carson, fiction ed., PO Box 53, Durham, NC 27702

Southern Exposure, established in 1973, is a quarterly magazine that publishes profiles, investigative journalism, art, photos, interviews, reviews, and some poetry and fiction. Membership in the Institute of Southern Studies includes four issues.

*Southern Poetry Review

Ken McLaurin, ed., Advancement Studies Dept., CPCC, Charlotte, NC 28235

Southern Poetry Review is a biannual publication, established in 1958, that features work by young American poets.

Prints 1,100 copies. Subscriptions: $\$ 8 /$ year; $\$ 15 / 2$ years.

*The Sun

Sy Safransky, ed., 107 N. Roberson St., Chapel Hill, NC 27516

The Sun is a monthly magazine, established in 1974. It features essays, interviews, fiction, poetry, and photo-

graphs by emerging and established writers and artists nationwide. Prints 30,000 copies. Subscriptions: $\$ 3.95$ / issue; $\$ 34 /$ year; $\$ 60 / 2$ years.

*Tar River Poetry

Peter Makuck, ed., Dept. of English, East Carolina University, Greenville, NC 27858-4353

Tar River Poetry is a biannual publication, established in 1978, that features poetry by emerging and established writers nationwide. Circulation is 700 . Subscriptions: $\$ 10 /$ year; $\$ 18 / 2$ years.

Taste Full Magazine

Elizabeth K. Norfleet, ed. in chief, PO Box 1712, Wilmington, NC 28402

e-mail: <nctf@taste-full.com>; Web site: <www.taste-full.com>

Established in 1990, Taste Full publishes six times per year and has a circulation of 16,500 . Its concentration is a food-oriented lifestyle focusing on North Carolina culture and history.

*Wellspring

Dave Roberts and Becke Roughton, eds., James Sprunt Community College, PO Box 398, Kenansville, NC 28349 e-mail: <dlrobert@duplinnet.com>; <broughto@duplinnet.com>

Wellspring, an annual publication established in 1991, features poetry, fiction, nonfiction, drawings, and photography by emerging and established writers and artists. Prints 500 copies. $\$ 5 /$ issue.

- Over 21,000 Current \& Backlist Titles

- 19 Years of Service

- "Hands On" Selection

- Pre-School Through Adult

- Discounts up to $70 \%$ Off

- Now Two Adjacent Warehouses

- Sturdy Library Bindings

- $100 \%$ Fill

- Cataloging/Processing Available

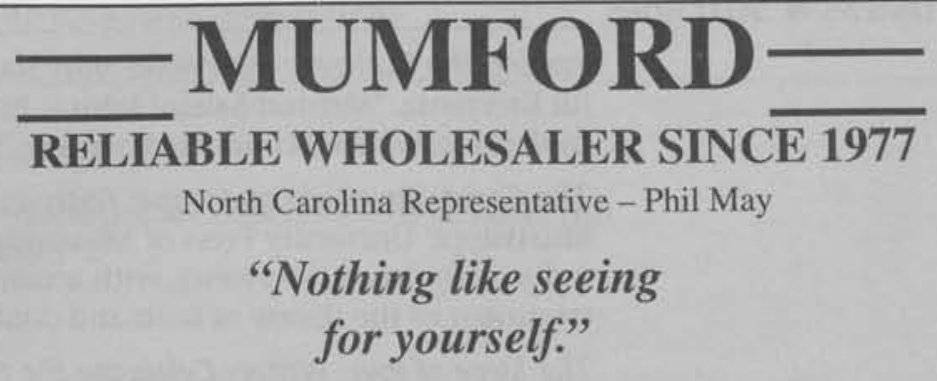

MUMFORD LIBRARY BOOKS, SOUTHEAST, INC.

7847 Bayberry Road • Jacksonville, Florida 32256

(904) 737-2649

FAX: (904) 730-8913

1-800-367-3927 


\title{
A Field Guide to
}

\section{Writers in North Carolina and the South}

\author{
by Dorothy D. Hodder
}

\section{OVERVIEWS}

Literary North Carolina, by Richard Walser with E.T. Malone, Jr. Raleigh: North Carolina Department of Archives and History, 1986.

This brief history begins with the 16th-century explorers and extends to contemporary poets and novelists. Covers historians, children's writers, humorists, science fiction authors, and publishers.

Southern Writers: A Biographical Dictionary, edited by Robert Bain, Joseph M. Flora, and Louis Rubin, Jr. Baton Rouge: Louisiana State University Press, 1980.

Brief biographical sketches of 379 Southern authors, famous as well as obscure. Authors selected generally had to have published at least four books of poetry or fiction, and had to be identified with the South imaginatively as well as geographically.

Contemporary Fiction Writers of the South: A Bio-Bibliographical Sourcebook, edited by Joseph M. Flora and Robert Bain. Westport, Connecticut: Greenwood Press, 1993.

"... a preliminary report on the flurry of good books Southerners have written in the last two or three decades." Forty-nine authors were included, selected by three main criteria: they should have published four books, been reviewed widely, and have achieved critical recognition outside the South.

Contemporary Poets, Dramatists, Essayists, and Novelists of The South: A Bio-Bibliographical Sourcebook, edited by Robert Bain and Joseph M. Flora. Westport, Connecticut: Greenwood Press, 1994.

A companion to Contemporary Fiction Writers of the South.

Contemporary North Carolina Authors. Wendell, North Carolina: Broadfoot's of Wendell, 1989 -. Looseleaf notebook format, one page per author. Includes a photograph, answers to several biographical questions, and a list of works for each author.

Images of the Southern Writer, photographs by Mark Morrow. Athens, Georgia: University of Georgia Press, 1985.

Southern Writers, photos by David G. Spielman, text by William Starr. Columbia: University of South Carolina Press, 1997.

Coffee table collections of photographs of Southern writers, with brief accompanying texts.

INTERVIEWS \& SELECTIONS

Parting the Curtains: Interviews with Southern Writers, by Dannye Romine Powell, photographs by Jill Krementz. Winston-Salem: John F. Blair, Publisher, 1994.

In-depth interviews conducted between 1975 and 1994. Some have appeared in the Charlotte Observer.

The Christ-Haunted Landscape: Faith and Doubt in Southern Fiction, by Susan Ketchin. Jackson, Mississippi: University Press of Mississippi, 1994.

A dozen in-depth interviews, with accompanying fiction selections, all illustrating the literary treatment of the theme of faith and doubt.

The Store of Joys: Writers Celebrate the North Carolina Museum of Art's Fiftieth Anniversary, edited by Huston Paschal. Winston-Salem: North Carolina Museum of Art in Association with John F. Blair, Publisher, 1997.

Forty-five North Carolina writers, selected by a committee chaired by Reynolds Price, each of whom chose a piece of art in the North Carolina Museum of Art, and wrote a story, poem, or essay about it. A Who's Who of NC writers, and a great introduction to the museum. 
Speak So I Shall Know Thee: Interviews with Southern Writers, by William J. Walsh. Asheboro: Down Home Press, 1993.

Thirty-one lengthy interviews with contemporary Southern authors.

Books of Passage: 27 North Carolina Writers on the Books That Changed Their Lives, edited by David Perkins. Asheboro: Down Home Press, 1997.

And they picked everything from the Bible to Julia Child's Mastering the Art of French Cooking.

Close to Home: Revelations and Reminiscences by North Carolina Authors, edited by Lee Harrison Child.

Winston-Salem: John F. Blair, Publisher, 1996.

Twenty-one authors from North Carolina share memories of home.

Twelve Christmas Stories by North Carolina Writers, and Twelve Poems Too, edited by Ruth Moose.

Asheboro: Down Home Press, 1997.

ANTHOLOGIES

New Stories from the South: The Year's Best, edited by Shannon Ravenel. Chapel Hill: Algonquin Books of Chapel Hill, 1986 -.

Best of the South: From Ten Years of New Stories from the South, selected by Anne Tyler, edited by Shannon Ravenel. Chapel Hill: Algonquin Books of Chapel Hill, 1996.

Our Words, Our Ways: Reading and Writing in North Carolina, by Sally Buckner. Durham: Carolina Academic Press, 1991.

Comprehensive 7th grade textbook with a wide selection of NC authors. Includes selections from their works, brief biographies, and photos.

The Rough Road Home: Stories by North Carolina Writers, edited by Robert Gingher. Chapel Hill: University of North Carolina Press, 1992.

Cardinal: A Contemporary Anthology of Fiction and Poetry by North Carolina Writers, edited by Richard Krawiec, poetry editor Paul Jones. Wendall, North Carolina: Jacar Press, 1986.

The Language They Speak is Things to Eat: Poems by Fifteen Contemporary North Carolina Poets, edited by Michael McFee. Chapel Hill: University of North Carolina Press, 1994.

No Hiding Place: Uncovering the Legacy of Charlotte Area Writers, edited by Frye Gaillard, Amy Rogers and Robert Inman. Asheboro: Down Home Press, in association with the Public Library of Charlotte and Mecklenburg County, 1999.

Pete \& Shirley: The Great Tar Heel Novel, edited by David Perkins. Asheboro: Down Home Press, 1995. A serial novel, each chapter being the work of a different author. Originally published in the Raleigh News \& Observer.

Periodicals

Brightleaf: A Southern Review of Books. Quarterly. David Perkins, Editor and Publisher. Raleigh: Brightleaf Publishing Company, 1997 -.

North Carolina Literary Review: NCLR. Semiannual/annual. Greenville, North Carolina: East Carolina University Department of English and the North Carolina Literary and Historical Assoc., 1992 - .

North Carolina Libraries, quarterly journal of the North Ccarolina Library Association. Each issue includes book reviews.

The Writers' Network News, a bimonthly publication for members of the NC Writers' Network. Articles, calendar, and ads for classes, workshops, writers' groups, contests, and opportunities for publication.

N.C. Poetry Society, a quarterly newsletter.

News \& Observer [Raleigh] Sunday edition includes book reviews.

Web Pages

North Carolina Bookstore

<http://www.mindspring.net/ freedom $1 /$ ncbooks>

North Carolina Writers in the Southern Historical Collection, UNC-Chapel Hill

<http://cadmus.lib.unc.edu/mss/writers>

North Carolina Writers' Network

<http://www.ncwriters.org/>

Brightleaf: A Southern Review of Books

$<$ http://www.brightleaf-review.com>

Atlanta Journal \& Constitution book page

<http://www.accessatlanta.com/global/local/yall/culture/quill/atoz.html> 


\title{
And What About Thomas Wolfe?
}

\author{
by Alice Cotten
}

\section{$\mathbf{T}$} he year 2000 marks the centennial of the birth of Thomas Clayton Wolfe, a likely candidate for the distinction of being North Carolina's most famous author. Libraries and archives can play important roles in what will be a year-long celebration of Wolfe's life and work.

Wolfe, born in Asheville on October 3,1900 , and educated at the University of North Carolina and at Harvard, had a complex relationship with his native state. He wanted to attend either the University of Virginia or Princeton and came to the state university in Chapel Hill in 1916 only under pressure from his father. He attended graduate school at Harvard and lived and wrote in New York from 1924 until his untimely death in 1938. Wolfe's autobiographical novel, Look Homeward, Angel, published in 1929 , brought accusations that the author "spat upon North Carolina and the South," 1 and after its publication he stayed away from the state until 1937. Yet Wolfe grew to love the University of North Carolina during his four years in Chapel Hill, referring to it later as "as close to magic as I've ever been," 2 and he often wrote beautifully and lovingly of his family, friends, and native state.

Though some critics characterize Wolfe's writing as undisciplined and unstructured, a substantial number of scholars affirm Wolfe's place in the canon of American writing. Kurt Vonnegut, when asked to comment on the books he loves most, responded bluntly:

People are proud of holding books in contempt that they've read when they were young and have outgrown. One real injustice in my particular generation is when we got to be forty or so and would remember when we loved Thomas Wolfe's Look Homeward, Angel, which is still a terrific book. Anybody who speaks ill of it, having since outgrown it, is, to use a technical word, an asshole. ${ }^{3}$

The Thomas Wolfe Society, founded in 1979 , is planning a number of events around the state to celebrate the centennial of Wolfe's birth. North Carolina has two cities closely affiliated with Thomas Wolfe. One is Asheville, where Wolfe was born and lived during his childhood, and the other is Chapel Hill, where Wolfe attended the University of North Carolina from 1916 to 1920 . The Thomas Wolfe Memorial State Historic Site is located in Asheville in the boardinghouse that Wolfe's mother operated. Though a fire severely damaged the house in July 1998, and it likely will not be open for a few years, the Visitor Center is open and offers interpretative exhibits, an informative film about Wolfe, a gift shop, and tours and lectures. Pack Memorial Library in downtown Asheville has a good collection of materials by and about Wolfe: books, magazines, photographs, and some letters.

Though the largest cache of Wolfe's literary manuscripts is at Harvard, the North Carolina Collection at the Library of the University of North Carolina at Chapel Hill has an extensive collection of both primary and secondary material by and about Wolfe, including family correspondence, published materials, and some manuscript fragments. Both the historic site and the North Carolina Collection have Web sites featuring some of their Wolfe items. The North Carolina Collection's site reproduces photographs of Wolfe and his family as well as portions of letters that Wolfe wrote. $^{4}$

The Thomas Wolfe Society will hold two official meetings in the year 2000: one in the spring in Chapel Hill, and one in the fall in Asheville. The Society hopes that the United States Postal Service will issue a commemorative stamp for Wolfe. The Playmakers Repertory Company at UNC-CH will open its fall 2000 season with a production of Look Homeward, Angel. The North Carolina English Teacher will devote an issue to Wolfe, which will be a natural link to students and teachers in the community. There will be academic conferences on Wolfe in the United States, Germany, and Italy; other events in Asheville, Chapel Hill, and around the state will be announced soon.

So how do libraries fit in? Libraries can help celebrate Wolfe's Centennial in many ways. One is by ensuring that collections have some basic works by and about Wolfe. (A suggested list follows this article.) Another is by having an institutional membership in the Thomas Wolfe Society, in order to receive The Thomas Wolfe Review twice a year, as well as the annual publication featuring newly published works by Wolfe or items related to Wolfe. ${ }^{5}$ Libraries also may feature Wolfe in exhibits, reading lists, book discussion groups, or programs.

Why should librarians be concerned 
with promoting Thomas Wolfe? This article has already suggested some reasons. Wolfe reveled in the pure joy of books and libraries. In Of Time and the River he wrote about standing in the library of a wealthy man: "all the time the voice of the living books around him seemed to speak to him ... he plundered the living treasures of those shelves. They were all there-the great chronicles ... the keen diaries ... the works of all the poets...- each stood there in his little niche upon the living shelves." 6

Perhaps, though, Louis Rubin helps us answer the question best:

Reading and rereading his books, I was led to feel that ... my own thoughts and emotions might even be worth writing about ... Aren't the Wolfe novels, finally, about being a writer? ... If so, isn't one measure of their literary worth that they communicate the joy of using language so well that many young persons who read them want to write for themselves? ${ }^{7}$

Thomas Wolfe is a major literary figure from North Carolina, one of many writers who were born or who lived in this state. By providing basic works by and about Wolfe, and by encouraging library users to read his writings, librarians can help ensure that North Carolina continues to produce and to nurture talented creative writers for this and future generations.

\section{References}

1 Jonathan Daniels, "Wolfe's First is Novel of Revolt," Raleigh News and $\mathrm{Ob}$ server, October 20, 1929.

2 Thomas Wolfe to Benjamin Cone, July 27, 1929, quoted in The Letters of Thomas Wolfe, ed. Elizabeth Nowell (New York: Charles Scribner's Sons, 1956), 192.

\section{Suggestions for a Basic Thomas Wolfe Collection}

Wolfe's Writings:

Wolfe, Thomas. Look Homeward, Angel. NY: Scribners, 1929.

. Of Time and the River. New York: Scribner's, 1935.

. The Web and the Rock. New York: Harper, 1935.

. You Can't Go Home Again. New York: Harper, 1940.

. The Complete Short Stories of Thomas Wolfe. Edited by Francis E.

Skipp. New York: Collier Books, 1987.

. The Lost Boy: A Novella by Thomas Wolfe. Edited by James W. Clark,

Jr. Chapel Hill: UNC Press, 1992.

The Letters of Thomas Wolfe. Edited by Elizabeth Nowell. New York:

Scribner's, 1956.

The Notebooks of Thomas Wolfe. Edited by Richard S. Kennedy and

Paschal Reeves. Chapel Hill: UNC Press, 1970.

\section{Biography:}

Donald, David Herbert. Look Homeward: A Life of Thomas Wolfe. Boston:

Little, Brown, 1987.

Mitchell, Ted. Thomas Wolfe: A Writer's Life. Asheville: The Thomas Wolfe Memorial State Historic Site, 1997.

Walser, Richard G. Thomas Wolfe, Undergraduate. Durham: Duke University Press, 1977.

\section{Other:}

Idol, John Lane, Jr. A Thomas Wolfe Companion. New York, Westport,

Connecticut: Greenwood Press, 1987.

Kennedy, Richard S. The Window of Memory: The Literary Career of Thomas Wolfe. Chapel Hill: UNC Press, 1962.

3 Kurt Vonnegut, "In the Bone," Biblio 4 (March 1999): 18.

4 The Thomas Wolfe Memorial: <http://home.att.net/ WolfeMemorial/> North Carolina Collection's Thomas Wolfe Collection: <http://lib.unc.edu/ ncc/wolfe/>

Also see: <http://library.uncwil.edu/ wolfe/wolfe.html>

5 For membership information: David Strange, Thomas Wolfe Society Member- ship, P.O. Box 1146 , Bloomington, IN 47402-1146. Institutional memberships are currently $\$ 30.00$ per calendar year.

6 Thomas Wolfe, Of Time and the River (New York: Charles Scribner's Sons, 1935), 587-88.

7 Louis D. Rubin, The Mockingbird in the Gum Tree (Baton Rouge: Louisiana State University Press, 1991), 112.

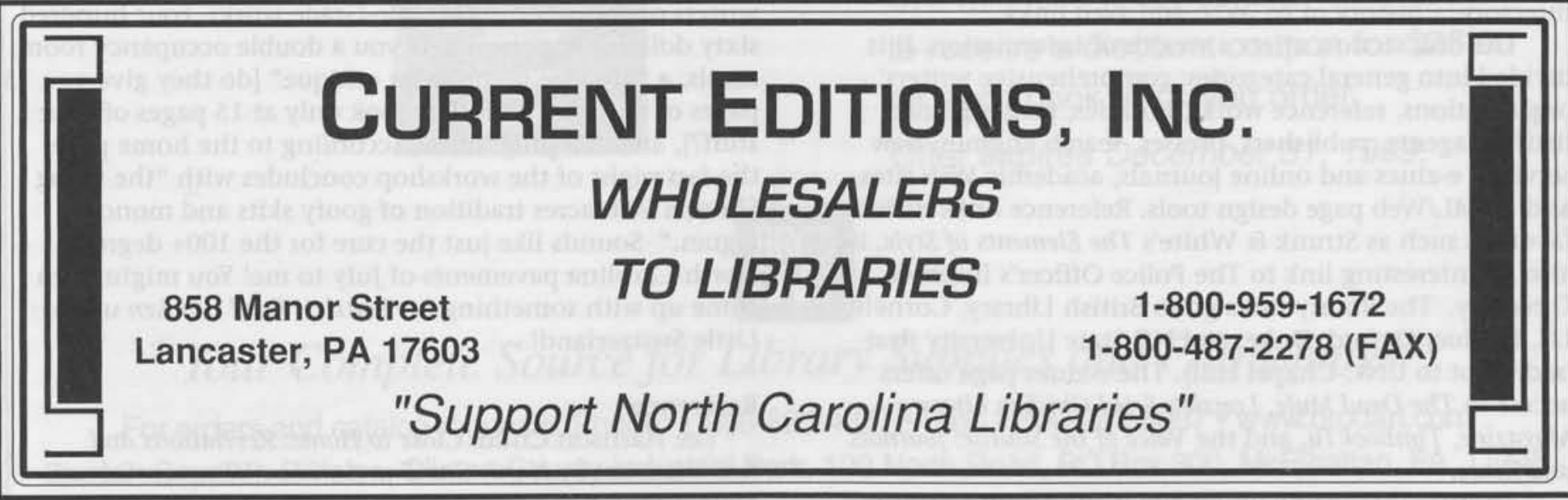




\section{North Carolina Authors}

\section{L} ee Harrison Child writing about North Carolina in Close to Home' states that "one of the things I liked best about our house was the dirt road at the bottom of the hill. Forever gullied and rutted by hard Southern rains, the road was the object of much conflict within the town when I was young." Somehow "forever gullied and rutted" reminds me all too much of my experiences on the modern day Internet, especially when I get an e-mail, "Sorry to report a major fibre cable cut in the Triangle has stopped our traffic" In this column we will visit a number of North Carolina writers' sites on the Internet.

A good place to start is the "North Carolina Writers' Network" at <http://www.ncwriters.org > This peer network was started some fifteen years ago and has become a major factor in the encouragement of writers in North Carolina. Thanks to a recent grant, the North Carolina Writers' Network (NCWN)now has a home office in the 1933 White Cross School on NC 54 west of Chapel Hill. The Network's Motto, "Writing and Reading: Everybody's Art," provides a focus for individual level interaction among state writers. The site has links to membership information, writers' news, library and resource center, literary resource guide, competitions, workshops, conferences, calendars, critique service, readings, Hot Ink (a summer program for teens), press release archive, Center for Business and Technical Writing, the NC Literary Hall of Fame, North Carolina Writers' Network West, outreach programs, FAQ and directory, a history of NCWN, and Web links.

The link section offers a wealth of information. It is divided into general categories: comprehensive writers' organizations, reference works, libraries, funding, job listings, agents, publishers, presses, search engines, new services, e-zines and online journals, academic Web sites, and HTML/Web page design tools. Reference links include favorites such as Strunk \& White's The Elements of Style, but also an interesting link to The Police Officer's Internet Directory. The library links go to British Library, Cornell, LC, Purdue, Oxford, Duke, and NC State University (but oddly not to UNC-Chapel Hill). The e-zines page offers access to The Dead Mule, Lonzie's Fried Chicken Literary Magazine, TimBookTu, and the Voice of the Shuttle: Journals and Zines.

Another interesting writer site is the North Carolina
Women Writers and Their Works home page <http// odyssey.lib.duke.edu/women/ncwwtoc.html $>$. While this is an old site, dating from a Women's Writers Conference in 1992, it appears to have been updated as recently as 1996. Here you will find an excellent essay on "Women and Literary Publishing in North Carolina," together with links to Duke Women's Studies Program pages. "Cities and Roads," a five-issue electronic journal of short fiction, has a homepage that features "short stories showcasing the best of established and emerging writers." At <http:// www.shopthenet.net/poetcorner/cities/> neat pieces of fiction such as "Washing Dishes," "Uncle Daddy," "Face of Adversity," "Distant Sound of Sunshine," "Ice Storm," and "That Standing Man with the OK Sign" are short and very readable. Would-be authors can also submit stories to the editor, Tom Kealey. The main requirement for submission is that the author must be a resident or "visiting student" in North Carolina.

In addition to writers' organizations, online collections, and e-zines, North Carolina is noted for writers' workshops. An interesting one on the Web is the Wildacres Writers Workshop near Little Switzerland which takes place in in July <http://www.wildacres.com $>$. A residential writing workshop housing up to 100 writers "in our lovely lodgetype buildings," the workshop provides coaching in novels, short stories, poetry, and "creative nonfiction." Also this year there is a Wildacres Children's Writers Workshop for writers of Young Adult/Middle-Grade works. Four hundred sixty dollars per person gets you a double occupancy room, meals, a "15 page manuscript critique" [do they give you 15 pages of critique or do they look only at 15 pages of your stuff?], and "all programs." According to the home page, the last night of the workshop concludes with "the Gong Show, a Wildacres tradition of goofy skits and monologues." Sounds like just the cure for the $100+$ degree North Carolina pavements of July to me! You might even come up with something for Lonzie's Fried Chicken up in Little Switzerland!

\section{Reference}

${ }^{1}$ Lee Harrison Child, Close to Home: Revelations and Reminiscences by North Carolina Authors (Winston-Salem: Blair, 1996), $\mathrm{x}$. 


\section{Brodart's Strongest Book Truck Ever!}

\section{"THE SHERMAN TANK"}

Carrying your library books

and equipment to the front lines...

holds up to 500 lbs!
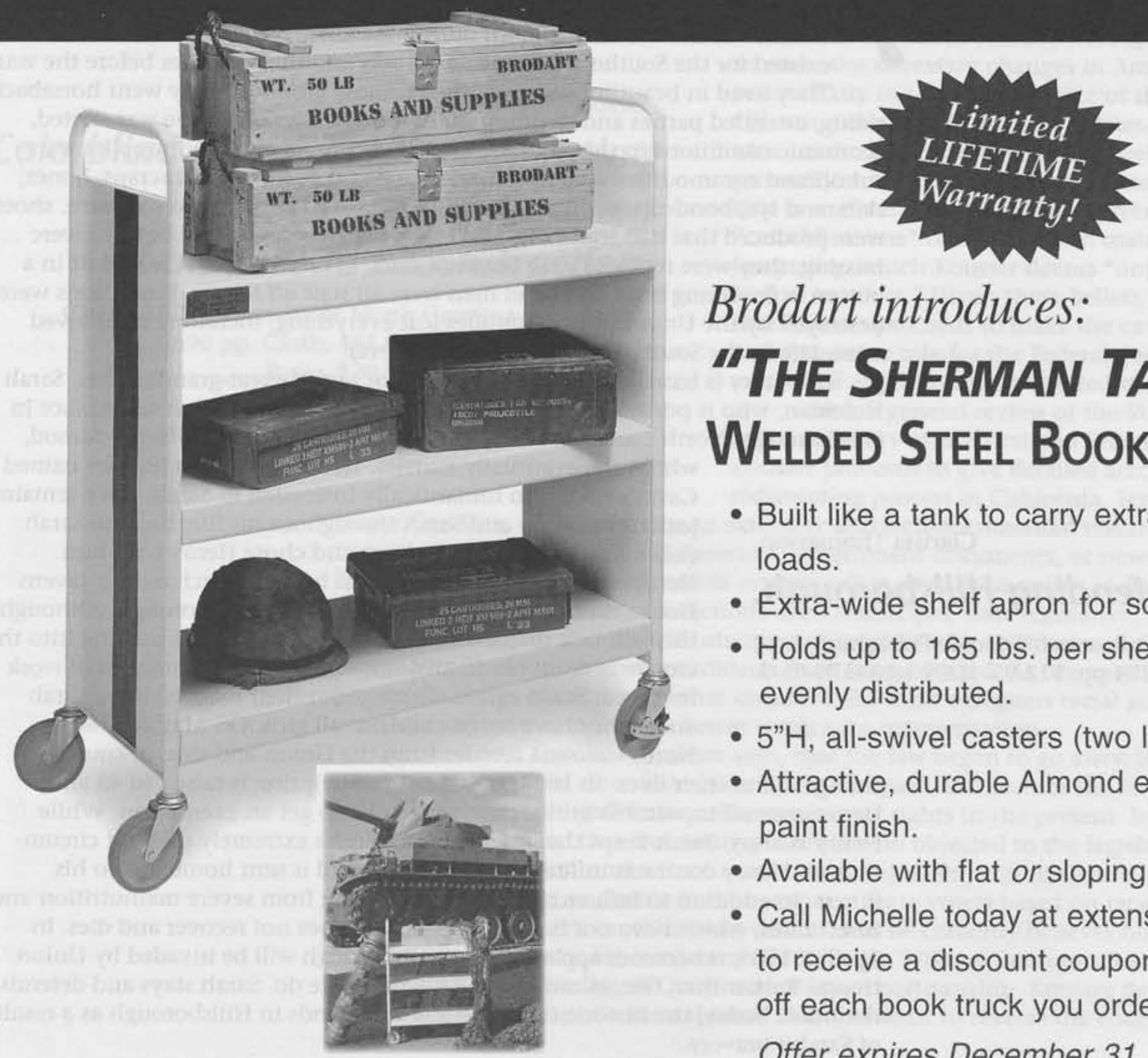

Brodart introduces:

\section{"THE SHERMAN TANK" Welded Steel Book Truck}

- Built like a tank to carry extra heavy loads.

- Extra-wide shelf apron for solid support.

- Holds up to 165 lbs. per shelf, evenly distributed.

- 5"H, all-swivel casters (two locking).

- Attractive, durable Almond epoxy paint finish.

- Available with flat or sloping shelves.

- Call Michelle today at extension 4330 to receive a discount coupon for $\$ 25.00$ off each book truck you order.

Offer expires December 31, 1999.

\section{RRO

Your Complete Source for Library Supplies and Furnishings

For orders and catalog requests: Phone: 1-888-820-4377 • Fax: 1-800-283-6087 • www.brodart.com Brodart Supplies Division, Clinton County Industrial Park, 100 North Road, PO Box 300, McElhattan, PA 17748 


\section{NoRTh CAROLINA}

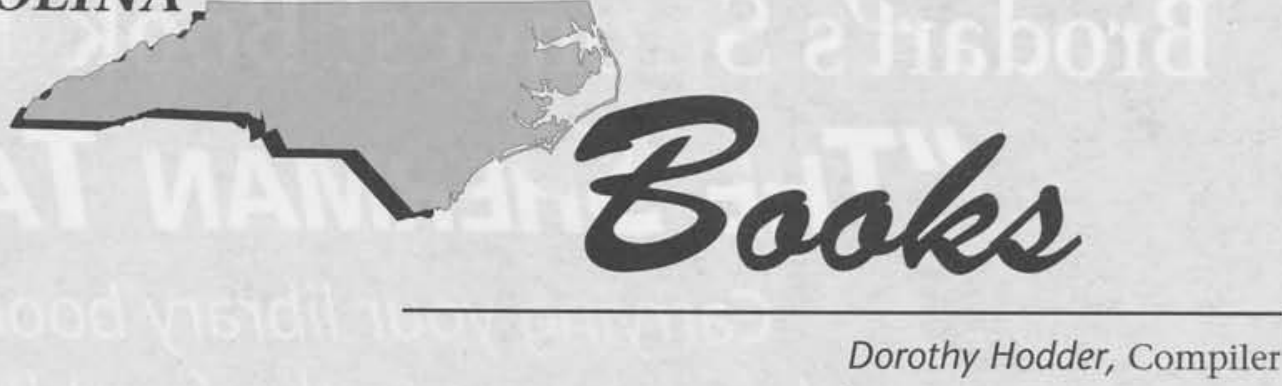

Dorothy Hodder, Compiler

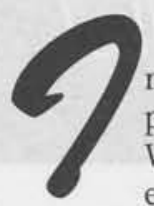

n Defending Hillsborough, Clarissa Thomasson's first novel, the reader is presented with a sharply contrasted portrayal of everyday life in the pre-Civil War South and life in the South during the Civil War. Idyllic conditions existed for the Southern plantation owners and their families before the war. They lived in beautiful homes with grandiose grounds. They went horseback riding, attended parties and weddings, fairs, and picnics. After the war started, economic conditions in the South deteriorated completely. Food supplies were cut off and commodities such as soap had to be made from meat scraps, bones, skin, and lye, bonded together by boiling with ashes. Leather was so scarce, shoes were produced that had leather uppers and wooden soles. When buttons were missing, they were replaced with beans or nuts, or anything that would fit in a button hole. Young boys and older men were all sent off to war. Plantations were destroyed by the Union troops. Families lost everything, including their loved ones. Life in the South would be changed forever.

This story is based on the life of the author's great-great-grandmother, Sarah Holeman, who is portrayed as a strong and courageous woman. It takes place in Hillsborough, North Carolina, and begins with her courtship by Henry Stroud, whom she eventually marries. Henry has a twin brother named Cave, who is also romantically interested in Sarah. Cave remains

Clarissa Thomasson.

\section{Defending Hillsborough.}

Fuquay-Varina, NC: Research Triangle Publishing, Inc., 1998. 284 pp. \$12.95. ISBN 1-884570-85-2. jealous of Henry and Sarah throughout his life, because Sarah did not reciprocate his feelings and chose Henry over him. Henry's dream of many years has been to purchase the Tavern House, an inn and hotel in the town of Hillsborough. Although this will be a major financial burden and means moving into the city away from her family, not to mention the amount of work involved, Sarah agrees. Throughout their married lives, Sarah and Henry have seven children, all girls. On May 20, 1861, North Carolina secedes from the Union and this, of course, changes all of their lives. In 1863, the age of conscription is raised to 45 and Henry goes off to war. His brother Cave manages to get an exemption. While Henry is away, Sarah keeps the hotel running under extremely difficult circumstances. Henry contracts influenza while at war and is sent home due to his illness. In addition to influenza, he is also suffering from severe malnutrition and insect bites, which have not healed properly. He does not recover and dies. In April of 1965 , it becomes apparent that Hillsborough will be invaded by Union troops. Rather than flee, as most of the townspeople do, Sarah stays and defends the hotel. Today, the historic Orange Hotel still stands in Hillsborough as a result of Sarah's bravery.

Thomasson's portrayal of the relationships between Sarah Holeman and Henry and Cave Stroud when they were competing for Sarah's attentions are banal and superficial. Some of the situations seemed ludicrous to me. Sarah never told Henry that Cave was pursuing her, for reasons that are unclear. Thomasson does a better job in the second half of the novel, with her portrayal of Sarah and Henry's true love and devotion for each other. Sarah's character is more fully developed later on in the story and the reader begins to see her intelligence, bravery, and strength. Sarah Holeman was truly a heroic person and Thomasson conveys this successfully. Recommended for school and public libraries. 
any readers are undoubtedly aware of the recent Supreme Court litigation (which is still unresolved) involving North Carolina's congressional "majorityminority" congressional districts. The controversy over these districts, and others like them, is the subject of J. Morgan Kousser's Colorblind Injustice.

Kousser is a professor of history and social science at the California Institute of Technology. He has written numerous books and articles on racial discrimination and voting rights, including The Shaping of Southern Politics: Suffrage Restriction and the Establishment of the One-Party South, 1880-1910, and he has testified as an expert witness in many voting rights and redistricting cases. Some of the cases in which he has been involved are discussed in detail in Colorblind Injustice. (Kousser states this fact in the introduction, so the reader receives fair warning that the narrative is not necessarily an impartial or dispassionate one.)

The book opens by comparing the Reconstruction period after the Civil War to the "Second Reconstruction," a term used to describe the period of civil rights reforms beginning with the Supreme Court's 1954 decision in Brown v. Board of Education. Kousser argues that the reason the Second Reconstruction was more successful than the First in improving minority rights is that the Supreme Court and Congress of the mid-twentieth century were much more inclined

\section{J. Morgan Kousser.}

\section{Colorblind Injustice: Minority Voting Rights and the Undoing of the Second Reconstruction.}

\author{
Chapel Hill: University of North Carolina Press, 1999. \\ 590 pp. Cloth, \$65.00. ISBN 0-8078-2431-3. \\ Paper, \$29.95. ISBN 0-8078-4738-0.
}

to make the necessary changes in American law. Kousser asserts flatly in the first sentence of the book that "[i]nstitutions and institutional rules-not customs, ideas, attitudes, culture, or private behavior-have primarily shaped race relations in America." The book's title is a reference to the idea of government "colorblindness" or neutrality in matters of racial inequality, which Kousser deems "unjust in intent as well as in effect." Given these beliefs, it is not surprising that Kousser proceeds to make the case for a prolonged and aggressive role for the Federal government in matters of apportionment and redistricting.

After a general review of the Voting Rights Act and the history of the First and Second Reconstructions, Kousser proceeds to give detailed accounts of the redistricting process in California, Tennessee, Georgia, North Carolina, and Texas. Due to extensive and well-documented research in contemporaneous sources such as political speeches, government documents, or newspaper articles, Kousser is able to offer considerable evidence that, at various points in history, state and local officials in these five jurisdictions drew municipal, state legislative, and state congressional districts with the explicit intention of keeping white politicians in power and preventing Black or Hispanic candidates from being elected. As one might expect, Kousser praises the series of court cases that outlawed the most egregious racial gerrymandering practices and gave minorities a better chance for representation.

It is in North Carolina, Kousser says, that the law began to go awry. He discusses the state's record of racial disenfranchisement in the past, and accuses the Supreme Court of failing to meet its obligation to preserve minority rights in the present. In Shaw $v$. Reno in 1993, the Court ruled that five white plaintiffs who objected to the legislature's redistricting plan had a valid claim under the Constitution's Equal Protection Clause, on the grounds that the plan was an unjustified attempt to segregate voters based on race. Kousser says that he "do[es] not find evil motives everywhere," but he certainly believes he has found them on the Supreme Court. He condemns Chief Justice William Rehnquist's racial views and accuses Justice Sandra Day O'Connor of political partisanship. Kousser describes Shaw $v$. Reno as the beginning of a radical trend that threatens to reverse the course of the Second Reconstruction.

Many patrons may be intimidated by this book, as it is lengthy, full of references to court cases and statutes, and peppered with political and legal jargon. Others may be repulsed by the author's palpable disdain for many of those who disagree with him; he often pauses to grind an ideological axe against the works of rivals such as Professor Abigail Thernstrom. Despite these problems, Colorblind Injustice offers a thorough and passionate discussion of minority voting rights, and due to its coverage of events in North Carolina, it will probably be of interest to teachers and students of law, history, and politics throughout the state.

Recommended for academic libraries. 


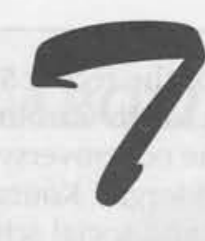

he historic architecture of North Carolina extends across a broad range of decorative styles and construction types, reaches through many generations of development, and forms a rich cultural panorama through the alliance of people and places. A Guide to the Historic Architecture of Western North Carolina is the second of a trilogy of regional field guides: Eastern, Western and Piedmont, that presents a concise yet highly informative introductory essay about an almost unknown area of the state. Topics include the picturesque and often rugged terrain of foothills and mountains, human habitation over millennia, the growth of communities and industries, and a special section on the visionary planning and accomplishment of the Blue Ridge Parkway, rightly regarded as "one of America's greatest public works achievements and most popular scenic attractions." Throughout the essay, illustrations depict representative scenes and structures that add depth to the written word.

The guide is especially useful for the abundant reference

Catherine W. Bishir, Michael T. Southern, and Jennifer F. Martin.

\section{A Guide to the Historic Architecture of Western North Carolina.}

Chapel Hill: University of North Carolina Press, 1999. 483 pp. $\$ 34.95$ cloth, ISBN 0-8078-2465-8; $\$ 19.95$ paper, ISBN 0-8078-4767-4. maps placed at the front of the book. Each county has a fullpage map showing each historic site clearly marked by a numerical code. Nearby towns, rivers, highways, and rural routes serve as geographic references. Subsequent chapters trace diverging paths through eight foothill counties: Surry, Wilkes, Alexander, Caldwell, Burke, McDowell, Rutherford, and Polk; and eighteen mountain counties: Alleghany, Ashe, Watauga, Avery, Mitchell, Yancey, Madison, Buncombe, Henderson, Transylvania, Haywood, Jackson, Macon, Swain, Graham, Graham, Clay, and Cherokee. The result is an aweinspiring compendium of some 1,200 historic sites, touching on log dwellings and outbuildings, rural meeting houses, farmsteads, community and government buildings, bridges, schools, churches, mountain retreats, cities, and villages. The entire effort of research, writing, and illustration is as expansive as the mountains themselves; the reader and adventurer are led through a vast but intimate land where culture and geography are closely allied; and the study weaves through the lives of numerous authors, poets, painters, and politicians. The photographs accompanying the entries for dramatically sited structures set in spacious surroundings are especially provocative. Biltmore, where it was said "the mountains are in scale with the house," is just one of a wealth of architectural treasures - from cabins to castles - that abound in the region. The book concludes with one of the best architectural glossaries yet produced, a valuable bibliography,sources of information, and photographic credits.

The authors, Catherine W. Bishir, Michael T. Southern, and Jennifer F. Martin, are associates in the North Carolina State Historic Preservation Office in Raleigh. All are obviously enamored of the western region of the state, and the latter two were formerly affiliated with the Western Office of Archives and History in Asheville. The guide is part of the Richard Hampton Jenrette Series in Architecture and the Decorative Arts.

- Edward F. Turberg

Architectural Historian, Wilmington, NC

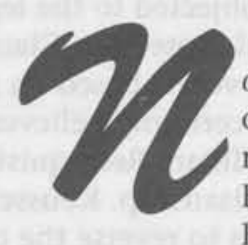

o Hiding Place is an anthology of stories, poems, articles, and excerpts from the works of writers associated with the city of Charlotte, North Carolina, and, in the words of novelist Robert Inman, is a tribute to them and "to the spirit which moves their work." Edited by Inman and local writers Frye Gaillard and Amy Rogers, and funded by the Public Library of Charlotte and Mecklenburg County, the book is a remarkable example of the contributions a public library can make to the cultural life of a community. It continues PLCMC's tradition of building Charlotte's reputation

Frye Gaillard, Amy Rogers, and Robert Inman, editors.

\section{No Hiding Place: Uncovering the Legacy of Charlotte-Area Writers.}

Asheboro: Down Home Press, in association with the

Public Library of Charlotte and Mecklenburg County, 1999. 274 pp. Paper, \$16.95. ISBN 1-878986-69-3. as an important literary center, as seen in their 1988 anthology, The Imaginative Spirit: The Literary Heritage of Charlotte and Mecklenburg County, and literary festival Novello, a major citywide event since the early 1990 s.

The collection begins with selections by seven "Legends" from days gone by, including Erskine Caldwell, Carson McCullers, W. J. Cash, and Charles Kuralt. Harry Golden's satirical essay "The Vertical Negro Plan" is a standout in this section, suggesting that since White southerners had no problem standing up with Blacks in banks and department, the solution to the school segregation 
problem was simply to remove all the seats. He notes that the students "are not learning to read sitting down anyway; maybe standing up will help."

The fiction section includes stories and novel excerpts from 14 writers, among them Dori Sanders, a close-by South Carolina writer who writes in Charlotte. Robin Hemley's "A Printer's Tale" will be a treat to anyone who ever suffered through an amateur poetry reading. Banker Joe Martin's "Sister Holy Ghost and the Fourth of July," a slow-building, ultimately stunning indictment of segregation, is the story from which the title of the collection is taken. Max Childers's "What Comes Next" examines the lengths to which hard times will drive a Charlotte plumber. Readers will get a taste of forthcoming novels by Ashley Warlick and Fred Leebron.

The poetry section presents 14 accessible entries, none, by Robin Hemley's standards, offensive. Joseph Bathanti's "If I Returned to Rancor" carries out the theme of southern race relations which is so prominent in the collection: "This time the people would be friendly, / inviting my wife and me / to their churches ... Disputes would be settled through discourse, / and the town's name changed to Reconciliation. / We'd stay forever." Two entries reflect Charlotte's new immigrant populations: "My Turn" by Tanure Ojaide, a native of Nigeria, and "El Niño en la Hamaca," a poem in Spanish by Venezuelan-born Irania Macías Patterson. (For Patterson's report on library outreach to Charlotte's Hispanic community, see North Carolina Libraries, Winter 1998.)

Thirteen nonfiction pieces conclude the anthology. Especially memorable are Dot Jackson's "The Merger: A Ghost Tale or Maybe Not" and Doug Robarchek's "All You Want to Know About Women But Are Too Smart to Ask Us": "deep down, many of us guys are aware, in our rudimentary, slug-like way, that most women are smarter than us, more reasonable, more practical, tougher, and more flexible." Sam Fullwood III's "The Rage of the Black Middle Class" is enlightening; to balance it, Elizabeth Leland's account of the lifelong relationship between a prominent White family in Lincolnton and a mentally retarded Black man, "Joe Hill: 55 Years of Family Love," is heartwarming.

Each piece in this collection is introduced with a brief note explaining the connection of the author to Charlotte. Some of these are slight or of brief duration, most are substantial. Brief biographies of the authors and bibliographical credits conclude the volume. Fans of North Carolina writers will recognize many names and learn others to watch for, and even casual browsers will be impressed with the quality of this anthology. No Hiding Place's most important contribution may well be the introduction of many of Charlotte's journalists to readers who do not follow the Charlotte Observer. From W.J. Cash, Harry Golden, and Kays Gary to Doug Robarchek, Kathryn Schwille, and Dan Huntley, these deserve a wide audience. Recommended for school, public, and academic libraries.

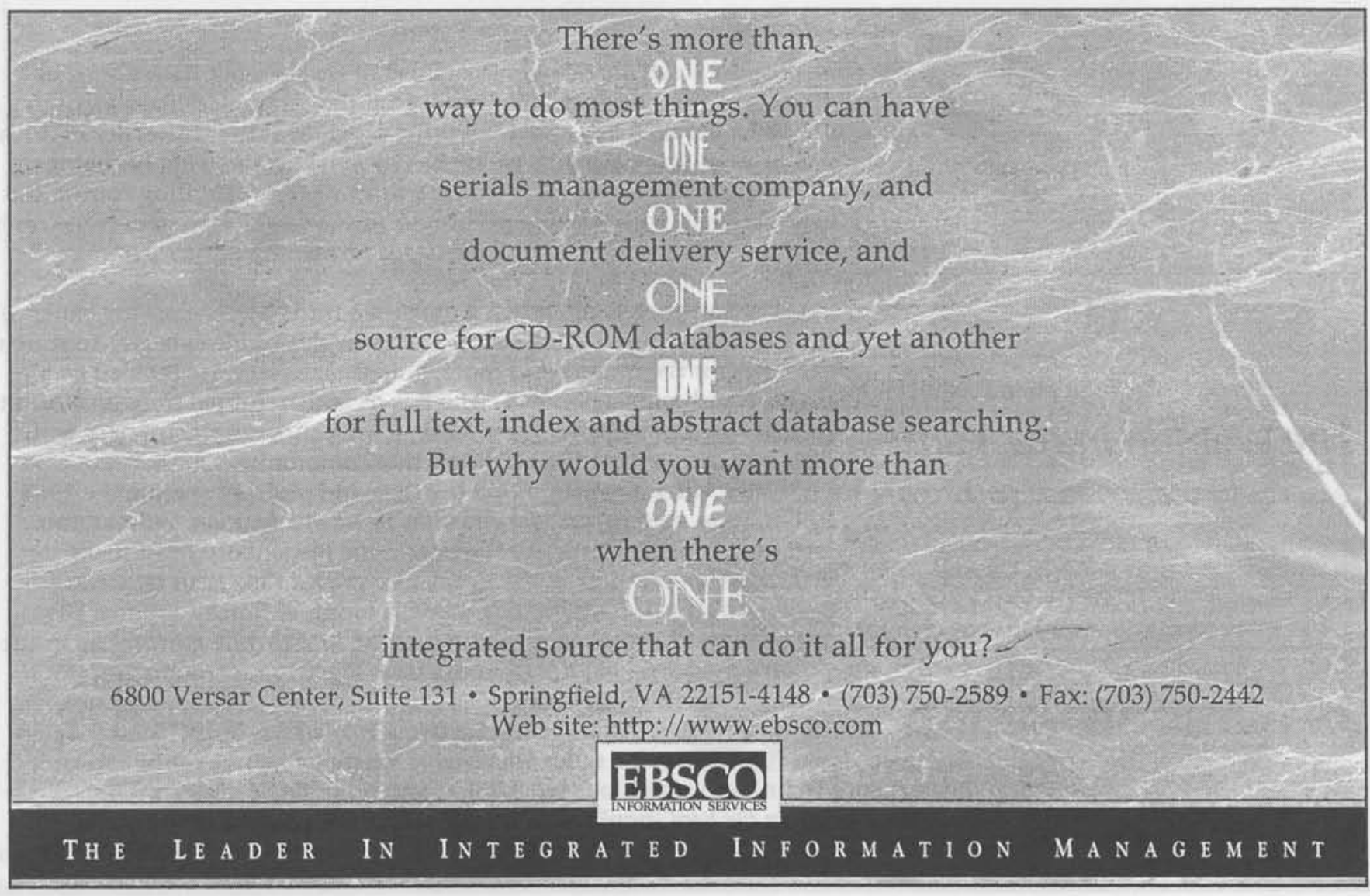




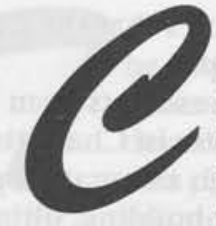

urly Dickerson made a World War II museum out of his pool house. It started out as a poster display in his driveway. Folks from the neighborhood saw his staggered line of easels, slowed down, stopped, and got out to take a look. It was his neighbors' positive reactions that led Curly to clean the exercise equipment, pool supplies, and other odds and ends from his 10 by 17 -foot backyard building. In their place, he put photographs, newspaper articles, maps, uniforms, and other relics. These items told the story of the depression-era kids who went to war in the 1940s.

Curly Dickerson's memoir is the product of the same sort of homespun selfreliance and initiative. In Citizen Soldiers, one of the best books written abut World War II, Stephen Ambrose notes that the war's defining characteristic

Douglas F. Dickerson, as told to Bruce Washburn.

\section{Doing My Duty: The Life Story of Douglas "Curly" Dickerson.}

Burnsville, NC: Celo Valley Books, second edition 1998. xii, 139 pp. Paper, \$14.00. ISBN 0-923687-50-5. was the ability of regular G.I.s to adapt, think for themselves, and carry out their missions with little direct supervision. If his book is any indication, Dickerson has maintained these qualities for more than fifty years.

It is easy to imagine Curly standing in his converted pool house telling a group of local Girl Scouts how, as a paratrooper with the 82nd Airborne, he jumped behind enemy lines and landed square on the back of a cow. When visiting veterans and their wives rehashed their "shipping out" romances, Curly must have laughed about how he married his beloved Edna Lee after having seen her only one time on a bus, followed by a courtship of letters. And when the old soldiers' talk grew solemn and memories of lost friends crowded the chlorinefilled air, Curly could count for them the twenty-some men lost from his special 30man unit. Dickerson's book is full of such stories, written as if he were standing in his Greensboro backyard reminiscing for friends and visitors. With sentences like, "I learned to dance from a boy named Joe Birddy" to "It was during this stalemate that I lost my friend Jake, who was our only remaining gunner," this is the kind of book everyone wishes his grandfather had written for him.

- Kevin Cherry

Rowan Public Library

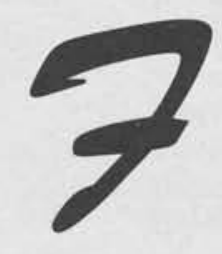

irst-time novelist Stephen D. Miller is a native of Durham but hasn't lived in North Carolina since he left to attend college at the Virginia Military Institute. After college he enrolled in a creative writing program at the University of British Columbia in Vancouver, Canada, where he has remained, making his living mostly as an actor. His award for winning a three-day novel writing contest was a Toronto book agent, who encouraged him to write a murder mystery based on his experience growing up in the South. He chose as his setting the port city of Wilmington during the tumultuous year of 1954 .

The suspense begins when a prostitute turns up dead on the banks of the Cape Fear River. Acting sheriff Q.P. (Kewpie) Waldeau begins to search

Stephen E. Miller.

\section{The Woman in the Yard.}

New York: Picador USA, 1999. 294 pp. \$23.00. ISBN 0-312-19962-7. earnestly for the murderer as more killings take place. He is aided by a native Jewish public librarian, who has recently returned from up North to be with her dying father. Together they work through the mystery with little help from either the black or white community.

Miller successfully captured the time and place by reading the 1954 Wilmington newspapers. Brown vs. the Board of Education, Wilmington localities, politics, Hurricane Hazel, and the Bladenboro Beast make believable appearances in the novel, and the Ku Klux Klan rally was fashioned after one which took place in Monroe, North Carolina. His characters are a composite of the many Southerners he knew while growing up in the 1950 s, rather than actual personalities from the area. The two exceptions are a local congressman and the editor of the newspaper.

The author is no stranger to suspense. He frequently shows up as "Special Agent Andy McClaren" on the Fox-TV series Millennium, where he helps ex-profiler Frank Black (Lance Henriksen) search out serial killers and other fin de siecle crazies.

The Woman in the Yard should be a favorite with public library mystery readers. - Beverly Tetterton New Hanover County Public Library 


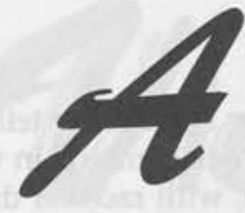

nyone who wants to understand North Carolina politics must start with Paul Luebke's Tar Heel

Politics 2000. This well-documented study, a revision and update of his Tar Heel Politics: Myths and Realities (1990), analyses state politics over the last 50 years and sets the stage for what is to come in the new millennium. Luebke writes from a unique perspective; he is both an academic (a professor of political sociology at the University of North Carolina-Greensboro) and a politician (a Democratic member of the North Carolina House since 1991), but this book is the work of the scholar. Although his political participation no doubt informs his analysis, his political views do not intrude.

More than a narrative of political events, this book is an insightful and detailed look at what happened and why. Luebke explains North Carolina politics by identifying and demonstrating the effects of the two conflicting ideologies, traditionalism and modernism, which have most influenced state politics and government in the last half of the century. Using the framework of these philosophies, he analyses the tremendous changes that have taken place in the

Paul Luebke. state- the shift from an agricultural to a manufacturing and now growing ser-

\section{Tar Heel Politics 2000.}

Chapel Hill: University of North Carolina Press, 1998. 273 pp. Cloth, \$34.95. ISBN 0-8078-2452-6. Paper, \$14.95. ISBN 0-8078-4756-9. vice economy, the rise of both the Republican Party and Black voters and office holders, and the increasing influences of urban areas and in-migration. One of the disturbing conclusions of his analysis is that both traditionalists (e. g., Helms, Brubaker, Jimmy Green) and modernists (e.g., Sanford, Holshouser, and the old Hunt) believe that what's good for business is good for everyone, the old trickle-down theory, which makes the welfare of the majority of middle- and lower-income citizens a lower priority.

The book is a textbook that will surely be required reading in North Carolina history and political science classes, but it is also full of fascinating political stories: how Jesse Helms won five Senate elections and what Hunt and Gantt could have done to win; how an "unholy alliance" of populists (a third ideology that has had relatively little influence in recent North Carolina politics) and Republican traditionalists reduced the food tax; and how Jim Hunt has evolved from a modernizer into a blend of traditionalist-modernizer. One looks forward to the next edition's stories of John Edwards's election to the Senate and the failed attempt to elect Dan Blue House Speaker.

Every North Carolina library should own this book, and every policy maker, potential candidate, and concerned citizen should read it.

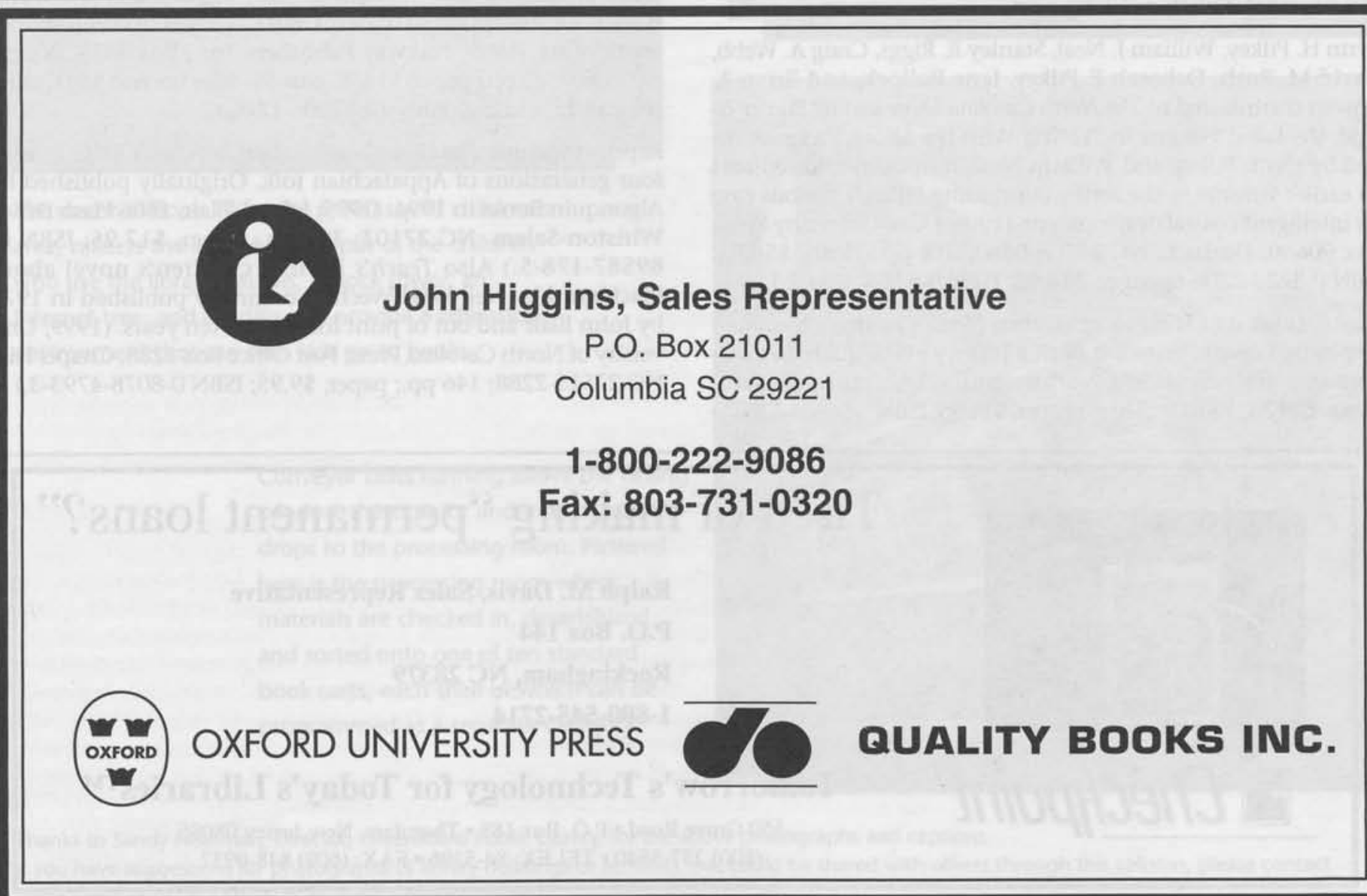




\section{Other Publications of Interest ...}

Serious literature collections, students of the novel, and avid fans of the state's most eminent novelist will want Learning a Trade: A Craftsman's Notebooks, 1955-1997. Reynolds Price himself compiled the journal of his writing life with a bare minimum of editing, judging that "an unvarnished attempt to demonstrate one man's effort to learn his craft should not be subject to omissions in the interest of sheer readability." (1998; Duke University Press, Box 90660, Durham, NC 27708-0660; xx, 603 pp.; cloth, \$34.95; ISBN 0-8223-2112-2.)

New Ground is a collection of stories and poems about relationships between men and women by Nancy Dillingham, a native of Dillingham, North Carolina, and a resident of Asheville. In his foreword Fred Chappell, the state's Poet Laureate, calls it an "odd but utterly genuine book, one that tastes of experience in every line." (1998; WorldComm, 65 Macedonia Road, Alexander, NC 28701; 159 pp.; paper, \$9.95; ISBN 1-56664-134-9.)

Waking Up in a Cornfield is a collection of columns by Chris Cox, published in the Alleghany News, Boone's Watauga Democrat, Waynesville's Enterprise-Mountaineer, and the Asheville CitizenTimes, among other newspapers. Having omitted political commentary and movie reviews, what he offers here is personal narrative, reflecting his editors' generosity in letting him "write most anything I've wanted." (1999; Parkway Publishers, Inc., Box 3678, Boone, NC 28607; 154 pp.; paper, \$14.95; ISBN 1-887905-13-8.

In Blue Ridge 2020: An Owner's Manual, author Steve Nash draws on scientific research in a variety of disciplines to introduce some of the most hotly disputed environmental issues facing the area that includes the largest concentration of public lands east of the Mississippi. (1999: The University of North Carolina Press, Post Office Box 2288, Chapel Hill, NC 27515-2288; 211 pp.; paper, \$19.95; ISBN 0-8078-4759-3.)

Orrin H. Pilkey, William J. Neal, Stanley R. Riggs, Craig A. Webb, David M. Bush, Deborah F. Pilkey, Jane Bullock, and Brian A. Cowan contributed to The North Carolina Shore and Its Barrier Island, the latest volume in "Living With the Shore," a series edited by Orrin Pilkey and William Neal. It updates and replaces an earlier volume in the series, continuing Pilkey's famous case for intelligent coastal development. (1998; Duke University Press, Box 90660, Durham, NC 27708-0660; 318 pp.; cloth, \$54.95; ISBN 0-8223-2208-0; paper, \$18.95; ISBN 0-8223-2224-2.)

Mines Miners and Minerals of Western North Carolina's Mountain Empire by Lowell Presnell is both a history and a guide to a fascinating subject. (1999: Worldcomm, 65 Macedonia Road, Alexander, NC 28701; 256 pp.; paper, \$14.95; ISBN 1-56664-135-7.)
Great Adventures in North Carolina by Lynn Setzer tells you how and where to do everything from rock climbing in the mountains to hang gliding at the beach, with race car driving and enjoying wildflowers in between. (1999; Menasha Ridge Press, 700 South 28th Street, Suite 206, Birmingham, AL 35233; 209 pp.; paper, \$15.95; ISBN 0-89732-262-2.)

Historic Asheville, by Bob Terrell, covers 200 years of the city's history, bringing it from "hard-crusted frontier" to modern city. Includes black and white photographs, but has no index. (1997; WorldComm, 65 Macedonia Road, Alexander, NC 28701; 256 pp.; paper, \$14.95; ISBN 1-56664-124-1.)

"A Rising Star of Promise": The Civil War Odyssey of David Jackson Logan, is the story of a South Carolinian who served in Wilmington and Kinston, North Carolina, among many other posts. Edited by SamueI N. Thomas, Jr., and Jason H. Silverman. (1998; Savas Publishing Company, 1475 S. Bascom Avenue, Suite 204, Campbell, California 95008; 255 pp; cloth, \$32.95; ISBN 1-882810-29-5.)

Letters to the Home Circle: The North Carolina Service of Pvt. Henry A. Clapp, an articulate young soldier from Massachusetts, is edited by John R. Barden and is part of a popular series. It is illustrated with maps, sketches, and photographs, and includes index and bibliography. (1998, Historical Publications Section, Division of Archives and History, 109 East Jones Street, Raleigh, NC 27601-2807, 252, paper, \$28.00, ISBN 0-86526-270-5, )

Sal Kapunan, a Philippine-born philosopher who lives in Boone, North Carolina, and Cape Coral, Florida, has written My Taoist Vision of Art in response to the interest generated by the dozens of large and fanciful handmade sculptures that adorn his yards. Color photographs by William A. Bake, David S. Hamilton, and the author will appeal to students and collectors of visionary and outsider art. (1999; Parkway Publishers, Inc., Box 3678, Boone, NC 28607; 45 pp.; paper, $\$ 14.95$ plus $6 \%$ sales tax and $\$ 3.00$ shipping and handling; ISBN 1-887905-12-X.)

Reprints include The Hinterlands, Robert Morgan's first novel of four generations of Appalachian folk. Originally published by Algonquin Books in 1994. (1999; John F. Blair, 1406 Plaza Drive, Winston-Salem, NC 27103; 335 pp.; paper, \$17.95; ISBN 089587-178-5.) Also Teach's Light, a children's novel about Blackbeard by Nell Wise Wechter originally published in 1974 by John Blair and out of print for the last ten years. (1999; University of North Carolina Press, Post Office Box 2288, Chapel Hill, NC 27515-2288; 146 pp.; paper, \$9.95; ISBN 0-8078-4793-3.)

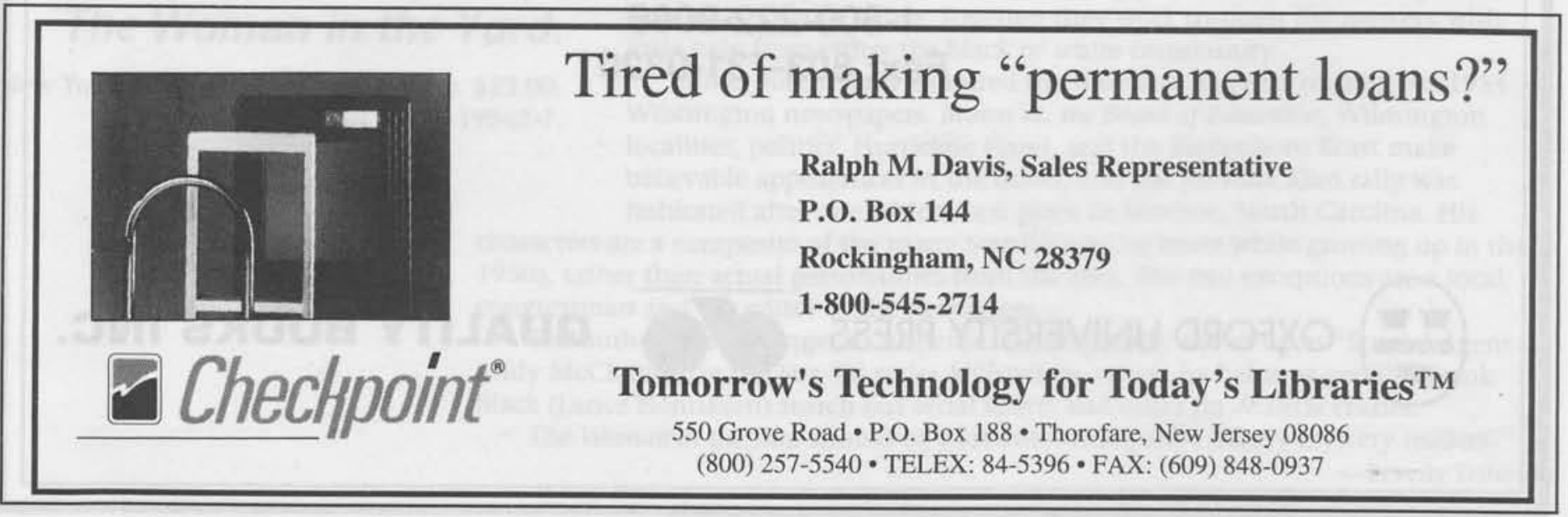




\section{in View of ...}

The 98,550 sq. ft. new

Greensboro Central Library

opened October 21, 1998. With two floors,

the facility provides $184 \%$ more space

for the public than the previous location.
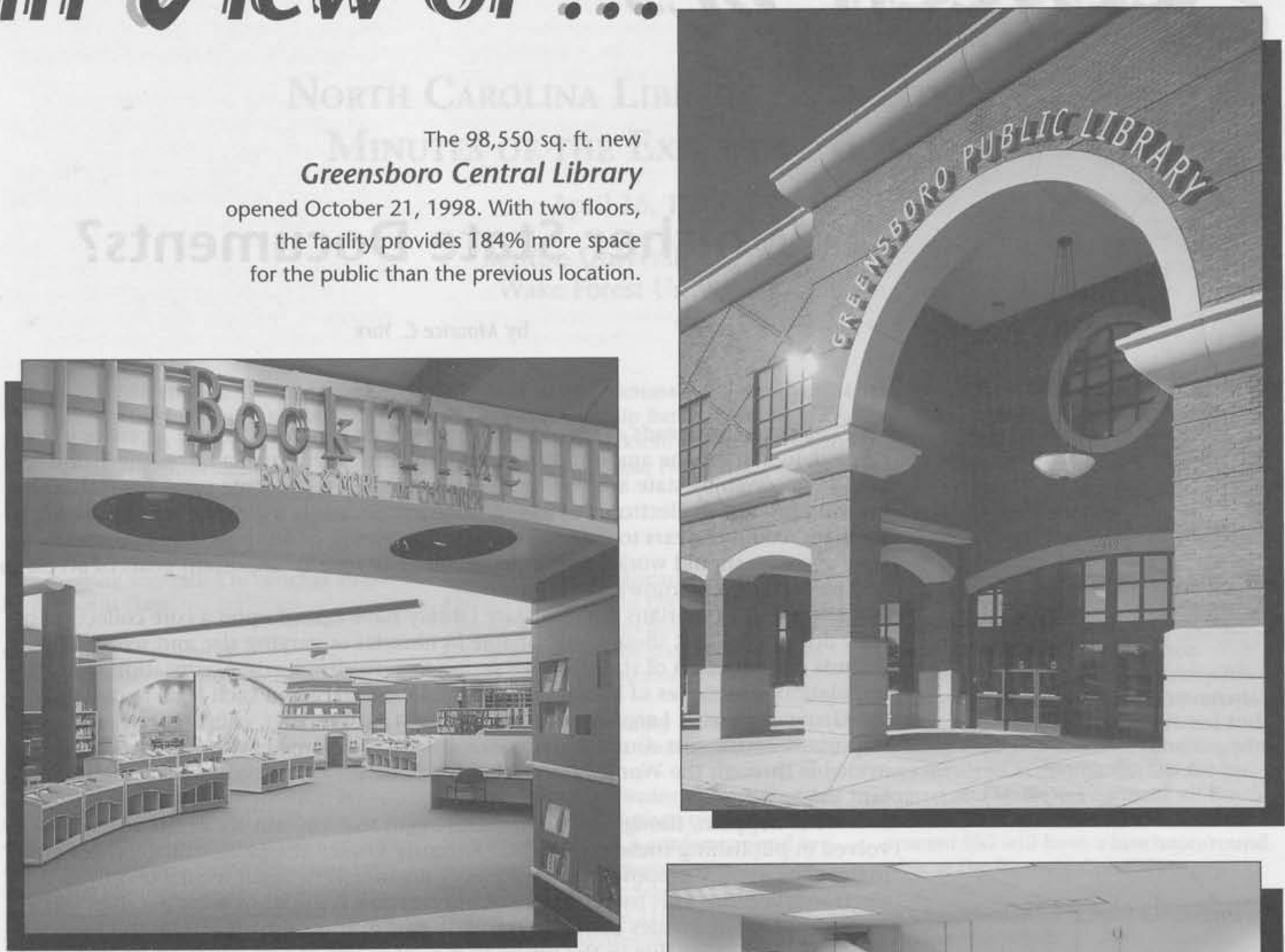

The decor of Book TiMe, the 6,000 sq. ft. children's area, reflects the imaginative input of the children who use the library. Murals, a clock tower, an Internet tree, and a video wall provide a whimsical environment that can turn kids on to books.

Conveyor belts running above the ceiling connect the exterior and interior book drops to the processing room. Pictured here is the processing room where materials are checked in, desensitized, and sorted onto one of ten standard book carts, each shelf of which can be programmed as a separate category.

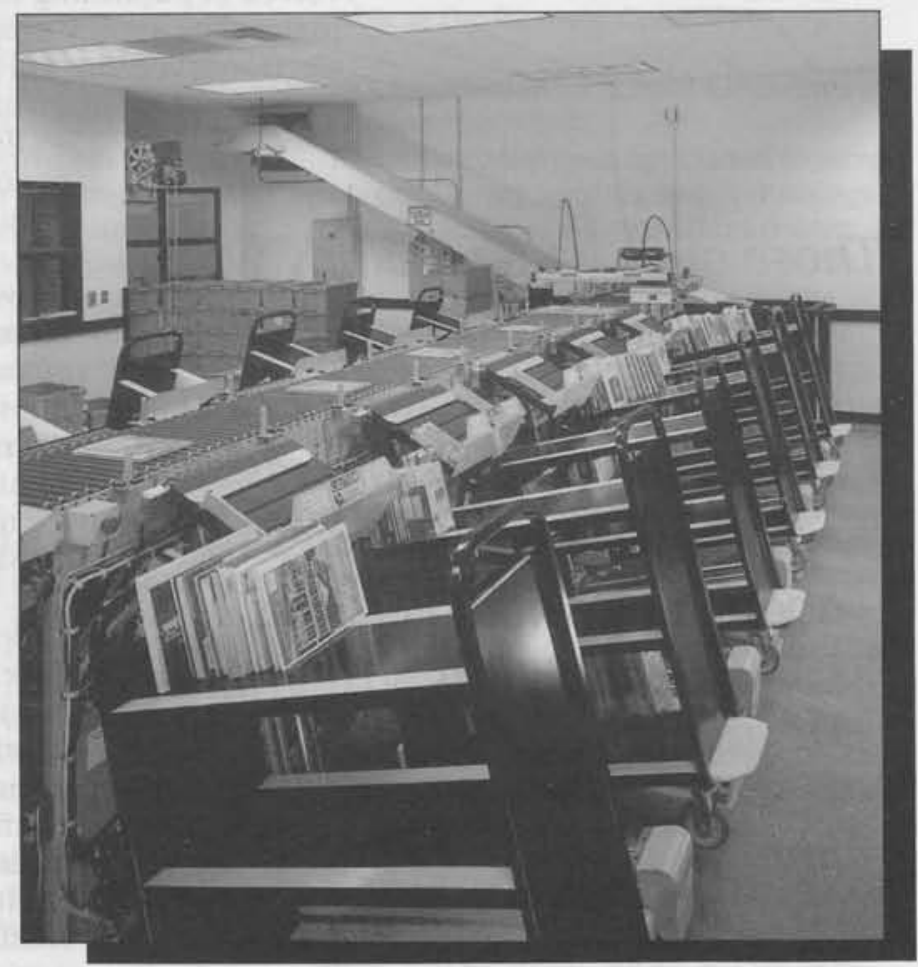

Thanks to Sandy Neerman, Director, Greensboro Public Library, for the above photographs and captions.

If you have suggestions for photographs of library buildings or activities that could be shared with others through this column, please contact Joline Ezzell at (919) 660-5925 or joline.ezzell@duke.edu 


\title{
Whither State Documents?
}

\author{
by Maurice C. York
}

$\mathbf{L}$

et's keep our heads as we plan for our glorious electronic future. I constantly am delighted by the amount of information being made available on the World Wide Web by state agencies in North Carolina. At the same time, I fear that the growing interest in electronic access to information, while a great benefit at the moment, could in years to come jeopardize knowledge of our past. Librarians and state agencies should work together to balance the equally important goals of access to and preservation of knowledge of our state.

Documents librarians and the State Library have agreed upon a core collection of state documents that should be available in libraries of varying size and scope. These include compilations of statistics pertaining to agriculture, crime, education, and population; directories of businesses and public officials; and such legal materials as the General Statutes. Large libraries often collect session laws, court reports, and other important documents. Current or very recent years of some of these sources are now available through the World Wide Web. This trend greatly improves access to important information.

What happens, though, when agencies begin to complain about the costs involved in publishing these documents? Recently I heard the publications officer of a major state agency propose that a very basic document be made available only in an electronic version. This useful source of information is found in most libraries; our collection contains issues dating to the early part of this century. Would the agency be willing in the future to mount scores of past issues on its Web site? I doubt it. If such an attitude prevails, then we might be in danger of

Those of us who regularly work with state documents and understand their current and historical value should resist efforts by state agencies to abandon printed versions of key publications. losing ready access to knowledge of our past.

Librarians should think hard about why libraries exist before allowing this to happen. In addition to providing access to current information, libraries traditionally have sought to preserve a record of the past. People who actually visit libraries often discover treasures of which they had no knowledge, but that are of great value to them. Librarians often play an important role in this process. The architecture or decor of some libraries inspires users to want to learn. Certainly all libraries foster a sense of community that would be hard to duplicate on the Web.

Those of us who regularly work with state documents and understand their current and historical value should resist efforts by state agencies to abandon printed versions of key publications. We must reach a consensus about titles that should continue to appear in print and partner with state agencies to insure that this goal is accomplished, much as librarians did years ago when the North Carolina State Depository System was established by the General Assembly. Which documents are easier to use in printed rather than electronic form? Which ones must always be available, regardless of seemingly capricious changes in computer hardware and software? These and other questions must be thoughtfully considered.

Let the World Wide Web, through indexes, databases, and other means continue to improve lives by providing faster access to information we all need. Let libraries, while fostering this trend, continue to serve as stewards of our cultural heritage. 


\title{
North Carolina Library Association Minutes of THE Executive BoARD
}

\author{
April 16, 1999 \\ Benton University Center \\ Wake Forest University
}

\begin{abstract}
Attending: Beverley Gass, Al Jones, Diane Kester, Vanessa Work-Ramseur, Martha Davis, Teresa McManus, Bobby Wynn, Mary Horton, Rhoda Channing, Phillip Banks, Carolyn Price, Kevin Cherry, Patrick Valentine, Ross Holt, George Taylor, Dave Fergusson, Gwen Jackson, Catherine Wilkinson, Frances Lampley, Ann Burlingame, Tracy Babiazs, Susan Smith, Eleanor Cook, Peggy Quinn, Karen Gavigan, Melinda Ratchford, Liz Jackson, Maureen Costello
\end{abstract}

The meeting was called to order at 10:00 by President Gass.

\section{Corrections to minutes}

A motion to accept the minutes as written passed.

\section{President's Report}

Julie Hersberger, a faculty member in the School of Library and Information Science at UNCG, has agreed to chair a committee to consider the impact of charter schools and home schooling on the state's libraries. George Taylor of the Forsyth County Public Library has agreed to chair the committee to plan the 2000 NCLA Leadership Institute.

A reminder was given that committee chairs are not voting members of the Board.

Maureen Costello has spent considerable time collecting committee rosters. Committee chairs who have not supplied names of committee members are urged to do so as soon as possible. Maureen has also completed Guidelines for Workshop Planners.

\section{Treasurer's Report}

A budget report for the first quarter was distributed. Sections who wish individual reports may contact Diane Kester. Two special grants NCLA is administering in cooperation with the State Library are reflected on the budget report. NCLA receives a percentage of project profits. A motion to accept the report as written passed.

\section{Section/Round Table Reports} Children's Services Section

Confirmation on keynote speaker Johanna Hurwitz for the CSS breakfast meeting is being awaited. Programming, library services to Hispanic children, and a panel discussion of the successful State Library grant-funded program "Mother Goose and More" are part of the agenda for the NCLA conference.

\section{College and University Section}

Committee minutes are posted to the Web.

Community and Junior College Section At this time, CJCLS plans to sponsor two sessions at the NCLA conference and to co-sponsor a third session with the College and University Section. "Redesigning Libraries for the 21st Century" is scheduled for Wednesday, September 22, 1999. On Thursday, September 23, CJCLS will sponsor a program on "Intellectual Freedom Issues Surrounding Internet Use." Some consideration is being given to making this a panel discussion and including other presenters. The co-sponsored session will be entitled "Copyright and the Digital Age."

\section{Douments Section}

Final arrangements for the spring workshop "Technical and Medical Literature on the Web" are being made. The workshop will be held May 21 at the McKimmon Center in Raleigh. Additional information on registration is available at: <http:/www.metalab.unc.edu/ reference/docs/ncladocs/index.html>.

The Biennial Conference program will cover state, federal and international statistics in such areas as demographics, health, business and education. The program is scheduled for Wednesday, September 22 .

\section{Library and Management Section} The LAMS Board has been communicating via email. The brochure for the
Mentoring program was sent to Maureen Costello for printing and distribution. Sessions have been planned for participants at the Biennial Conference.

A second Special Interest Group has been proposed for circulation librarians. Robert James of UNCG is interested and is being assisted by Debbie Lambert, who was involved in getting the SIG for Personnel and Staff Development off the ground. The Personnel and Staff Development SIG will have a luncheon/round table at the Biennial Conference.

\section{NC Association of School Librarians} Section

Karen Perry has been appointed to serve on the Library Services and Technology Act Committee, a 3 year commitment.

Current membership stands at 389 .

Laura Williams is working on the Web page. Links will be added for membership and other conferences.

NC Book Award voting took place in March.

Karen Gavigan represented NCASL at the Affiliate Assembly. There is new leadership with new officers. Nineteen states were represented.

A five-day conference sponsored by ALA will be held in Las Vegas to explain the changes in Information Power. Further, ALA will offer a one day training session at their conference this summer, which Karen Gavigan will attend. Frances Bradburn will present a conference on Information Power next fall at NCETC.

Summer workshops are being planned in Greenville, Rowan Community College, and Asheville. Topics will include new materials, flexible scheduling, NC Book Award and Battle of the Books.

It was decided that concerns about financial arrangements with NCLA were 
to be brought to the NCLA Executive Board for discussion.

\section{NC Library Paraprofessional Round} Table

Sue Mellott is the new liaison with

Children's Services Section.

NCLPA will co-sponsor with PLS and CSS their sessions at the Biennial Conference. Additionally, a luncheon/business meeting and a workshop on reference for children will be held.

NC Public Library Trustee Association There was no report. However, discussion was held about the role of trustees, including the idea of joining the trustees with the Friends group.

\section{New Members Round Table}

Conference plans are being made. Plans to hold a grant writing/fundraising workshop this summer are being firmed up and brochures are being prepared.

A newsletter is due out in May.

The mentoring committee has completed and sent brochures about this program.

The letter to new members now requests them to contact Tracy regarding involvement in NCLA. Several contacts have been made. Also, the Web page address is on the welcome letter.

\section{Public Library Section}

There was no report.

\section{Reference \& Adult Services Section}

Plans for the Biennial Conference are to have Maggie Jackson, Associated Press agent in New York City, to talk about "Our Patrons in the New Millennium" during the September 23rd luncheon. Maggie was chosen because of an article she wrote concerning GenXers that appeared in the Winston-Salem Journal. On Wednesday, September 22nd, RASS will co-sponsor with RTSS a workshop featuring John Webb on "Electronic Resources."

Philip Banks is the representative to the Continuing Education Committee.

Nominations are being determined for the 1999-2001 biennium.

\section{Resources \& Technical Services}

The main focus of current activities is planning for the NCLA biennial conference. The major program is being $\mathrm{Co}$ sponsored with RASS. RTSS is sponsoring four table talks that feature topics being addressed in the major program. Librarians who have experience dealing with the topics are facilitating each session.

The awards committee is charged with determining those to be presented the student award, the significant contributions award, and the award for the best article on resources and technical services in North Carolina Libraries. Awards will be presented at the biennial conference. Nominations are being sought for the first two awards on the RTSS Web page <http://www.unc.edu/ ldsmith/rtss/rtsshomepage.htm>.

The board has been involved in the planning of the fall issue of North Carolina Libraries, being edited by Page Life, the RTSS board member on the NC Libraries editorial board. The issue entitled "Life and Limb" will feature articles on health and safety issues in the library setting.

The membership committee is initiating a RTSS membership drive and surveying the RTSS members to update the directory. The committee in conjunction with the board will be developing publicity materials for conference programs.

Round Table for Ethnic Minority Concerns

There was no report.

Round Table on Special Collections A session at the Biennial Conference entitled "Documenting the African-American Experience: African-American Archives in North Carolina" will be sponsored.

The South Carolina State Library has picked up a local history collection program that had been presented two years ago. Also, a previous workshop on oral history has been requested by the state again.

\section{Round Table on the Status of Women} in Librarianship

There was no report.

Technology \& Trends Round Table Spring workshops will be held at GTCC on April 22, 1999. Speakers will discuss computer care and future trends.

William Terry has been formally contacted to speak at the Biennial Conference.

\section{Committee Reports}

Administrative Office and Personnel Advisory Committee

There was no report.

\section{Archives Committee}

There was no report.

\section{Conference Committee}

Plans for the Biennial Conference are proceeding according to the planning time line.

A Web page for the conference has been developed by Bao-Chu Chang and is available at <http://www4.ncsu.edu/ bcchang/ncla.html $>$. Copies of minutes of the Conference Committee and the latest information about exhibits, rooms, registration, program, placement/recruitment and local arrangements have been posted for perusal.

Program planners from the various sections, round tables and special groups have been in contact with Phil Barton,
Program Chair. Preliminary and interim plans have been received and forwarded to Barbara Anderson, Local Arranements Chair, for assignment of meeting rooms. Program planners are reminded to submit photographs for the conference program booklet.

The opening session speaker on Wednesday, September 22 will be Sally Helgesen, futurist. Maureen Sullivan, ACRL President and consultant with the State Library on interlibrary cooperation in North Carolina, will present the Ogilvie Lecture on Thursday afternoon, September 23. The North Carolina Storytellers will provide entertainment for the September 24 Friday morning breakfast.

Information has been sent to over 500 potential exhibitors. About one-third of the 120-exhibit booths have been rented.

Registration forms and supporting materials will be mailed in the summer well in advance of conference reservation deadlines.

Gerald Holmes, Recruitment and Placement Chair, is planning a program on recruitment of minorities to the profession as well as scholarship opportunities for minority candidates through the Spectrum Initiative of ALA.

$\mathrm{Al}$ Jones, Conference Chair, will be attending an ALA preconference program in New Orleans on recruitment and retention of members for state organizations.

\section{Constitution, Codes and Handbook Committee}

The Executive Board received handbook updates. Revisions will also go up on the Web. Chairs not present will receive updates by mail from Maureen.

\section{Continuing Education Committee} Some changes in the concepts initially presented were noted. Most specifically, the CE Committee will take a proactive role in education. Feedback from previous workshops can provide a needs assessment for further education. NCLA must make the best use of our resources including shared resources and services, but when there is a significant demand for information, various workshops would be most effective. State libraries, university libraries and technologies available should provide support in the continuing education endeavor.

A calendar page on the web site has offerings of the association. Discussion was held on whether this could be expanded to include new opportunities.

\section{Development Committee}

The Development Committee has negotiated with the NCCF for a contract that more clearly protects the interests of NCLA. The committee is awaiting word from the NCCF about the acceptability of the modified contract.

A resolution was presented to the 
Board allowing NCCF to receive endowment start-up funds from NCLA. The resolution was passed.

The Development Committee chair will meet with Anne Steele on April 20 to learn about marketing and publicity that the NCCF can provide for our endowment.

Future meetings will address fundraising efforts for the endowment.

The Development Committee chair moved that the Executive Board send a by-laws amendment to the membership at the Biennial Conference that will make the Development Committee a standing committee. This will ensure the growth of the endowment from biennium to biennium. The motion passed.

\section{Finance Committee}

The Finance Committee brought a recommendation to the Board that NCLA implement the use of credit cards to collect membership dues. Payment of dues by credit card on the Web requires use of secure server and some other issues and that was not recommended. It was decided that $\$ 4.00$ be returned from membership to sections for every member whether their membership has been paid for by credit card or not, but that all sections will share in the expenses of the credit card.

$4.06 \%$ of each credit card transaction is returned to the credit card vendor. Inquiries have been made about using credit cards to pay for conference registration. Computer software that costs $\$ 60.00$ can help the association keep those records accurately. For the one year that NCLA studies this concept, the organization will pay the credit card fees. The Finance Committee will deliver a report of the findings to the Board in one year. A motion was made to accept this recommendation and was passed. A reminder was made that membership forms will need to be revised to show this option.

Governmental Relations Committee This committee is organizing an ALA Legislative Day trip to Washington. Discussion was held regarding whether NCLA has considered the passage of a lottery in NC and the impact it might have on libraries in NC. A possible lobby to have NC LIVE included in the benefits of the lottery was suggested. Before the lottery is passed, decisions will have already been made regarding how proceeds would be spent. This committee has been asked to watch the legislative committees that would be charged with determining expenditures from the results of the lottery.

\section{Intellectual Freedom Committee}

Activities of this committee were shared. Among those were maintaining contacts and information regarding Intellectual Freedom issues.

Titles causing problems in North
Carolina are Babysitter Three, Lights Out, Monster Soup \& Other Spooky Poems, Playboy magazine and We All Fall Down.

This committee is soliciting nominations for the NCLA/SIRS Intellectual Freedom Award, which recognizes biennially the contribution of an individual or group who has actively promoted intellectual freedom in North Carolina. Nominations should be sent with supporting documentation to Dr. Gene D. Lanier, IFC Chair, Dept. of Broadcasting, Librarianship \& Educational Technology, East Carolina University, Greenville, NC 27858-4353. They can be faxed to 252 328-4368 or e-mailed to <lanierg@mail.ecu.edu>. Nominations must be received by July 30, 1999.

\section{Leadership Institute}

The call has been sent to 1996 and 1998 participants to plan the next Institute. So far, 12 people have responded. In a May meeting, a timeline will be developed and discussion about the issues surrounding the next institute will begin. Major topics will include marketing, location, and facilitators. The committee will investigate some of the issues that were presented in the recommendation report from the 1998 Institute.

\section{Literacy Committee \\ There was no report.}

\section{Membership Committee}

Nominations for NCLA's Life, Honorary, and Distinguished Library Service Awards have been solicited via NCLA and NC LIVE listservs. Nominations are being for- warded to President Gass. Awards are presented at the Biennial Conference. This committee will report back on the status of awards at the next board meeting.

As per the membership plan, tabletop displays are being considered. The committee will also investigate and report at the next board meeting.

Membership renewal was questioned. The history has been to have membership renewed on the calendar year for bookkeeping purposes. However, computer technology has changed this issue. A motion was made and passed to send a request to the Constitution, Codes and Handbook Committee to bring a reworded by-law change to the July board meeting. Part of this motion was to create the wording for a possible mail vote.

The membership brochure is promised for the end of April.

Peggy Quinn attended the Career Fair at the UNCCH Library School on February 17,1999 . She spoke with about 25 students about the benefits of NCLA, many of whom were specifically interested in the mentoring program.

An updated membership plan priority list was presented to Board members as well as a list of members by section/ round table.

\section{Nominating Committee}

Candidates for the 1999-2001 biennium of NCLA are:

Vice-President/President Elect: Jordan Scepanski, TPHI

Secretary: Sue Cody, UNCW, Carrie

Nichols, Meredith

Director - East: Sherwin Rice, Bladen

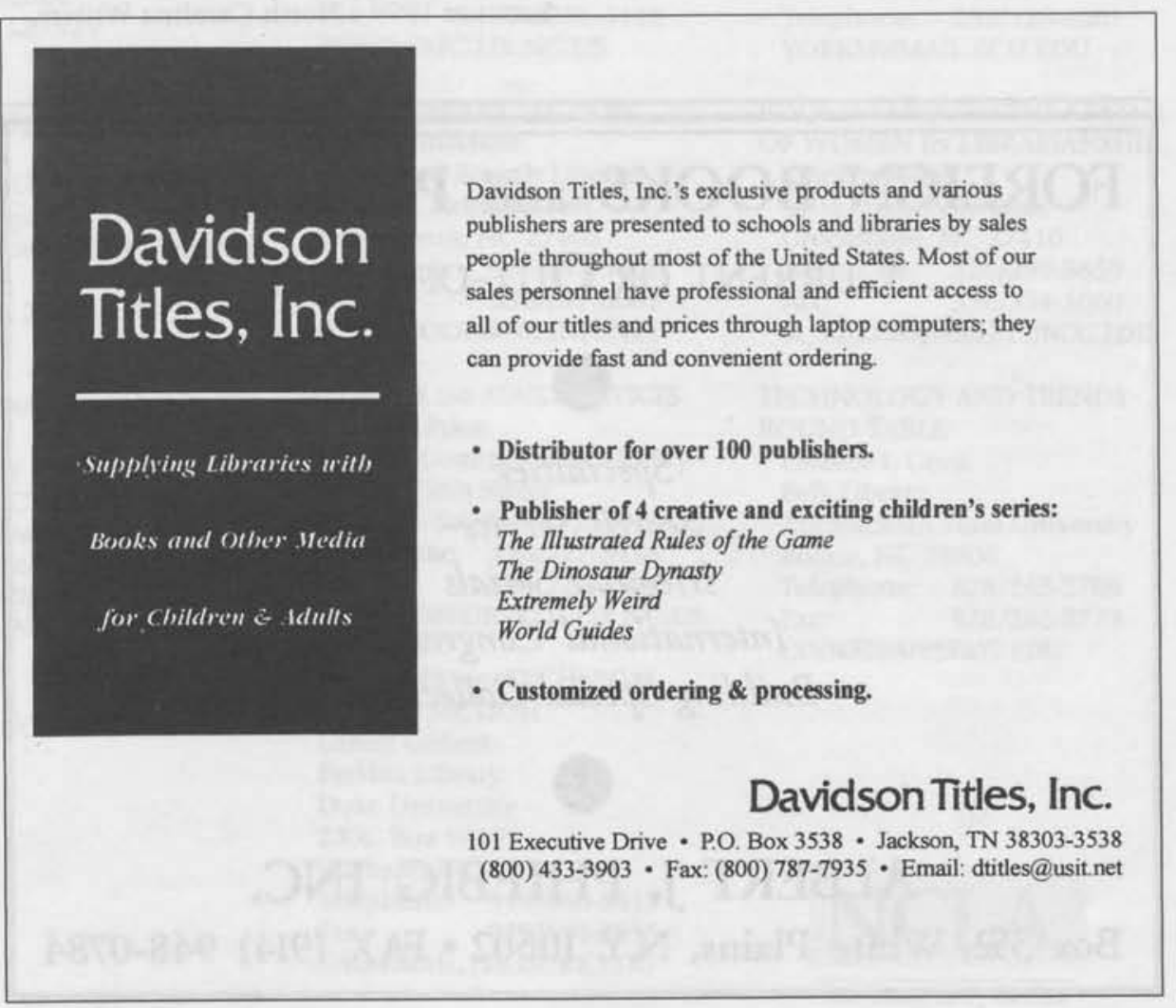


County Public Library, Patrick Valentine, Wilson County Public Library

Director-West: Phil Barton, Rowan

County Public Library, Rex Klett,

Mitchell Community College

SELA: Louvenia Summerfield, UNCC, John Via, Forsyth County Public Library

The Board was asked to consider existing NCLA leadership for an additional candidate for Vice-President/PresidentElect and submit names of possible candidates to Gwen Jackson.

Ballots will be mailed to the NCLA membership by May 1, 1999 with the deadline for returning them June 1 , 1999. The nominating Committee will count ballots the week of June 7 and notify the president of the results by June 11, 1999.

\section{Non-Conference Year Event Planning Committee}

Ideas brought to the Board focused on off year mini-conferences, an NCLA leisure/ social retreat, and a technology miniconference. Mini-conferences could be held in the east and west and follow major topics of interest to the membership. A leisure event would provide opportunities for recreation with fellow members along with possible literary program themes. A technology mini-conference could possibly be built into existing conferences as a pre-conference.

A request was made for Board members to take the information distributed back to their sections and give feedback to Dave Fergusson.

Publications and Marketing Committee There was no report.
Scholarship Committee

Committee minutes are posted to the Web.

\section{Special Projects}

Project Grants Committee

This committee has been charged to look at grant applications and determine if they are aligned with NCLA objectives. Sections, round tables, or committees of NCLA are eligible to apply for a grant. Single libraries or single members are not. The limit for a single grant is $\$ 1500$ and conferences, publications, Web projects and workshops are fundable through grants. Chairs must sign grant requests before being submitted.

Grant applications can be found on the NCLA Web site. Grant application deadlines are May 1, June 1, July 1, August 1, September 1, and December 1, 1999.

Home school ad-hoc committee Committee members were noted for this new task force. The committee will meet over the summer and formulate a report prior to the Biennial Conference. The committee is charged with considering library service to charter schools and determining the impact on public libraries.

\section{Other Reports \\ North Carolina Libraries}

The projected mailing date for the Spring issue of North Carolina Libraries, Outreach, is May 1 . The journal received its first royalty check from H.W. Wilson. Although it was only $\$ 19$, it is significant in that it is another revenue source, helpful since universities began cutting periodical budgets.

Upcoming issues:

Summer 1999 - North Carolina Writers,

\title{
FOREIGN BOOKS and PERIODICALS
}

\section{Current or OUt-OF-Print}

\author{
○ \\ Specialties: \\ Search Service \\ Irregular Serials \\ International Congresses \\ Building Special Collections
}

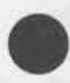

\section{ALBERT J. PHIEBIG INC.}

Box 352, White Plains, N.Y. 10602 • FAX (914) 948-0784

Alice Cotten, Guest Editor;

Fall 1999, Life and Limb, Page Life, Guest Editor;

Winter 1999 - Conference Issue;

Spring 2000 - Back to the Future:

Digitizing Resources, David Ferriero,

Guest Editor;

Summer 2000 - Preserving Local History, Plummer Alston Jones, Jr. and Thomas

Kevin B. Cherry, Guest Editors;

Fall 2000 - Research and Librarianship;

Winter 2000 - The Call of Story.

\section{ALA Councilor}

This report covered events of the 1999 ALA Midwinter Conference. President Symons' resolution on "Libraries: An American Value" was passed. NCLA had endorsed this resolution. Resolutions endorsing the Government Secrecy Reform Act of 1999 and supporting increased funding for the GPO were passed. A resolution directing ALA units to report on implementation of the 1990 policy on "Library Services to Poor People" was passed. A resolution asking that ALA withdraw its support of National TV Turn-off Week passed. Mention was made of the review of the ALA Endowment investments.

Much discussion was held at ALA regarding the Outsourcing Task Force report.

\section{SELA Councilor}

There was no report from the councilor. However, discussion was held regarding continued membership in SELA. Nominees for the position of SELA councilor have been notified that the position could possibly be abolished. NCLA has already paid SELA dues for 1999. It was decided that our SELA councilor will help determine the long-term viability of the organization and report back to the NCLA board at the April 2000 Executive Board meeting. Withdrawal from SELA will take a by-law change. It was also suggested that NCLA invite the president of SELA to the Biennial Conference.

\section{North Carolina State Library}

Commission

There was no report.

\section{Old business}

The July Executive Board Meeting will be held July 30 over the Web. Reports are to be submitted to the Web site 2 weeks prior to the meeting.

A suggestion was made to restructure the meeting agenda, placing items that require Board action at the beginning of the meeting. President Gass will investigate this idea.

The meeting was adjourned at 2:20 PM. - Respectfully submitted, Liz Jackson Secretary 


\section{North Carolina Library Association 1997-1999 Executive Board}

\section{PRESIDENT}

Beverley Gass

M.W. Bell Library

Guilford Technical College

P.O. Box 309

Jamestown NC 27282-0309

Telephone: $336 / 334-4822$ x 2434

Fax: $\quad 336 / 841-4350$

GASSB@GTCC.CC.NC.US

VICE PRESIDENT/

PRESIDENT ELECT

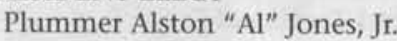

Catawba College

2300 W. Innes Street

Salisbury, NC 28144

Telephone: $\quad 704 / 637-4449$

Fax: $\quad 704 / 637-4304$

PAJONES@CATAWBA.EDU

\section{SECRETARY}

Elizabeth J. Jackson

West Lake Elementary Schoo

207 Glen Bonnie Lane

Apex, NC 27511

Telephone: $919 / 380-8232$

Fax: $\quad$ 919/662-2313

LIZ@WLE.APEX.K12.NC.US

\section{TREASURER}

Diane D. Kester

East Carolina University

105 Longview Drive

Goldsboro, NC 27534-8871

Telephone: 919/328-6621

Fax: $\quad 919 / 328-4638$

KESTERD@EMAIL.ECU.EDU

\section{DIRECTORS}

Vanessa Work Ramseur

Hickory Grove

7209 E. W.T. Harris Blvd.

Charlotte, NC 28227

Telephone: 704/563-9418

Fax: $\quad 704 / 568-2686$

VWR@PLCMC.LIB.NC.US

Ross Holt

Randolph Public Library

201 Worth Street

Asheboro, NC 27203

Telephone: $336 / 318-6806$

Fax: $\quad 336 / 318-6823$

RHOLT@NCSL.DCR.STATE.NC.US

\section{ALA COUNCILOR}

Jacqueline B. Beach

Craven-Pamlico-Carteret

Regional Library

400 Johnson

New Bern, NC 28560

Telephone: $\quad 919 / 823-1141$

Fax: $\quad 919 / 638-7817$

JBEACH@NCSL.DCR.STATE.NC.US
SELA REPRESENTATIVE

(election pending)

EDITOR, North Carolina Libraries Frances Bryant Bradburn

Educational Technologies

NC Dept. of Public Instruction

301 N. Wilmington Street

Raleigh, NC 27601-2825

Telephone: 919/715-1528

Fax: $\quad 919 / 733-4762$

FBRADBUR@DPI.STATE.NC.US

PAST-PRESIDENT

David Fergusson

Forsyth County Public Library

660 W. Fifth Street

Winston-Salem NC 27101

Telephone: $336 / 727-2556$

Fax: $\quad 336 / 727-2549$

D_FERGUSSON@RORSYTHLIB.NCUS

ADMINISTRATIVE ASSISTANT

Maureen Costello

North Carolina Library Association

c/o State Library of North Carolina

4646 Mail Service Center

Raleigh, NC 27699-4646

Telephone: 919/839-6252

Fax: $\quad$ 919/839-6252

MCOSTEHOQNCSL.DCRSTATENCUS

\section{SECTION CHAIRS}

CHILDREN'S SERVICES SECTION

Susan Adams

Southeast Regional Library

9087 th Avenue

Garner, NC 27529

Telephone: 919/662-6635

Fax: $\quad 919 / 662-2270$

SADAMS@CO.WAKE.NC.US

COLLEGE AND UNIVERSITY SECTION

Shirley Gregory

Hackney Library, Barton College

Box 5000

Wilson, NC 28893-7000

Telephone: 252/366-6501

Fax: $\quad 252 / 399-6571$

SGREGORY@BARTON.EDU

COMMUNITY AND JUNIOR

COLLEGE SECTION

Martha E. Davis

Davidson Co. Comm. College

P. O. Box 1287

Lexington, NC 27293-1287

Telephone: $\quad 336 / 249-8186$

Fax: $\quad 336 / 248-8531$

MDAVIS@DAVIDSON.CC.NC.US
DOCUMENTS SECTION

Ann Miller

Perkins Library

Duke University

Durham, NC 27708-0177

Telephone: 919/660-5855

Fax: $\quad$ 919/660-2855

AEM@MAIL.LIB.DUKE.EDU

LIBRARY ADMINISTRATION AND

MANAGEMENT SECTION

Rhoda Channing

Z. Smith Reynolds Library

Box 7777

Wake Forest University

Winston-Salem, NC 27109-7777

Telephone: 336/759-5090

Fax: $\quad 336 / 759-9831$

CHANNING@WFU.EDU

NORTH CAROLINA ASSOCIATION

OF SCHOOL LIBRARIANS

Malinda Ratchford

Gaston County Schools

366 W. Garrison Blvd.

Gastonia, NC 28052

Telephone: 704/866-6251

Fax: 704/866-6194

MELEIS@AOL.COM

NORTH CAROLINA PUBLIC

LIBRARY TRUSTEES ASSOCIATION

Peter Keber

Public Library of Charlotte/

Mecklenburg County

310 North Tryon Street

Charlotte, NC 28202

Telephone: 704/386-5086

Fax: $\quad 704 / 386-6444$

PK@PLCMC.LIB.NC.US

PUBLIC LIBRARY SECTION

Steve Sumerford

Glenwood Branch Library

1901 W. Florida Street

Greensboro, NC 27403

Telephone: $336 / 297-5002$

Fax: $\quad 336 / 297-5005$

GLENWOOD@NR.INFI.NET

REFERENCE AND ADULT SERVICES

Carolyn Price

Forsyth County Public Library

660 W. Fifth Street

Winston-Salem, NC 27101

Telephone: $\quad 336 / 727-8456$

Fax: $\quad 336 / 727-2549$

C_PRICE@FORSYTH.LIB.NC.US

RESOURCES AND TECHNICAL

SERVICES SECTION

Ginny Gilbert

Perkins Library

Duke University

230C Box 90191

Durham, NC 27708

Telephone: $\quad 919 / 660-5815$

Fax: $\quad$ 919/684-2855

VAG@MAIL.LIB.DUKE.EDU
ROUND TABLE CHAIRS

NEW MEMBERS ROUND TABLE

Tracy Babiasz

Durham County Library

300 N. Roxboro Street

PO Box 3809

Durham, NC 27702-3809

Telephone: $919 / 560-0191$

Fax: $\quad$ 919/560-0137

TBABIASZ@NCSL.DCRSTATE.NC.US

NORTH CAROLINA LIBRARY

PARAPROFESSIONAL ASSOCIATION

Frances Lampley

Southeast Regional Library

908 7th Street

Garner, NC 27259

Telephone: 919/662-2262

Fax: $\quad 919 / 662-2270$

FLAMPLEY@CO.WAKE.NC.US

ROUND TABLE FOR ETHNIC

MINORITY CONCERNS

Barbara Best-Nichols

Reichold Chemicals, Inc.

6124 Yellowstone Drive

Durham, NC 27713-9708

Telephone: 919/990-8054

Fax: $\quad 919 / 990-7859$

BARBARA.BEST-NICHOLS

@REICHHOLD.COM

ROUND TABLE ON SPECIAL

COLLECTIONS

Maury York

Joyner Library

East Carolina University

Greenville, NC 27858

Telephone: 252/328-6601

YORKM@MAIL.ECU.EDU

ROUND TABLE ON THE STATUS OF WOMEN IN LIBRARIANSHIP

Marilyn Miller

4103 Friendly Avenue

Greensboro, NC 27410

Telephone: $\quad 336 / 299-8659$

Fax: $\quad 336 / 334-5060$

M_MILLER@HAMLET.UNCG.EDU

TECHNOLOGY AND TRENDS

ROUND TABLE

Eleanor I. Cook

Belk Library

Appalachian State University

Boone, NC 28606

Telephone: $828 / 262-2786$

Fax: $\quad 828 / 262-2773$

COOKEI@APPSTATE.EDU

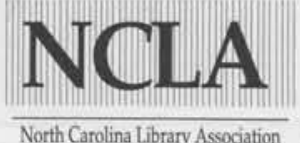


Editor

FRANCES BRYANT BRADBURN

Educational Technologies

NC Dept. of Public Instruction $301 \mathrm{~N}$. Wilmington Street Raleigh, NC 27601-2825

(919) 715-1528

(919) 733-4762 (FAX)

fbradbur@dpi.state.nc.us

Associate Editor

ROSE SIMON

Dale H. Gramley Library

Salem College

Winston-Salem, NC 27108

(336) 917-5421

simon@salem.edu

\section{Associate Editor}

JOHN WELCH

State Library of North Carolina

4640 Mail Service Center

Raleigh, NC 27699-4640

(919) $733-2570$

jwelch@library.dcr.state.nc.us

\section{Book Review Editor}

DOROTHY DAVIS HODDER

New Hanover Co. Public Library

201 Chestnut Street

Wilmington, NC 28401

(910) $772-7858$

dhodder@co.new-hanover.nc.us

Lagniappe Editor

PLUMMER ALSTON JONES, JR.

Corriher-Linn-Black Library

Catawba College

2300 W. Innes Street

Salisbury, NC 28144

(704) 637-4449

pajones@catawba.edu

Indexer

MICHAEL COTTER

Joyner Library

East Carolina University

Greenville, NC 27858-4353

(252) 328-0237

cottermi@mail.ecu.edu

Advertising Manager

HARRY TUCHMAYER

New Hanover Co. Public Library

201 Chestnut Street

Wilmington, NC 28401

(910) $772-7857$

htuchmayer@co.new-hanover.nc.us

Between Us Editor

KEVIN CHERRY

Rowan Public Library

P.O. Box 4039

Salisbury, NC 28145-4039

(704) 638-3021

cherryk@co.rowan.nc.us
Children's Services

MELVIN K. BURTON

Public Library of Charlotte \& Mecklenburg

North County Regional Library

16500 Holly Crest Lane

Huntersville, NC 28078

(704) 895-8178

mburton@plcmc.lib.nc.us

College and University

ARTEMIS KARES

Joyner Library

East Carolina University

Greenville, NC 27858-4353

(252) 328-2263

karesa@mail.ecu.edu

Community and Junior College

LISA C. DRIVER

Pitt Community College

PO Drawer 7007

Greenville, NC 27835-7007

(252) $321-4357$

Idriver@pcc.pitt.cc.nc.us

Documents

MICHAEL VAN FOSSEN

Reference Documents

Davis Library CB \#3912

University of North Carolina

Chapel Hill, NC 27599

(919) 962-1151

mike_vanfossen@unc.edu

Library Administration and

Management Section

JOLINE EZZELL

Perkins Library

Duke University

Durham, NC 27708-0175

(919) 660-5925

joline.ezzell@duke.edu

New Members Round Table RHONDA FLORENCE

Florence Elementary School

High Point, NC 27265

(336) $819-2120$

rholbroo@guilford.k12.nc.us

N.C. Asso. of School Librarians

DIANE KESSLER

Durham Public Schools

808 Bacon St.

Durham, NC 27703

(919) $560-2360$

kesslerd@bacon.durham.k12.nc.us

\section{North Carolina Library}

Paraprofessional Association

SHARON NOLES

Southeast Regional Library in Garner

9087 th Avenue

Garner, NC 27529

(919) 894-8322

snoles@co.wake.nc.us
Public Library Section

JOHN ZIKA

Person County Public Library

319 S. Main St.

Roxboro, NC 27573

(336) $597-7881$

jzika@ncsl.dcr.state.nc.us

Reference/Adult Services

SUZANNE WISE

Belk Library

Appalachian State University

Boone, NC 28608

(828) 262-2798

wisems@appstate.edu

Resources and Technical Services

PAGE LIFE

Davis Library CB\#3914

UNC-Chapel Hill

Chapel Hill, NC 27514-8890

(919) 962-0153

page_life@unc.edu

Round Table for Ethnic Minority Concerns BRIGITTE BLANTON

Greensboro Public Library

PO Box 3178

Greensboro, NC 27402-3178

(336) $373-2716$

ncs0921@interpath.com

Round Table on Special Collections MEGAN MULDER

Wake Forest University Library

PO Box 7777 Reynolda Station

Winston-Salem, NC 27109-7777

(336) 758-5091

mulder@wfu.edu

Round Table on the Status of Women

in Librarianship

JOAN SHERIF

Northwestern Regional Library

111 North Front Street

Elkin, NC 28621

(336) 835-4894

jsherif@ncsl.dcr.state.nc.us

Technology and Trends

DIANE KESTER

Library Studies and Ed. Technology

East Carolina University

Greenville, NC 27858-4353

(252) 328-4389

1sddkest@eastnet.educ.ecu.edu

Wired to the World Editor

RALPH LEE SCOTT

Joyner Library

East Carolina University

Greenville, NC 27858-4353

(252) 328-0235

scottr@mail.ecu.edu

Trustees

ANNE B. WILGUS

N.C. Wesleyan College

Rocky Mount, NC 27804

(252) 442-2662

(252) 977-3701 (FAX) 


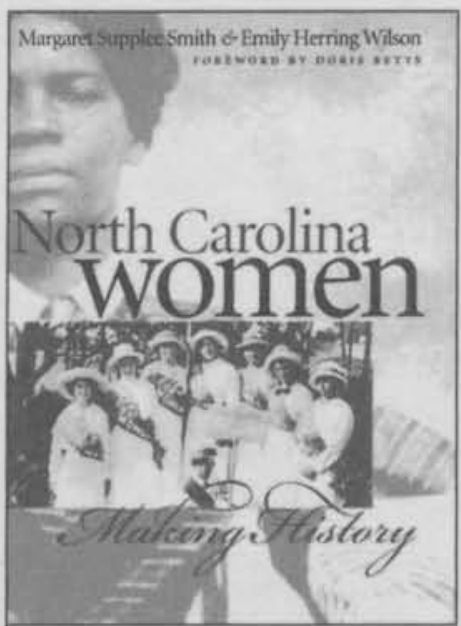

North Carolina Women

Making History

MARGARET SUPPLEE SMITH

AND EMILY HERRING WILSON

Foreword by Doris Betts

The only book that charts the influence of women on the state's economy and character.

"This readable and carefully researched history is a joyful circumstance for all readers, who will realize anew how much better our shared future becomes when we learn from the shared past." -Doris Betts, from the Foreword $8.5 \times 11,12$ color $/ 238$ b 2 willus. (0-8078-2463-1) Apr $\$ 29.95$ eloth

\section{now back in print! \\ Mary}

An Autobiography

MARY E. MEBANE

"A painful, funny, romantic, tragic, intensely personal account of a young black woman coming of age in the back country of North Carolina."

- Harrison E. Salisbury

(0-8078-4821-2) Mar $\$ 16.50$ paper

A Chapel Hill Book

\section{Mary, Wayfarer}

An Autobiography

MARY E. MEBANE

Mary moves on: acquires a Ph.D., becomes a participant in the Black freeedom struggle, and discovers what she calls "the gulf stream" of her life-writing.

(0-8078-4822-0) Mar $\$ 17.95$ paper A Chapel Hill Book

\section{The Outer Banks}

ANTHONY BAILEY

The memorable coastal adventures of a

British travel writer.

(0-8078-4820-4) Apr $\$ 16.95$ paper

A Chapel Hill Book

\section{Teach's Light}

A Tale of Blackbeard the Pirate NELL WISE WECHTER

This popular time-travel fantasy reveals the story of Blackbeard the Pirate. For young adults.

(0-8078-4793-3) May $\$ 9.95$ paper

A Chapel Hill Book

\title{
NORTH CAROLINA
} SPRING 1999

Sherman's Civil War

Selected Correspondence of William T. Sherman, 1860-1865 BROOKS D. SIMPSON

AND JEAN V. BERLIN, EDS.

The long-awaited edition of Sherman's wartime correspondence includes more than 400 personal and official letters. (0-8078-2440-2) May $\$ 45$ eloth Civil War America

\section{Iron Confederacies}

Southern Railways, Klan Violence, and Reconstruction

SCOTT REYNOLDS NELSON

Uses the history of southern railways to explore states' rights, racial violence, labor strife, and big business during

Reconstruction.

(0-8078-2476-3) May $\$ 39.95$ eloth (0-8078-4803-4) May $\$ 18.95$ paper

\section{Hiring the Black Worker}

The Racial Integration of the Southern Textile Industry, 1960-1980

TIMOTHY J. MINCHIN

Based on oral history interviews and

never-before-used legal records, this

book reveals how African American men

and women fought to integrate the

South's largest industry.

(0-8078-2470-4) May $\$ 49.95$ eloth

(0-8078-4771-2) May $\$ 19.95$ paper

back in print in paperback

\section{One of Lee's Best Men}

The Civil War Letters of

General William Dorsey Pender

WILLIAM W. HASSLER, ED.

NEW FOREWORD BY BRIAN WILLS

"Pender's letters to his wife provide a moving human document recording the response of a young, talented, sensitive officer to his war experiences." -Choice

(0-8078-4823-9) Apr \$16.95 paper

\section{new in paperback}

\section{Catesby's Birds of}

\section{Colonial America}

ALAN FEDUCCIA, ED.

Foreword by Russell W. Peterson

"Reproduces [Catesby's] complete text plus all his bird paintings and many of the plants. ... Highly recommended." -Library Journal

"Before Audubon, there was Mark Catesby." -Roger Caras, president of the ASPCA

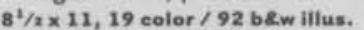

(0-8078-4816-6) Feb 324.95 paper

Fred W. Morrison Series in Southern Studies

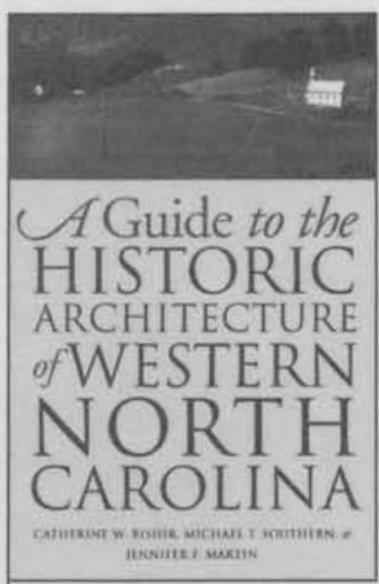

\section{A Guide to the Historic Architecture of Western North Carolina}

CATHERINE W. BISHIR, MICHAELT. SOUTHERN, AND JENNIFER F. MARTIN From log farmsteads to hydro-electric dams, this book includes 1,200 sites in the 25 counties of the foothilis and mountains. "An indispensable volume for resident and tourist alike, [it] is also great fun simply to read!"-Fred Chappell

313 photos, 30 maps

(0-8078-2465-8) Apr $\$ 34.95$ eloth

(0-8078-4767-4) Apr \$19.95 paper

Richard Hampton Jenrette Series in Architecture and the Decorative Arts

\section{Blue Ridge 2020}

An Owner's Manual

STEVE NASH

"A book that needed to be written if we are to have the public awareness that will cause us to do the right things to perpetuate the beauty and charm of the mountains."-Hugh Morton 8 color $/ 22$ b2w illus.

(0-8078-4759-3) Mar $\$ 19.95$ paper

\section{Empire's Nature}

Mark Catesby's New World Vision AMY R. W. MEYERS AND MARGARET BECK PRITCHARD, EDS.

Interdisciplinary essays reveal Catesby's important influence on the development of art, natural history, and scientific observation in the 18th century.

16 color $/ 42$ bswillus.

$(0-8078-2459-3)$ Mar $\$ 60$ eloth (0-8078-4762-3) Mar \$24.95 paper

Published for the Omohundro Institute of Early American History \& Culture, Williamsburg, Va.

call for a free catalog!

\section{The University of North Carolina Press}

\author{
phone [800] 848.6224. fax [800] 272.6817
}

chapel hill - www.uncpress.unc.edu 


\section{Upcoming Issues}

Fall 1999 Life and Limb: Security Issues

Page Life, Guest Editor

Winter 1999 Conference Issue

Spring 2000 Back to the Future: Digitization of Resources David Ferriero, Guest Editor

Summer 2000 Preserving Local History

Plummer Alston Jones, Jr. and Thomas Kevin B. Cherry, Guest Editors

Fall 2000 Research and Librarianship

Winter 2000 The Call of Story

Unsolicited articles dealing with the above themes or any issue of interest to North Carolina librarians are welcomed. Please contact the editor for manuscript guidelines and deadlines.

Norit Carolina Libraries, published four times a year, is the official publication of the North Carolina Library Association. Membership dues include a subscription to Norit Carolina Libraries. Membership information may be obtained from the Administrative Assistant of NCLA. Subscription rates are $\$ 32.00$ per year, or $\$ 10.00$ per issue, for domestic subscriptions; $\$ 50.00$ per year, or $\$ 15.00$ per issue, for foreign subscriptions. Backfiles are maintained by the editor. Microfilm copies are available through University Microfilms. Norit Carolina Libraries is indexed by Library Literature and publishes its own annual index. 